MAR 71960

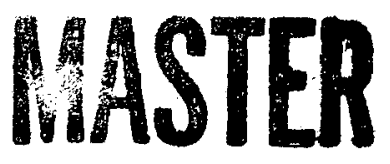

TECHNICAL REPORTS SERIES No. 79

\title{
The Plutonium-0xygen and
}

\section{Uranium-Plutonium-Oxygen Systems:}

\section{A Thermochemical Assessment}




\section{DISCLAIMER}

This report was prepared as an account of work sponsored by an agency of the United States Government. Neither the United States Government nor any agency Thereof, nor any of their employees, makes any warranty, express or implied, or assumes any legal liability or responsibility for the accuracy, completeness, or usefulness of any information, apparatus, product, or process disclosed, or represents that its use would not infringe privately owned rights. Reference herein to any specific commercial product, process, or service by trade name, trademark, manufacturer, or otherwise does not necessarily constitute or imply its endorsement, recommendation, or favoring by the United States Government or any agency thereof. The views and opinions of authors expressed herein do not necessarily state or reflect those of the United States Government or any agency thereof. 


\section{DISCLAIMER}

Portions of this document may be illegible in electronic image products. Images are produced from the best available original document. 

THE PLUTONIUM-OXYGEN

AND URANIUM-PLUTONIUM-OXYGEN SYSTEMS:

A THERMOCHEMICAL ASSESSMENT 
The following States are Members of the International Atomic Energy Agency:

AFGHANISTAN
ALBANIA
ALGERIA
ARGENTINA
AUSTRALIA
AUSTRIA
BELGIUM
BOLIVIA
BRAZIL
BULGARIA
BURMA
BYELORUSSIAN SOVIET
SOCIALIST REPUBLIC
CAMBODIA
CAMEROON
CANADA
CEYLON
CHILE
CHINA
COLOMBIA
CONGO, DEMOCRATIC
REPUBLIC OF
COSTA RICA
CUBA
CYPRUS
CZECHOSLOVAK SOCIALIST
REPUBLIC
DENMARK
DOMINICAN REPUBLIC
ECUADOR
EL SALVADOR
ETHIOPIA
FINLAND
FRANCE
GABON

GERMANY, FEDERAL
REPUBLIC OF
GHANA
GREECE
GUATEMALA
HAITI
HOLY SEE
HUNGARY
ICELAND
INDIA
INDONESIA
IRAN
IRAQ
ISRAEL
ITALY
IVORY COAST
JAMAICA
JAPAN
JORDAN
KENYA
KOREA, REPUBLIC OF
KUWAIT
LEBANON
LIBERIA
LIBYA
LUXEMBOURG
MADAGASCAR
MALI
MEXICO
MONACO
MOROCCO
NETHERLANDS
NEW ZEALAND
NICARAGUA
NIGERIA

\author{
NORWAY \\ PAKISTAN \\ PANAMA \\ PARAGUAY \\ PERU \\ PHILIPPINES \\ POLAND \\ PORTUGAL \\ ROMANIA \\ SAUDI ARABIA \\ SENEGAL \\ SIERRA LEONE \\ SINGAPORE \\ SOUTH AFRICA \\ SPAIN \\ SUDAN \\ SWEDEN \\ SWITZERLAND \\ SYRIAN ARAB REPUBLIC \\ THAILAND \\ TUNISIA \\ TURKEY \\ UGANDA \\ UKRAINIAN SOVIET SOCIALIST \\ REPUBLIC \\ UNION OF SOVIET SOCIALIST \\ REPUBLICS \\ UNITED ARAB REPUBLIC \\ UNITED KINGDOM OF GREAT \\ BRITAIN AND NORTHERN \\ IRELAND \\ UNITED STATES OF AMERICA \\ URUGUAY \\ VENEZUELA \\ VIET-NAM \\ YUGOSLA VIA
}

The Agency's Statute was approved on 23 October 1956 by the Conference on the Statute of the IAEA held at United Nations Headquarters, New York; it entered into force on 29 July 1957. The Headquarters of the Agency are situated in Vienna. Its principal objective is "to accelerate and enlarge the contribution of atomic energy to peace, health and prosperity throughout the world". 
TECHNICAL REPORTS SERIES No. 79

\title{
THE PLUTONIUM-OXYGEN AND URANIUM-PLUTONIUM-OXYGEN SYSTEMS:
}

\section{A THERMOCHEMICAL ASSESSMENT}

\author{
REPORT OF A PANEL ON THERMODYNAMICS \\ OF PLUTONIUM OXIDES
}

HELD IN VIENNA, 24-28 OCTOBER 1966

INTERNATIONAL ATOMIC ENERGY AGENCY VIENNA, 1967 
THE PLUTONIUM-OXYGEN AND URANIUM-PLUTONIUM-OXYGEN SYSTEMS: A THERMOCHEMICAL ASSESSMENT

(Technical Reports Series, No.79)

ABSTRACT. The report of a panel of experts convened by the IAEA in Vienna in March 1964. It reviews the structural and thermodynamic data for the $\mathrm{Pu}-\mathrm{O}$ and $\mathrm{U}-\mathrm{Pu}-\mathrm{O}$ systems and presents the conclusions of the panel.

Contents: Introduction; Plutonium oxides: The uranium-plutonium-oxygen system; Other $\mathrm{PuO}_{2}-\mathrm{MeO}_{\mathbf{x}}$ oxide systems; References.

Entirely in English.

(86 pp., $16 \times 24 \mathrm{~cm}$, paper-bound, 27 figures)

(1967)

Price: US $\$ 2.00 ; 14 / 2 \mathrm{stg}$. 


\section{FOREWORD}

With the development of advanced types of reactors, plutonium and its compounds have gained importance as nuclear fuels. In view of this growing interest and the need to collect and assess the fundamental data, the International Atomic Energy Agency convened a panel on Thermodynamics of Plutonium Oxides from 24 to 28 October, 1966. The purpose of the panel, which met at the Agency's headquarters in Vienna, was to evaluate critically the thermodynamic data at present available on plutonium oxides and mixed oxides from the viewpoint of nuclear technology.

In the process of this assessment, the work of the panel revealed in what areas more dependable information is needed and more work should be undertaken. The present report, which is the outcome of the panel meeting, presents a set of the most reliable data now available. 


\section{CONTENTS}

I. INTRODUCTION $\ldots \ldots \ldots \ldots \ldots \ldots \ldots \ldots \ldots \ldots \ldots \ldots$

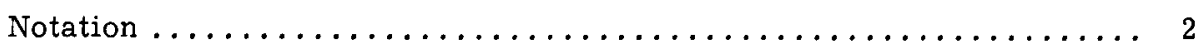

II. PlutoniUm OXIDES $\ldots \ldots \ldots \ldots \ldots \ldots \ldots \ldots \ldots \ldots \ldots$

1. Preparation $\ldots \ldots \ldots \ldots \ldots \ldots \ldots \ldots \ldots \ldots \ldots \ldots \ldots \ldots \ldots \ldots \ldots \ldots \ldots \ldots$

1.1. Plutonium monoxide ................... 3

1.2. Hexagonal $\mathrm{Pu}_{2} \mathrm{O}_{3} \ldots \ldots \ldots \ldots \ldots \ldots \ldots \ldots \ldots \ldots \ldots \ldots, \ldots \ldots \ldots$

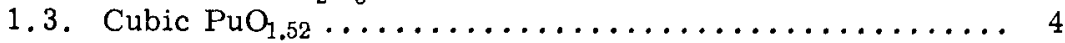

1.4. $\mathrm{PuO}_{1.61}$ and non-stoichiometric oxides $\ldots \ldots \ldots \ldots \ldots, 5$

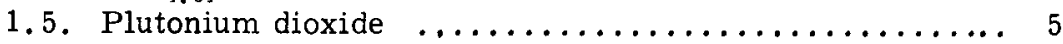

1.6. Higher oxides of plutonium $\ldots \ldots \ldots \ldots \ldots \ldots \ldots \ldots \ldots$

2. Phase diagram $\ldots \ldots \ldots \ldots \ldots \ldots \ldots \ldots \ldots \ldots \ldots \ldots \ldots$

2.1. Crystal structures $\ldots \ldots \ldots \ldots \ldots \ldots \ldots \ldots \ldots \ldots$

2.2. Condensed phase diagram $\ldots \ldots \ldots \ldots \ldots \ldots \ldots \ldots \ldots$

3. Thermochemical data for solid phases $\ldots \ldots \ldots \ldots \ldots \ldots \ldots 21$

3.1. Heat capacities and entropies $\ldots \ldots \ldots \ldots \ldots \ldots \ldots \ldots \ldots \ldots$

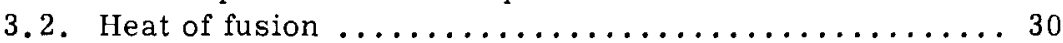

3.3. Calorimetric heats of formation $\ldots \ldots \ldots \ldots \ldots \ldots \ldots 30$

3.4. High-temperature equilibria ............... 30

3.5. Integration of partial molar quantities $\ldots \ldots \ldots \ldots \ldots 34$

3.6. Tabulation of thermochemical data ............40

4. Vaporization behaviour .....................41

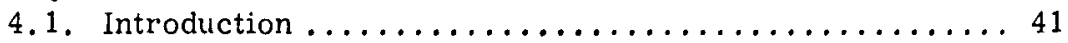

4.2. Resumé of experimental data and thermodynamic

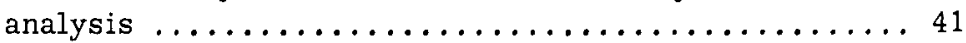

4.3. Intercomparison of the plutonium- and uranium-

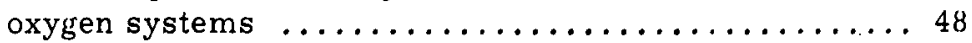

5. Conclusions and future work $\ldots \ldots \ldots \ldots \ldots \ldots \ldots \ldots$

III. THE URANIUM-PLUTONIUM-OXYGEN SYSTEM $\ldots \ldots \ldots \ldots \ldots 52$

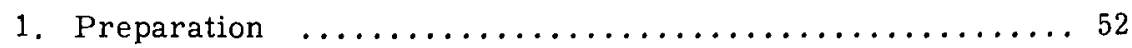

1.1. Preparation of closely stoichiometric solid solutions

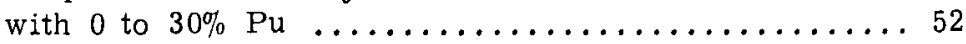

1.2. Preparation of other compositions $\ldots \ldots \ldots \ldots \ldots \ldots \ldots 52$

1.3. Analysis ........................... 53 


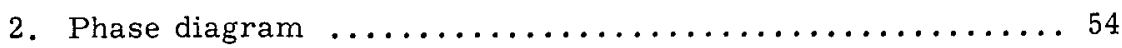

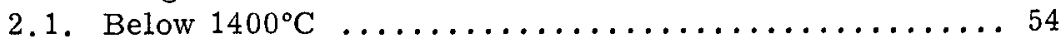

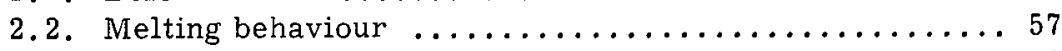

2.3. The U-Pu-O phase diagram ............... 58

3. Thermodynamic properties ................... 59

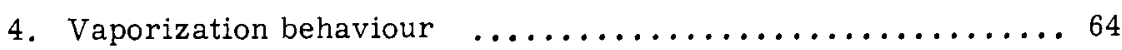

5. Conclusions and future work $\ldots \ldots \ldots \ldots \ldots \ldots \ldots \ldots 6$

IV. OTHER $\mathrm{PuO}_{2}-\mathrm{MeO}_{\mathrm{x}}$ OXIDE SYSTEMS $\ldots \ldots \ldots \ldots \ldots \ldots \ldots \ldots$

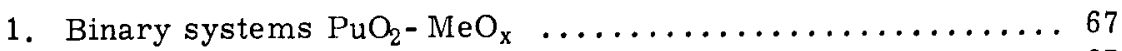

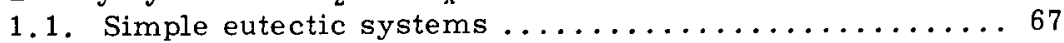

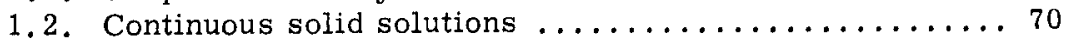

1.3. More complicated systems .............. 77

2. Ternary and quaternary plutonium-metal-oxides ........ 77

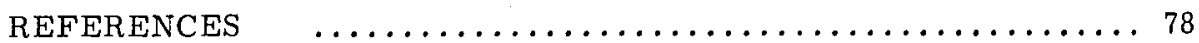

LIST OF PARTICIPANTS $\ldots \ldots \ldots \ldots \ldots \ldots \ldots \ldots \ldots \ldots \ldots \ldots$

REPORTS SUBMITTED TO THE PANEL $\ldots \ldots \ldots \ldots \ldots \ldots \ldots \ldots$ 


\section{INTRODUCTION}

The favourable physical properties of uranium dioxide (for example, high melting point, stability under irradiation) have led to its use as a fuel in various types of nuclear reactors. With the increasing installation of thermal reactors for the commercial generation of electricity, large quantities of plutonium will become available, and it will be very attractive to use this in fast breeder reactors. A strong candidate for the fuel of such a reactor is a mixed uranium-plutonium dioxide.

A knowledge of the thermodynamic properties of fuel materials is important in the control of the stoichiometry during fabrication so necessary in a nuclear fuel element, and in predicting the possible behaviour under operating conditions (including compatibility, migration of fuel down a temperature gradient by vaporization, and valency state of fission products).

The thermodynamic properties of the complex uranium dioxide phase were discussed at a panel organized by the International Atomic Energy Agency [1] in March 1964, and it was considered valuable to compile a similar critical assessment of the thermochemical behaviour of plutoniumoxygen and uranium-plutonium-oxygen systems. The present report is a summary of the data available to the panel and the conclusions reached.

The fluorite structure in which the dioxides crystallize has a remarkable capacity for withstanding both the addition and removal of oxygen ions, so that wide homogeneity ranges of general formula $\mathrm{MO}_{2 \pm \mathrm{x}}$ are formed at high temperatures in both the binary systems (except for $\mathrm{PuO}_{2+x}$ ) and in the ternary $\mathrm{U}-\mathrm{Pu}-\mathrm{O}$ system. These wide deviations from stoichiometry make the measurement of almost all physical properties unusually difficult, and also have wide repercussions on the use of the oxides as fuel materials.

In recent years, a start has been made on the correlation of the various physical properties of $\mathrm{UO}_{2+x}$ with a single defect model, and similar calculations on the substoichiometric phases would be most valuable. It is to be hoped that this review of the structural and thermodynamic data for the $\mathrm{Pu}-\mathrm{O}$ and $\mathrm{Pu}-\mathrm{U}-\mathrm{O}$ systems will stimulate further research in this and other aspects of the behaviour of this fascinating class of compounds. 


\section{NOTATION}

Symbol

$\mathrm{a}$
$\mathrm{C}_{\mathrm{p}}$
$\Delta \mathrm{G}$
$\Delta \overline{\mathrm{G}}_{\mathrm{O}_{2}}$
$\Delta \mathrm{H}$
$\Delta \mathrm{H}_{\mathrm{f}}^{0}$
$\Delta \overline{\mathrm{H}}_{\mathrm{O}_{2}}$

$\ln$

$\log$

$\mathrm{p}$

$\mathrm{R}$

$\mathrm{S}_{298}^{0}$

$\triangle \mathrm{S}$

$\Delta \overline{\mathrm{S}}_{0_{2}}$

$\mathrm{T}$

$<>$

\{\}

( )

[ ]
Meaning

Activity

Molar heat capacity

Free energy of reaction

Partial molar-free energy of solution of 1 mole of $\mathrm{O}_{2}$

Heat of reaction

Heat of formation at $25^{\circ} \mathrm{C}$

Partial molar heat of solution of 1 mole of $\mathrm{O}_{2}$

$\log _{e}$

$\log _{10}$

Pressure

Gas constant

Standard entropy at $25^{\circ} \mathrm{C}$

Entropy of reaction

Partial molar entropy of solution of 1 mole of $\mathrm{O}_{2}$

Absolute temperature

Solid state

Liquid state

Gaseous state

Dissolved state (suffix denoting solvent)

\section{Common units}

cal degK ${ }^{-1} \mathrm{~mole}^{-1}$

cal

cal mole -1

cal

cal

cal mole $\mathrm{e}^{-1}$ atm

$1.987 \mathrm{cal} \mathrm{degK}^{-1} \mathrm{~mole}^{-1}$ cal degK $\mathrm{mole}^{-1}$ (e.u.) cal $\operatorname{degK}^{-1}$ cal degK mole $^{-1}$ 


\section{PLUTONIUM OXIDES}

\section{PREPARATION}

\subsection{Plutonium monoxide}

Although plutonium monoxide, $\mathrm{PuO}$, was reported by Mooney and Zachariasen [2] as an impurity phase, and X-ray diffraction patterns attributed to PuO have been described [3], pure bulk samples have not been prepared. PuO is generally seen as a surface film on plutonium metal. The formation of $\mathrm{PuO}$ by reduction of pure samples of $\mathrm{PuOCl}$ and $\mathrm{PuO}_{2}$ by barium vapour has been reported by Westrum [4], but chemical evidence for its formation is meagre. Metallographic and X-ray examination [5] of heat-treated and quenched samples of $\mathrm{PuO}_{2}+\mathrm{Pu}$ in the composition range where $\mathrm{PuO}$ would be expected to be formed indicated the presence of mixtures only of hexagonal $\mathrm{Pu}_{2} \mathrm{O}_{3}$ and plutonium.

Akimoto [6] reported the preparation of $\mathrm{PuO}$ by direct reaction between molten plutonium and oxygen generated by the thermal decomposition of $\mathrm{Ag}_{2} \mathrm{O}$. Powder patterns of the product indicated a face-centred cubic phase with a lattice parameter that agreed with the value reported by $\mathrm{Zachariasen}$. The preparation of $\mathrm{PuO}$ by the reduction of $\mathrm{PuO}_{2}$ at $1800^{\circ} \mathrm{C}$ by carbon was reported by Skavdahl [7]. However, more recent experiments of Forbes et al. [8] have indicated that the products always contained carbon. Other attempts to prepare the monoxide [9] have failed and recent work on the $\mathrm{Pu}-\mathrm{C}$-O ternary phase diagram $[10,11,12]$ has shown conclusively that the oxygen-rich limit of the $\mathrm{Pu}(\mathrm{O}, \mathrm{C})$ phase lies at approximately $\mathrm{PuC}_{0.3} \mathrm{O}_{0.7}$.

The reported preparation of the solid monoxide thus apparently refers to a material stabilized by impurity or by surface energy. However, $\mathrm{PuO}$ (gas) is almost certainly the major species over plutonium oxides near the sesquioxide composition (see Section II. 4).

\subsection{Hexagonal $\mathrm{Pu}_{2} \mathrm{O}_{3}$}

Hexagonal plutonium sesquioxide, referred to in the previous literature as $\beta-\mathrm{Pu}_{2} \mathrm{O}_{3}$, is a definite phase with the type a rare earth sesquioxide structure. An upper oxygen content corresponding to $\mathrm{PuO}_{1.510}$ has been suggested [13]. In general, plutonium dioxide may be reduced to hexagonal $\mathrm{Pu}_{2} \mathrm{O}_{3}$ by plutonium metal, very dry hydrogen or carbon.

Holley et al. [5] prepared hexagonal $\mathrm{Pu}_{2} \mathrm{O}_{3}$ by reducing pure $\mathrm{PuO}_{2}$ with approximately $20 \%$ excess of plutonium turnings or chips in a closed tantalum crucible at $1500^{\circ} \mathrm{C}$. The mixture was held at that temperature for $3 \mathrm{~h}$, at the end of which the excess plutonium metal was removed by 
evaporation from the opened crucible. The product was a black sintered mass. At higher reduction temperatures, large flat crystals of hexagonal $\mathrm{Pu}_{2} \mathrm{O}_{3}$ were produced. Gardner et al. [13] used a similar method of preparation by heating a mixture of pure $\mathrm{PuO}_{2}$ powder and $20 \%$ excess plutonium metal (prepared by the decomposition of plutonium hydride) in a thoria crucible at $1500^{\circ} \mathrm{C}$ for $3 \mathrm{~h}$ in a stream of purified dry hydrogen gas. Excess plutonium volatilized away from the oxide leaving pure hexagonal $\mathrm{Pu}_{2} \mathrm{O}_{3}$. Dean [9] has shown that the reduction of the $\mathrm{PuO}_{2}$ by Pu starts at $700^{\circ} \mathrm{C}$.

Appreciable reduction of plutonium dioxide to a lower oxide occurs on sintering $\mathrm{PuO}_{2}$ pellets in "dry" hydrogen gas at temperatures above $1500^{\circ} \mathrm{C}$, the precise composition reached being dependent on the sintering temperature and water content in the hydrogen $[14,15]$. Gardner et al. [13] reported complete reduction of $\mathrm{PuO}_{2}$ pellets to hexagonal $\mathrm{Pu}_{2} \mathrm{O}_{3}$ in dry hydrogen (purified by passage over heated titanium turnings at $600^{\circ} \mathrm{C}$ ) at $1550^{\circ} \mathrm{C}$, if further titanium turnings were present in the reduction furnace.

Roberts et al. [16] found that plutonium dioxide is unstable in contact with carbon at low ambient pressures of carbon monoxide and at temperatures above $1000^{\circ} \mathrm{C}$. Detailed investigations of Skavdahl $[7,17]$ and Dean [9] have shown that hexagonal $\mathrm{Pu}_{2} \mathrm{O}_{3}$ prepared by reduction of $\mathrm{PuO}_{2}$ with carbon may be contaminated with minor amounts of cubic $\mathrm{PuO}_{1.52}$. Essentially pure hexagonal $\mathrm{Pu}_{2} \mathrm{O}_{3}$ was obtained by heating stoichiometric proportions of $\mathrm{PuO}_{2}$ and carbon at $1800 \pm 50^{\circ} \mathrm{C}$ for $5 \frac{1}{2} \mathrm{~h}$ in a pure helium atmosphere. Similar preparation [8] with $\mathrm{PuO}_{2}+\mathrm{C}$ blended compacts at $1800^{\circ} \mathrm{C}$ for $1 \mathrm{~h}$ showed essentially single-phase hexagonal $\mathrm{Pu}_{2} \mathrm{O}_{3}$ with an impurity carbon content of $0.05 \%$.

Skavdahl and Chikalla [18] reported the preparation of hexagonal $\mathrm{Pu}_{2} \mathrm{O}_{3}$ on a large scale $(110 \mathrm{~g} \mathrm{Pu})$ by vacuum reduction sintering of $\mathrm{PuO}_{2}$ carbon compacts followed by inert gas arc melting. Reaction of $\mathrm{PuO}_{2}$ with a slight excess of carbon at $1650^{\circ} \mathrm{C}$ in vacuum produced a mixture of hexagonal $\mathrm{Pu}_{2} \mathrm{O}_{3}$ and a small amount of $\mathrm{Pu}(\mathrm{O}, \mathrm{C})$. The $\mathrm{Pu}(\mathrm{O}, \mathrm{C})$ phase, being much more volatile than hexagonal $\mathrm{Pu}_{2} \mathrm{O}_{3}$, could be removed by heating in vacuum. Final arc-melting of the product to form a dense product also contributed to further vaporization of any $\mathrm{Pu}(\mathrm{O}, \mathrm{C})$ impurity giving pure hexagonal $\mathrm{Pu}_{2} \mathrm{O}_{3}$. The product analysed $\mathrm{O} / \mathrm{Pu}=1.500 \pm 0.015$, with $175 \mathrm{ppm}$ carbon impurity and $93 \%$ theoretical density.

\subsection{Cubic $\mathrm{PuO}_{1.52}$}

Cubic plutonium sesquioxide, referred to in the previous literature as $\alpha-\mathrm{Pu}_{2} \mathrm{O}_{3}$, has not been prepared as a single-phase compound, since it is stable only below $300^{\circ} \mathrm{C}$, and hexagonal $\mathrm{Pu}_{2} \mathrm{O}_{3}$ once formed is difficult to transform to cubic $\mathrm{PuO}_{1.52}$. Moreover, the exact composition of this phase is not yet known; early reports [5] suggested compositions between $\mathrm{PuO}_{1.58}$ and $\mathrm{PuO}_{1.62}$, but the recent phase diagram studies [13] indicate a lower oxygen composition limit of $\mathrm{PuO}_{1.515}$.

Cubic $\mathrm{PuO}_{1.52}$ has been prepared in various two-phase mixtures. Thus heating $\mathrm{PuO}_{2}$ at 1650 to $1800^{\circ} \mathrm{C}$ in vacuum or in inert or reducing atmo- 
spheres results in partial reduction of the dioxide, and a mixture of cubic $\mathrm{PuO}_{1.52}$ and $\mathrm{PuO}_{1.98}$ is formed on cooling to room temperature. The proportion of cubic $\mathrm{PuO}_{1.52}$ varies from 10 to $40 \%$, depending on the temperature, duration of heating and the nature of the sintering atmosphere [19] . It has been reported [20] that when $\mathrm{PuO}_{2}$ is heated in helium to $2280^{\circ} \mathrm{C}$, dissociation and melting occur to give $\mathrm{PuO}_{1.61}$, which would disproportionate to give $\sim 80 \% \mathrm{PuO}_{1.52}$ at room temperature. However, reduction to this composition could not have occurred unless some strongly reducing constituent such as tantalum or carbon were also present.

Until the exact composition of this phase is known, it will be impossible to obtain single-phase material, but possible methods of preparation are controlled reduction of $\mathrm{PuO}_{2}$ by carbon or controlled oxidation of hexagonal $\mathrm{Pu}_{2} \mathrm{O}_{3}$. In any case, very prolonged annealing below $300^{\circ} \mathrm{C}$ will undoubtedly be necessary to remove the metastable, but enduring, hexagonal phase.

\section{4. $\mathrm{PuO}_{1,61}$ and non-stoichiometric oxides}

Oxides between $\mathrm{PuO}_{1.61}$ and $\mathrm{PuO}_{2}$ are mainly single-phase materials above $650^{\circ} \mathrm{C}$; these may be prepared by reduction of $\mathrm{PuO}_{2}$ with carbon [21] in vacuo, or less conveniently if a specified composition is required, hydrogen $[22,23]$, or for the higher compositions, by simply heating $\mathrm{PuO}_{2}$ in vacuo to high temperatures. Oxidation of a lower oxide by oxygen [13] or $\mathrm{PuO}_{2}$ may also be used. Some annealing may be required, but it should be remembered that prolonged heating in vacuo of any of these compounds will cause a change in composition because of incongruent vaporization (see Section II. 4).

\subsection{Plutonium dioxide}

Plutonium dioxide is the olive-to-brown product of the combustion of plutonium metal or practically any of its compounds (except those with phosphorus) in air or oxygen. The $\mathrm{O} / \mathrm{Pu}$ ratio of the product is, however, normally greater than $2[24,25]$, being as much as 2.09 for the oxide obtained from $\mathrm{Pu}\left(\mathrm{SO}_{4}\right)_{2}$ in air. Since ignition to $\mathrm{PuO}_{2}$ is often used as a method of analysis for the lower oxides, this is an important effect. As most of the work on this phenomenon was carried out before the lower oxides were well characterized, there have been no detailed studies of the composition of the product from the lower oxides specifically. However, oxidation of the metal in air which probably goes through the lower oxides gives $\mathrm{O} / \mathrm{Pu}$ ratios varying from 2.00 to 2.03 [24, 25]. Gardner et al. [13] claim that lower oxide pellets do not absorb oxygen above a composition of $\mathrm{PuO}_{2}$ when heated in air. Jackson and Rand [26] have shown that this excess oxygen in plutonium dioxide is due entirely to surface adsorption rather than to bulk oxidation as in $\mathrm{UO}_{2}$. They also found that the amount of oxygen adsorbed from air was up to a factor of two greater than that adsorbed from an equivalent pressure of pure oxygen at the same temperature. The preparative routes for $\mathrm{PuO}_{2}$ are summarized in Table $\mathrm{I}$. 
o TABLE I: SUMMARY OF METHODS FOR THE PREPARATION OF PUO 2 : INTERMEDIATF PRECIPITATION ANI CONVERSION DE'TAILS

\begin{tabular}{|c|c|c|c|c|c|c|c|c|c|c|c|c|}
\hline Intermediate & Process & $\begin{array}{c}\text { Scale } \\
\mathrm{Pu}(\mathrm{g} / \text { litre })\end{array}$ & $\begin{array}{l}\text { Strike } \\
\text { solution }\end{array}$ & $\begin{array}{l}\text { Precipitation } \\
\text { temperature } \\
\text { ("C) }\end{array}$ & $\begin{array}{l}\text { Digestion } \\
\text { temperature } \\
\text { ("C) }\end{array}$ & $\begin{array}{l}\text { Digestion } \\
\text { tine } \\
\text { (h) }\end{array}$ & $\begin{array}{c}\text { Filtration } \\
\text { characteristics }\end{array}$ & $\begin{array}{l}\text { Drying } \\
\text { tempera ture } \\
\text { ("C) }\end{array}$ & $\begin{array}{l}\text { Drying } \\
\text { time } \\
\text { (h) }\end{array}$ & $\begin{array}{l}\text { Calcination } \\
\text { temperature } \\
\text { ("C) }\end{array}$ & $\begin{array}{l}\text { Calcination } \\
\text { time } \\
\text { (h) }\end{array}$ & References \\
\hline Pu metal & $\begin{array}{l}\text { Air } \\
\text { oxidation }\end{array}$ & - & - & $160-670^{a}$ & - & $1-4^{a}$ & - & - & - & - & - & {$[27-30]$} \\
\hline Dy nitrate & Denitration & - & - & - & - & - & - & 300 & :t & $300-1000$ & $: 9-22$ & {$[4,31,32]$} \\
\hline $\mathrm{Pu}$ & Ammonium & $1 \cdot: n 0$ & $\mathrm{NH}_{4} \mathrm{OH}$ & $25-30$ & 100 & $0.16-72$ & Poor & 110 & 26 & $250-750$ & 0.75 & \\
\hline \multirow[t]{3}{*}{ hydroxide } & hydroxide & & $\mathrm{NH}_{4} \mathrm{OH}$ & $55-95$ & $55-45$ & 0.5 & Good & 110 & 26 & $250-7501$ & 0.75 & {$[33-39]$} \\
\hline & precipitation & & $\mathrm{NH}_{3} \mathrm{gas}^{3 \mathrm{~s}}$ & 55 & 55 & 0.5 & Poor & 100 & 26 & 8.40 & 1.3 & \\
\hline & & & Urea & $95-100$ & $95-100$ & $2-22$ & Good & 100 & $: 46$ & $254-8.50$ & 2.0 & \\
\hline $\mathrm{Pu}_{2}\left(\mathrm{C}_{2} \mathrm{O}_{4}\right)_{3}$ & $\begin{array}{l}\text { Oxalate } \\
\text { precipitation }\end{array}$ & $1-100$ & $\mathrm{H}_{2} \mathrm{C}_{2} \mathrm{O}_{4}$ & $25-30$ & $25-30$ & 0.5 & Good & - & - & 950 & 1.0 & {$[33,35,38$} \\
\hline $\operatorname{Pu}\left(\mathrm{C}_{2} \mathrm{O}_{4}\right)_{2}$ & $\begin{array}{l}\text { Oxalate } \\
\text { precipitation }\end{array}$ & $1-250$ & $\begin{array}{l}\mathrm{H}_{2} \mathrm{C}_{2} \mathrm{O}_{4} \\
+\mathrm{H}_{2} \mathrm{O}_{2}\end{array}$ & $35-55$ & $35-55$ & 0.5 & Good & $100-180$ & $1-24$ & $350 \cdot 760$ & 0.5 & $70-8,3$ \\
\hline $\begin{array}{l}\text { Pu } \\
\text { peroxide }\end{array}$ & $\begin{array}{l}\text { Peroxide } \\
\text { precipitation }\end{array}$ & $10-100$ & $\mathrm{H}_{2} \mathrm{O}_{2}$ & $15-20$ & $5-15$ & $0.5-2.5$ & Good & 55 & 48 & $250-760$ & 0.5 & {$[50-53]$} \\
\hline $\begin{array}{l}\mathrm{PuCl}_{3} \text { in } \\
\text { alkali } \\
\text { chloride melt }\end{array}$ & $\begin{array}{l}\text { High } \\
\text { temperature } \\
\text { precipitation }\end{array}$ & - & $\begin{array}{l}\mathrm{O}_{2}-\mathrm{Cl}_{2} \\
\text { gas }\end{array}$ & $400-600$ & - & - & Good & - & - & - & - & {$[5,4]$} \\
\hline
\end{tabular}

${ }^{a}$ Reaction temperature and time. 
The preparative route and process details have a significant influence on the product $\mathrm{PuO}_{2}$ characteristics, which affect subsequent fabrication and sintering properties of fuel materials containing $\mathrm{PuO}_{2}$. From the process point of view, precipitation of $\mathrm{Pu}(\mathrm{IV})$ oxalate appears particularly attractive. Plutonium losses in the filtrate are nominal, filtration characteristics of $\mathrm{Pu}\left(\mathrm{C}_{2} \mathrm{O}_{4}\right)_{2} \cdot 6 \mathrm{H}_{2} \mathrm{O}$ are excellent, and reproducibility of the product $\mathrm{PuO}_{2}$ powder characteristics is good. The $\mathrm{PuO}_{2}$ from this route has comparatively low bulk and tap density, its surface area may be controlled by varying the calcination temperature, and a narrow particle size distribution is obtained. The material has good pressing and sintering characteristics, final sintered densities as high as $96 \%$ theoretical being attainable. $\mathrm{PuO}_{2}$ powder obtained through $\mathrm{Pu}(\mathrm{IV})$ oxalate is also suitable for mechanical blending with $\mathrm{UO}_{2}$ and further fabrication.

Precipitation of plutonium peroxide is also a convenient route for the preparation of $\mathrm{PuO}_{2}$. However, solubility "losses" are high and the process involves handling large volumes of slurry solutions. The powder characteristics of this $\mathrm{PuO}_{2}$ are, in general, similar to those of $\mathrm{PuO}_{2}$ derived from $\mathrm{Pu}(\mathrm{IV})$ oxalate except that the tap densities are higher from the peroxide.

Ammoniacal precipitation does not appear attractive from a process point of view. Solubility "Iosses" are low, but the filtration characteristics of the precipitate are particularly bad for precipitations at room temperature, although high-temperature precipitation $\left(95\right.$ to $\left.100^{\circ} \mathrm{C}\right)$ with ammonium hydroxide or urea facilitates quicker filtration. The $\mathrm{PuO}_{2}$ characteristics do not correlate well with the precipitation and conversion details. The powder calcined at temperatures over $750^{\circ} \mathrm{C}$ has a high tap density (about $5 \mathrm{~g} / \mathrm{cm}^{3}$ ) and is suited for further fabrication by vibration-compaction and sintering (sintered densities vary from 83.5 to $93.5 \%$ of the theoretical density).

$\mathrm{PuO}_{2}$ may be prepared in highly crystalline [54] form from molten alkali chloride solutions by sparging with an $\mathrm{O}_{2}-\mathrm{Cl}_{2}$ gas stream. The bulk density of the material is approximately $6 \mathrm{~g} / \mathrm{cm}^{3}$ and this might find use as an excellent intermediate for fabrication by vibration-compaction and sintering.

\subsection{Higher oxides of plutonium}

Brewer [55], has predicted from thermodynamic considerations that any solid anhydrous oxide of plutonium higher than $\mathrm{PuO}_{2}$ will probably not be stable. In this respect plutonium resembles thorium rather than its immediate analogues, neptunium and uranium.

Attempts were made to prepare a higher oxide by the controlled ignition of plutonyl nitrate, $\mathrm{PuO}_{2}\left(\mathrm{NO}_{3}\right)_{2} \cdot \mathrm{xH}_{2} \mathrm{O}$, but the nitrate decomposed to the dioxide at $275^{\circ} \mathrm{C}$ [4]. Heating $\mathrm{PuO}_{2}$ in oxygen at $400^{\circ} \mathrm{C}$ and under $70 \mathrm{~atm}$ pressure, in ozone at 600 to $1000^{\circ} \mathrm{C}$, and in atomic oxygen failed to produce a higher oxide [4]. Katz and Gruen [56] have reported that $\mathrm{PuO}_{2}$ was not oxidized by nitrogen dioxide at $500^{\circ} \mathrm{C}$. Bagnall and Laidler [57], however, have reported the isolation of a plutonium trioxide hydrate by the action of ozonized oxygen on $\mathrm{Pu}(\mathrm{IV})$ hydroxide at $90^{\circ} \mathrm{C}$. The reddish- 
gold material formed by vacuum drying at $130^{\circ} \mathrm{C}$ had the composition $\mathrm{PuO}_{3} \cdot 0.8 \mathrm{H}_{2} \mathrm{O}$, but its $\mathrm{X}$-ray pattern showed that it was not isostructural with any known uranium trioxide hydrate. Nevertheless, it is probably best to regard it as plutonyl hydroxide.

\section{PHASE DIAGRAM}

\subsection{Crystal structures}

\subsubsection{Established structures}

2.1.1.1. Hexagonal $\mathrm{Pu}_{2} \mathrm{O}_{3}$. This phase is the lowest oxide in the system and is stable in contact with $\mathrm{Pu}$ metal. The structure is hexagonal, $\mathrm{La}_{2} \mathrm{O}_{3}$ type, with $\mathrm{a}=3.841 \pm 0.006$ and $\mathrm{c}=5.958 \pm 0.005 \AA$ with one formula unit per unit cell. The space group is $P \overline{3} \mathrm{~m} 1$, the calculated density is $11.47 \mathrm{~g} / \mathrm{cm}^{3}$ [58]. The structure is that of the a-form rare earth sesquioxide and is isotypic with $\mathrm{Ac}_{2} \mathrm{O}_{3}$ and hex $-\mathrm{Am}_{2} \mathrm{O}_{3}$.

$A$ variant of hexagonal $\mathrm{Pu}_{2} \mathrm{O}_{3}$ has been found by $Z$ achariasen in examining data obtained at Los Alamos. Several preparations showed some diffuse diffraction lines, indicating stacking disorder. In a unique preparation made at high temperature the diffuse lines were consistent with the existence of a stacking fault every sixth $c$-period giving rise to an ordered superstructure with hexagonal axis, $a=3.842 \pm 0.001$ and $c=108.41 \pm 0.01 \AA(=18 \times 6.023 \AA)$.

2.1.1.2. Cubic $\mathrm{PuO}_{1,52}$. This structure is body-centred cubic, bixbyite type with $a=11.047-11.07 \AA$. There are 32 metal atoms and 48 oxygen atoms per unit cell (for the ideal composition $\mathrm{PuO}_{1.5}$ ). The space group is Ia 3 , the calculated density is $10.2 \mathrm{~g} / \mathrm{cm}^{3}$. The structure of this phase, which appears to exist only below $300^{\circ} \mathrm{C}$, is well established from X-ray powder diffraction data as that of the $c$-form rare-earth sesquioxides and is isotypic with cubic $\mathrm{Am}_{2} \mathrm{O}_{3}$ and $\mathrm{Cm}_{2} \mathrm{O}_{3}$. Workers at Harwell [13] have suggested that its composition is $\mathrm{PuO}_{1.52}$. Whether or not this phase is a low-temperature modification of hexagonal $\mathrm{Pu}_{2} \mathrm{O}_{3}$ is at present an open question. The similarity of this structure with those of $\mathrm{PuO}_{1.61}$ and $\mathrm{PuO}_{2}$ is discussed below.

2.1.1.3. Cubic $\mathrm{PuO}_{1,61+y}$. The true structure of this phase, which is stable only above $350^{\circ} \mathrm{C}$, has not been established; above $650^{\circ} \mathrm{C}$ it may merely be the lower limit of the substoichiometric plutonia phase. The structure is, however, closely related to that of cubic $\mathrm{PuO}_{1.52}$ and hence may be tentatively described as cubic with $\mathrm{a}=11.03 \AA$ at $350^{\circ} \mathrm{C}$; there are 32 metal atoms and an assumed 51 or 52 oxygen atoms per unit cell for the $\mathrm{PuO}_{1.61}$ composition. In $\mathrm{X}$-ray films taken at temperatures above $300^{\circ} \mathrm{C}$, only the strong pseudo face-centred cubic reflections have been seen. In films of quenched samples at room temperature taken at Los Alamos the weak body-centred cubic reflections are also seen, suggesting that the structure may be body-centred cubic above $300^{\circ} \mathrm{C}$. At room temperature the $\mathrm{X}$-ray powder pattern of $\mathrm{PuO}_{1.61}$ is distinguished 
from that of $\mathrm{PuO}_{1.52}$ by the smaller lattice parameter and also by the relative intensities of the reflections for which $\mathrm{h}^{2}+\mathrm{k}^{2}+1^{2}=190$ and 192 . For $\mathrm{PuO}_{1.52,} \mathrm{I}_{190}: \mathrm{I}_{192}=10: 3$ and for $\mathrm{PuO}_{1.6}, \mathrm{I}_{190}: \mathrm{I}_{192}=7: 10$. The shift in intensity is a consequence of a change in the $\mathrm{Pu}$ atom position parameter, $\mathrm{x}$, from -0.030 for the bixbyite structure to -0.020 for $\mathrm{PuO}_{1.61}$ (see Section II. 2.1.3).

2.1.1.4. Plutonium dioxide. This is the highest oxide in the system. The structure [2], which is isotypic with dioxides of some of the rareearth, and all other actinide elements up to at least curium, is facecentred cubic, fluorite-type, with $a=5.3960 \pm 0.0003 \AA$, space group Fm $3 \mathrm{~m}$. With four formula units per unit cell, the cálculated density is $11.46 \mathrm{~g} \mathrm{~cm}^{-3}$. However, in common with all $\alpha$-active materials, the lattice parameter increases with time $[59,60]$ owing to the introduction of Frenkel defects into the lattice as a result of the $\alpha$-decay process. The precise rate of increase depends on the isotopic composition, but for plutonium containing $\sim 95 \% \quad{ }^{239} \mathrm{Pu}$ and $\sim 5 \% \quad{ }^{240} \mathrm{Pu}$, the parameter is given by

$$
\mathrm{a}(\AA)=5.3960+0.0182\left(1-\exp \left(-9.64 \times 10^{-4} \mathrm{t}\right)\right)
$$

where $t$ is the time in days that has elapsed since the oxide was prepared or last annealed. The self-damage anneals out fairly uniformly as the temperature is heated to $1000^{\circ} \mathrm{C}[60]$.

At temperatures above about $650^{\circ} \mathrm{C}, \mathrm{PuO}_{2}$ can exist with a considerable oxygen deficiency, down to at least $\mathrm{PuO}_{1.7}$ and perhaps as far as $\mathrm{PuO}_{1.61}$. The effect of removing oxygen is to expand the lattice, and Atlas et al. [61]. have shown from density measurements at $750^{\circ} \mathrm{C}$ that this involves oxygen vacancies rather than interstitial plutonium ions. Although pure $\mathrm{PuO}_{2-x}$ can apparently not be quenched to room temperature, it has been observed at Los Alamos that tantalum or tungsten impurity will stabilize $\mathrm{PuO}_{2-\mathrm{x}}$ with an enlarged lattice parameter at $25^{\circ} \mathrm{C}[62]$.

\subsubsection{X-ray powder patterns of the plutonium oxides}

The computed powder diffraction patterns of $\mathrm{PuO}_{2}$, cubic $\mathrm{PuO}_{1.52}$ and hexagonal $\mathrm{Pu}_{2} \mathrm{O}_{3}$ are given in Tables II-IV. The computed intensities include contributions from the oxygen atoms as well as the plutonium atoms. For hexagonal $\mathrm{Pu}_{2} \mathrm{O}_{3}$ (Table II) the atomic positions are $2 \mathrm{Pu}$ in (d), with $z=0.235$, and $1 \mathrm{O}$ in (a) and $2 \mathrm{O}$ in (d), with $\mathrm{z}=0.63$. The values for $\mathrm{z}$ are those for $\mathrm{La}_{2} \mathrm{O}_{3}$.

The atomic positions and parameters for the other three cubic oxides are given in Table $\mathrm{V}$. The positions of the oxygen atoms in $\mathrm{PuO}_{1.52}$ and $\mathrm{PuO}_{1.61}$ are assumed to be the same as those in bixbyite.

The patterns for cubic $\mathrm{PuO}_{1.52}$ and $\mathrm{PuO}_{1.6}$ are quite similar to the pattern for $\mathrm{PuO}_{2}$, as the strong reflections are those of the face-centred cubic metal lattice. The additional reflections that occur because of the body-centred cubic symmetry and larger unit cell are weak, although 
TABLE II. POWDER PATTERN FOR HEXAGONAL $\mathrm{Pu}_{2} \mathrm{O}_{3}$ $\mathrm{a}_{0}=3.840 \AA \quad$ Copper radiation $\lambda\left(\mathrm{K} \alpha_{1}\right)=1.54051 \AA$ $\mathrm{c}_{0}=5.957 \AA$

\begin{tabular}{|c|c|c|c|c|c|c|}
\hline $2 \theta$ & $\sin ^{2} \theta$ & d-spacing & Intensity & $\mathrm{h}$ & $\mathrm{k}$ & 1 \\
\hline 26.81 & 0537 & 3.326 & 27 & 0 & 1 & 0 \\
\hline 30.00 & 0670 & 2.979 & 24 & 0 & 0 & 2 \\
\hline 30.79 & 0705 & 2.904 & 100 & 0 & 1 & 1 \\
\hline 40.66 & 1207 & 2.219 & 23 & 0 & 1 & 2 \\
\hline 47.35 & 1612 & 1.920 & 26 & 1 & 1 & 0 \\
\hline 53.77 & 2045 & 1.705 & 22 & 0 & 1 & 3 \\
\hline 55.24 & 2149 & 1.663 & 3 & 0 & 2 & 0 \\
\hline 57.07 & 2282 & 1.614 & 22 & 1 & 1 & 2 \\
\hline 57.55 & 2317 & 1.602 & 16 & 0 & 2 & 1 \\
\hline 62.35 & 2680 & 1.489 & 3 & 0 & 0 & 4 \\
\hline 64.14 & 2819 & 1.452 & 5 & 0 & 2 & 2 \\
\hline 69.11 & 3217 & 1.359 & 4 & 0 & 1 & 4 \\
\hline 74.42 & 3657 & 1.275 & 8 & 0 & 2 & 3 \\
\hline 75.66 & 3762 & 1.257 & 3 & 1 & 2 & 0 \\
\hline 77.63 & 3929 & 1.230 & 12 & 1 & 2 & 1 \\
\hline 81.86 & 4292 & 1.177 & 6 & 1 & 1 & 4 \\
\hline 83.47 & 4431 & 1.158 & 4 & 1 & 2 & 2 \\
\hline 86.84 & 4724 & 1.122 & 4 & 0 & 1 & 5 \\
\hline 88.12 & 4836 & 1.109 & 4 & 0 & 3 & 0 \\
\hline 93.08 & 5269 & 1.052 & 8 & 1 & 2 & 3 \\
\hline 95.81 & 5506 & 1.039 & 5 & 0 & 3 & 2 \\
\hline 105.50 & 6336 & 0.969 & 3 & 0 & 2 & 5 \\
\hline
\end{tabular}


TABLE II. (cont.)

\begin{tabular}{|c|c|c|c|c|c|c|}
\hline $2 \theta$ & $\sin ^{2} \theta$ & d-spacing & Intensity & $\mathrm{h}$ & k & 1 \\
\hline 106.75 & 6441 & 0.961 & 3 & 1 & 2 & 4 \\
\hline 106.84 & 6448 & 0.960 & 3 & 2 & 2 & 0 \\
\hline 115.07 & 7118 & 0.914 & 4 & 2 & 2 & 2 \\
\hline 115.51 & 7153 & 0.912 & 7 & 1 & 3 & 1 \\
\hline 120.21 & 7516 & 0.889 & 4 & 0 & 3 & 4 \\
\hline 121.88 & 7641 & 0.882 & 3 & 1 & 1 & 6 \\
\hline 122.08 & 7656 & 0.881 & 3 & 1 & 3 & 2 \\
\hline 126.13 & 7948 & 0.865 & 7 & 1 & 2 & 5 \\
\hline 134.32 & 8493 & 0.837 & 8 & 1 & 3 & 3 \\
\hline 138.48 & 8743 & 0.824 & 3 & 0 & 1 & 7 \\
\hline 138.86 & 8765 & 0.823 & 4 & 0 & 4 & 1 \\
\hline 145.65 & 9128 & 0.807 & 6 & 2 & 2 & 4 \\
\hline 148.60 & 9268 & 0.801 & 3 & 0 . & 4 & 2 \\
\hline 158.92 & 9665 & 0.784 & 6 & 1 & 3 & 4 \\
\hline 163.36 & 9791 & 0.779 & 10 & 1 & 2 & 6 \\
\hline 164.50 & 9818 & 0.778 & 6 & 1 & 1 & 7 \\
\hline
\end{tabular}

many are visible in films of well-crystallized material. As noted above, the extra body-centred cubic reflections for $\mathrm{PuO}_{1.61}$ have not been observed in the poor quality films obtained at high temperatures.

\subsubsection{Comparison of the structures}

To provide a clear view of the similarity in structure, Table $\mathrm{V}$ describes the detailed structures of the three cubic oxides as based on space group Ia 3. This requires doubling of the correct unit cell dimension for $\mathrm{PuO}_{2}$. In $\mathrm{PuO}_{1.61}$ there must be either three or four extra oxygen atoms in the cell, giving ideal formulae of $\mathrm{PuO}_{1.594}$ or $\mathrm{PuO}_{1.625}$. The latter is more probable, since this allows eight $\mathrm{Pu}(\mathrm{IV})$ atoms to occupy the 8 -fold b-positions, and $24 \mathrm{Pu}$ (III) atoms to occupy the 24-fold d- 
TABLE III. POWDER PATTERN FOR CUBIC PuO 1.52 (reflections with an intensity of 2 or less have been omitted)

$a_{0}=11.050 \AA$ Copper radiation $\lambda\left(K \alpha_{1}\right)=1.54051 \AA$

Body-centred cubic

\begin{tabular}{|c|c|c|c|c|c|c|c|c|c|c|}
\hline $2 \theta$ & $\sin ^{2} \theta$ & d-spacing & Intensity & $\mathrm{h}$ & $\mathrm{k}$ & 1 & & & & \\
\hline 19.66 & 0292 & 4. 511 & 5 & 1 & 1 & 2 & & & & \\
\hline 27.95 & 0583 & 3.190 & 71 & 2 & 2 & 2 & & & & \\
\hline 32.38 & 0777 & 2.763 & 32 & 0 & 0 & 4 & & & & \\
\hline 34.40 & 0875 & 2.605 & 5 & 1 & 1 & 4 & & & & \\
\hline 38.17 & 1069 & 2.356 & 5 & 2 & 3 & 3 & & & & \\
\hline 41.64 & 1263 & 2.167 & 8 & 1 & 3 & 4 & & & & \\
\hline 46.45 & 1555 & 1.953 & 51 & 0 & 4 & 4 & & & & \\
\hline 47.96 & 1652 & 1.895 & 3 & 3 & 3 & 4 & & & & \\
\hline 50.90 & 1846 & 1.793 & 6 & 1 & 1 & 6,2 & 3 & 5 & & \\
\hline 53.71 & 2041 & 1.705 & 6 & 1 & 4 & 5 & & & & \\
\hline 55.08 & 2138 & 1.666 & 55 & 2 & 2 & 6 & & & & \\
\hline 36.43 & 2235 & 1.629 & 9 & 1 & 3 & 6 & & & & \\
\hline 57.76 & 2332 & 1.595 & 13 & 4 & 4 & 4 & & & & \\
\hline 59.06 & 2429 & 1.563 & 4 & 3 & 4 & 5 & & & & \\
\hline 61.63 & 2624 & 1.504 & 5 & 1 & 2 & 7,3 & 3 & 6,2 & 5 & 5 \\
\hline 62.88 & 2721 & 1.477 & 3 & 2 & 4 & 6 & & & & \\
\hline 66.58 & 3013 & 1.403 & 6 & 1 & 5 & 6,2 & 3 & 7 & $\cdot$ & \\
\hline 67.79 & 3110 & 1.381 & 10 & 0 & 0 & 8 & & & & \\
\hline 68.98 & 3207 & 1.360 & 10 & 1 & 1 & 8,4 & 5 & 5,1 & 14 & 7 \\
\hline 70.17 & 3304 & 1.340 & 4 & 4 & 4 & 6,0 & 2 & 8 & & \\
\hline 71.35 & 3401 & 1.321 & 5 & 3 & 5 & 6 & & & & \\
\hline 72.52 & 3498 & 1.302 & 3 & 0 & 6 & 6,2 & 2 & 8 & & \\
\hline
\end{tabular}


TABIEE III. (cont.)

\begin{tabular}{|c|c|c|c|c|c|c|c|c|c|c|}
\hline $2 \theta$ & $\sin ^{2} \theta$ & d-spacing & Intensity & $\mathrm{h}$ & $\mathrm{k}$ & 1 & & & & \\
\hline 73.69 & 3596 & 1.285 & 9 & 1 & 3 & 8,3 & 4 & 7 & & \\
\hline 74.84 & 3693 & 1.268 & 23 & 2 & 6 & 6 & & & & \\
\hline 77.14 & 3887 & 1.235 & 19 & 0 & 4 & 8 & & & & \\
\hline 78.28 & 3984 & 1.220 & 3 & 3 & 3 & 8 & & & & \\
\hline 79.42 & 4082 & 1.206 & 3 & 2 & 4 & 8 & & & & \\
\hline 80.55 & 4179 & 1.192 & 7 & 1 & 2 & 9,1 & 6 & 7,5 & 5 & 6 \\
\hline 82.80 & 4373 & 1.165 & 6 & 1 & 5 & 8.4 & 5 & 7 & & \\
\hline 85.04 & 4567 & 1.140 & 6 & 3 & 6 & 7,2 & 3 & 9 & & \\
\hline 86.15 & 4665 & 1.128 & 18 & 4 & 4 & 8 & & & & \\
\hline 87.27 & 4762 & 1.116 & 7 & 1 & 4 & 9,3 & 5 & 8 & & \\
\hline 88.38 & 4859 & 1.105 & 4 & 0 & 6 & 8,0 & 0 & 10 & & \\
\hline 89.50 & 4956 & 1.094 & 3 & 1 & 1 & 10,2 & 7 & 7 & & \\
\hline 90.61 & 5053 & 1.084 & 9 & 2 & 6 & 8,0 & 2 & 10 & & \\
\hline 92.84 & 5248 & 1.063 & 19 & 6 & 6 & 6.2 & 21 & 10 & & \\
\hline 93.96 & 5345 & 1.054 & 9 & 2 & 5 & 9,5 & 6 & 7,1 & 3 & 10 \\
\hline 96.19 & 5539 & 1.035 & 8 & 1 & 7 & 8,5 & 5 & 8,4 & 7 & 7 \\
\hline 97.31 & 5636 & 1.026 & 8 & 0 & 4 & 10,4 & 6 & 8 & & \\
\hline 98.44 & 5734 & 1.017 & 6 & 1 & 6 & 9,3 & 3 & 10 & & \\
\hline 99.56 & 5831 & 1.009 & 7 & 2 & 4 & 10 & & & & \\
\hline 100.70 & 5928 & 1.000 & 6 & 4 & 5 & 9,3 & 7 & 8 & & \\
\hline 102.97 & 6122 & 0.984 & 9 & 3 & 6 & 9,1 & 5 & 10,1 & 2 & 11 \\
\hline 104.12 & 6219 & 0.977 & 6 & 0 & 8 & 8 & & & & \\
\hline 106.43 & 6414 & 0.962 & 4 & 2 & 8 & 8,4 & 4 & 10 & & \\
\hline 107.59 & 6511 & 0.955 & 9 & $\begin{array}{l}6 \\
2\end{array}$ & $\begin{array}{l}7 \\
3\end{array}$ & $\begin{array}{ll}7,2 & 2 \\
11 & \end{array}$ & 7 & 9,3 & 5 & 10, \\
\hline 108.76 & 6608 & 0.948 & 3 & 0 & 6 & 10,6 & 6 & 8 & & \\
\hline
\end{tabular}


TABLE III. (cont.)

\begin{tabular}{|c|c|c|c|c|c|c|c|c|c|c|}
\hline $2 \theta$ & $\sin ^{2} \theta$ & $d$-spacing & Intensity & h & $\mathrm{k}$ & 1 & & & & \\
\hline 109.94 & 6705 & 0.941 & 7 & 1 & 4 & 11,5 & 7 & 8 & & \\
\hline 111.13 & 6803 & 0.934 & 20 & 2 & 6 & 10 & & & & \\
\hline 112.33 & 6900 & 0.927 & 4 & 5 & 6 & 9 & & & & \\
\hline 113.54 & 6997 & 0.921 & 10 & 0 & 0 & 12,4 & 8 & 8 & & \\
\hline 114.76 & 7094 & 0.915 & 11 & $\left\{\begin{array}{l}1 \\
1\end{array}\right.$ & $\begin{array}{l}1 \\
8\end{array}$ & $\begin{array}{l}12,4 \\
9\end{array}$ & 9 & 7,3 & 4 & 11. \\
\hline 115.99 & 7191 & 0.908 & 7 & 0 & 2 & 12 & & & & \\
\hline 117.24 & 7288 & 0.902 & 8 & 2 & 5 & 11,5 & 5 & 10,1 & 7 & 10 \\
\hline 118.50 & 7386 & 0.896 & 10 & 4 & 6 & 10,2 & 2 & 12 & & \\
\hline 119.77 & 7483 & 0.890 & 8 & 1 & 3 & 12,3 & 8 & 9 & & \\
\hline 122.37 & 7677 & 0.879 & 10 & 3 & 7 & 10,1 & 6 & 11 & & \\
\hline 123.70 & 7774 & 0.874 & 15 & 0 & 4 & 12 & & & & \\
\hline 125.05 & 7872 & 0.868 & 6 & 3 & 3 & 12,4 & 5 & 11,7 & 7 & 8 \\
\hline 126.42 & 7969 & 0.863 & 20 & 2 & 4 & 12,6 & 8 & 8,0 & 8 & 10 \\
\hline 127.82 & 8066 & 0.858 & 7 & 3 & 6 & 11,6 & 7 & 9,2 & 9 & 9 \\
\hline 129.24 & 8163 & 0.853 & 16 & 2 & 8 & 10 & & & & \\
\hline 130.70 & 8260 & 0.848 & 11 & 1 & 5 & 12,5 & 8 & 9 & & \\
\hline 132.18 & 8357 & 0.843 & 9 & 6 & 6 & 10 & & & & \\
\hline 133.70 & 8455 & 0.838 & 8 & 1 & 2 & 13,2 & 7 & 11,5 & 7 & 10 \\
\hline 135.26 & 8552 & 0.833 & 11 & 4 & 4 & 12 & & & & \\
\hline 136.87 & 8649 & 0.828 & 6 & 3 & 5 & 12,4 & 9 & 9 & & \\
\hline 138.52 & 8746 & 0.824 & 30 & 0 & 6 & 12,4 & 8 & 10 & & \\
\hline 140.23 & 8843 & 0.819 & 14 & 2 & 3 & 13,1 & 9 & 10,5 & 6 & 11 \\
\hline 142.01 & .8941 & 0.815 & 26 & 2 & 6 & 12 & & & & \\
\hline 143.86 & 9038 & 0.810 & 19 & 1 & 4 & 13,1 & 8 & 11,4 & 7 & 11 \\
\hline 147.82 & 9232 & 0.802 & 10 & 3 & 9 & 10 & & & & \\
\hline
\end{tabular}


TABLE III. (cont.)

\begin{tabular}{|c|c|c|c|c|c|c|c|c|c|c|c|}
\hline $2 \theta$ & $\sin ^{2} \theta$ & d-spacing & Intensity & $\mathrm{h}$ & $\mathrm{k}$ & 1 & & & & & \\
\hline 149.98 & 9329 & 0.798 & 3 & 8 & 8 & 8 & & & & & \\
\hline 152.29 & 3426 & 0.793 & 43 & $\left\{\begin{array}{l}3 \\
3\end{array}\right.$ & $\begin{array}{l}4 \\
8\end{array}$ & $\begin{array}{l}13,1 \\
11\end{array}$ & 7 & 12. & 7 & 8 & 9. \\
\hline 154.79 & 9524 & 0.789 & 38 & 4 & 6 & 12,0 & 0 & 14 & & & \\
\hline 157.54 & 9621 & 0.785 & 20 & $\left\{\begin{array}{l}2 \\
1\end{array}\right.$ & $\begin{array}{l}5 \\
1\end{array}$ & $\begin{array}{l}13,6 \\
14,7\end{array}$ & $\begin{array}{l}9 \\
7\end{array}$ & $\begin{array}{l}9, \\
10\end{array}$ & & & \\
\hline 160.66 & 9718 & 0.781 & 60 & 0 & 2 & 14,6 & 8 & 10. & 0 & 10 & 10 \\
\hline 164.37 & 9815 & 0.778 & 14 & 3 & 7 & 12 & & & & & \\
\hline 169.25 & 9912 & 0.774 & 100 & 2 & 10 & 10,2 & 2 & 14 & & & \\
\hline
\end{tabular}

positions. However, since there are no 4 -fold positions in this space group, the four additional oxygen atoms are presumably randomly distributed among the 16 vacant c-positions: i.e. $\mathrm{PuO}_{1.625}$ (or $\mathrm{PuO}_{1.61}$ ) contains some oxygen disorder.

The discussion, of course, refers to the quenched room temperature structure of $\mathrm{PuO}_{1.61}$, which is body-centred cubic. It is not yet known whether the high-temperature structure is body-or face-centred cubic (see below). If it is the latter, the plutonium atoms are all on facecentred cubic positions (i.e. the $24 \mathrm{Pu}$ atoms in d-positions have $\mathrm{x}=0$ ) and the 52 (or 51 ) oxygen atoms are randomly distributed among the $64(\mathrm{c}+\mathrm{e})$ positions.

It is a further possibility that the poor quality of the diffraction patterns of $\mathrm{PuO}_{1.61}$ at high temperatures implies that the structure is slightly distorted from true cubic symmetry.

Because the three structures are all so similar, it appears plausible at first sight that a continuous transition could be achieved from the facecentred cubic $\mathrm{PuO}_{2}$ to the cubic $\mathrm{PuO}_{1.61}$. One can start with $\mathrm{PuO}_{2}$, produce $\mathrm{PuO}_{2-\mathrm{x}}$ by a random removal of oxygen to create anion vacancies in random positions until a composition of $\mathrm{PuO}_{1.61}$ is reached. Now if $\mathrm{PuO}_{1.61}$ has a body-centred cubic structure, the oxygen atoms and hence the anion vacancies are ordered, and a continuous transition from $\mathrm{PuO}_{2}$ to $\mathrm{PuO}_{1.61}$ is not possible because at some point ordering of the vacancies must occur. The disorder-order transition would presumably produce a miscibility gap in the phase diagram.

Some evidence indicating that $\mathrm{PuO}_{1.61}$ may be body-centred cubic has been obtained at Los Alamos. X-ray films from quenched samples of $\mathrm{PuO}_{1.61}$ show clearly the "extra" body-centred cubic reflections, the lattice parameter being $11.02 \AA$ and the $I_{190}: I_{192}$ ratio that for $x=-0.020$. 
TABLE IV. POWDER PATTERN FOR PuO 2

$\mathrm{a}_{0}=5.3960 \AA$ Copper radiation $\lambda\left(\mathrm{K} \alpha_{1}\right)=1.54051 \AA$

Face-centred cubic

\begin{tabular}{|c|c|c|c|c|c|c|c|c|}
\hline $2 \theta$ & $\sin ^{2} \theta$ & d-spacing & Intensity & $\mathrm{h}$ & k & 1 & & \\
\hline 28.62 & 0611 & 3.115 & 14 & 1 & 1 & 1 & & \\
\hline 33.18 & 0815 & 2.698 & 7 & 0 & 0 & 2 & & \\
\hline 47.62 & 1630 & 1.908 & 12 & 0 & 2 & 2 & & \\
\hline 56.51 & 2241 & 1.627 & 15 & 1 & 1 & 3 & & \\
\hline 59.22 & 2445 & 1.558 & 4 & 2 & 2 & 2 & & \\
\hline 69.64 & 3260 & 1.349 & 3 & 0 & 0 & 4 & & \\
\hline 76.96 & 3872 & 1.238 & 8 & 1 & 3 & 3 & & \\
\hline 79.34 & 4075 & 1.207 & 7 & 0 & 2 & 4 & & \\
\hline 88.74 & 4891 & 1.101 & 8 & 2 & 2 & 4 & & \\
\hline 95.76 & 5502 & 1.038 & 9 & 3 & 3 & 3,1 & 1 & 5 \\
\hline 107.70 & 6520 & 0.954 & 4 & 0 & 4 & 4 & & \\
\hline 115.24 & 7132 & 0.912 & 14 & 1 & 3 & 5 & & \\
\hline 117.86 & 7336 & 0.899 & 8 & 0 & 0 & 6,2 & 4 & 4 \\
\hline 129.04 & 8150 & 0.853 & 9 & 0 & 2 & 6 & & \\
\hline 138.78 & 8761 & 0.823 & 10 & 3 & 3 & 5 & & \\
\hline 142.52 & 8966 & 0.813 & 10 & 2 & 2 & 6 & & \\
\hline 162.96 & 9780 & 0.779 & 6 & 4 & 4 & 4 & & \\
\hline
\end{tabular}

Upon heat treatment at temperatures below $300^{\circ} \mathrm{C}$, a change to the pattern for $\mathrm{PuO}_{1.52}$ is observed, and the $\mathrm{PuO}_{2-\mathrm{x}}$ pattern becomes stronger, indicating that the disproportionation

$$
\mathrm{PuO}_{1.61} \rightarrow 0.805 \mathrm{PuO}_{1.52}+0.195 \mathrm{PuO}_{1.98}
$$

has occurred. The implication is strong that the high-temperature form, $\mathrm{PuO}_{1.61}$, has been retained by the quench and that it is body-centred cubic 
TABLE V. RELATION BETWEEN OXIDE STRUCTURES BASED ON SPACE GROUP Ia 3

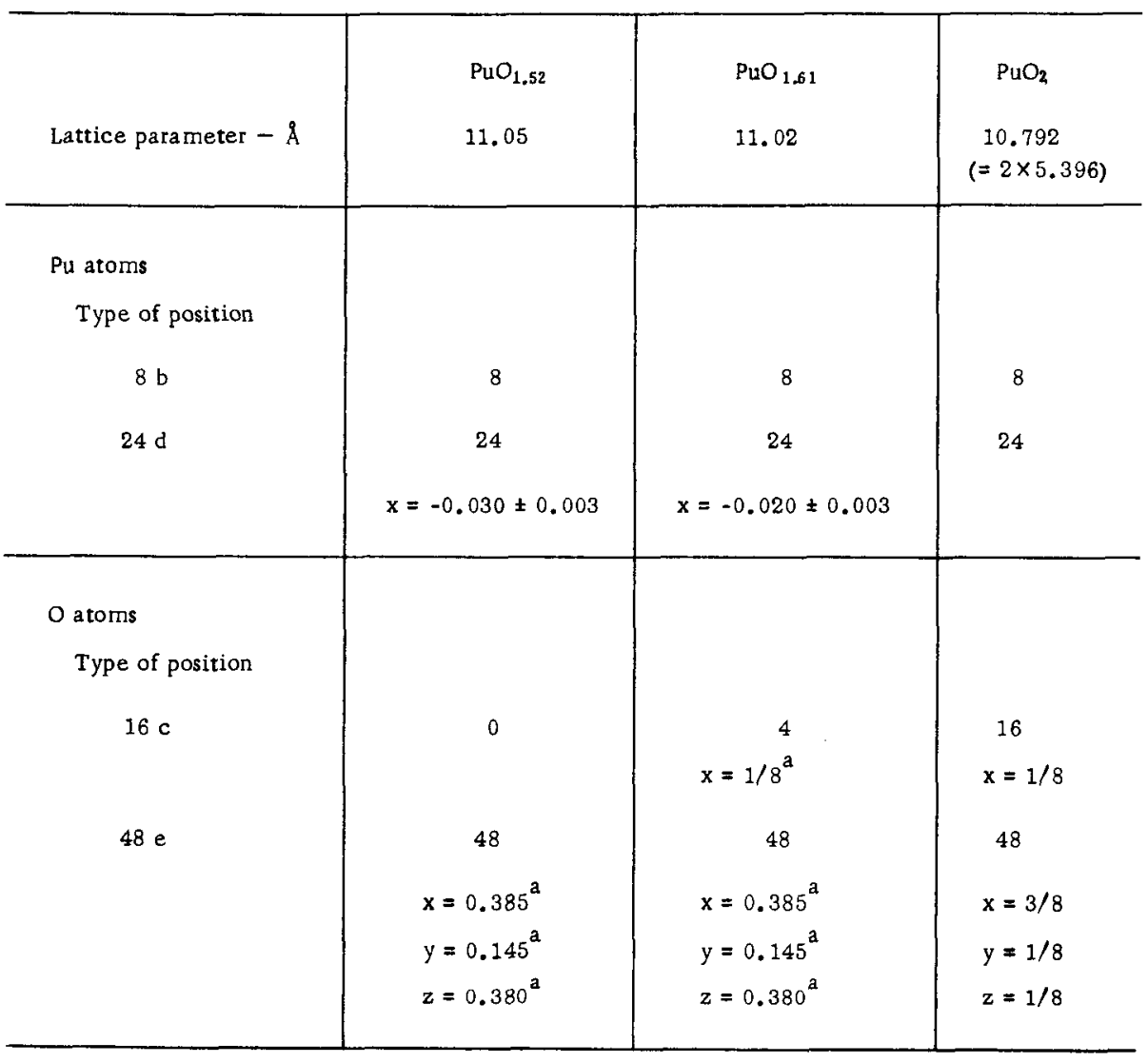

a Assumed values.

at high temperatures. The evidence is not conclusive, however, and the final decision can only be made from knowledge of the detailed structure of $\mathrm{PuO}_{1.61}$ at temperatures above $300^{\circ} \mathrm{C}$. Definite evidence showing whether or not the weak "extra" body-centred cubic lines are present in the high-temperature powder patterns of $\mathrm{PuO}_{1.61}$ is most desirable.

\subsection{Condensed phase diagram}

\subsubsection{General}

The complete phase diagram of the plutonium-oxygen system is not well established. The evidence is not as detailed as might be desired, and it is possible that future work will considerably modify any diagram chosen at this time. 


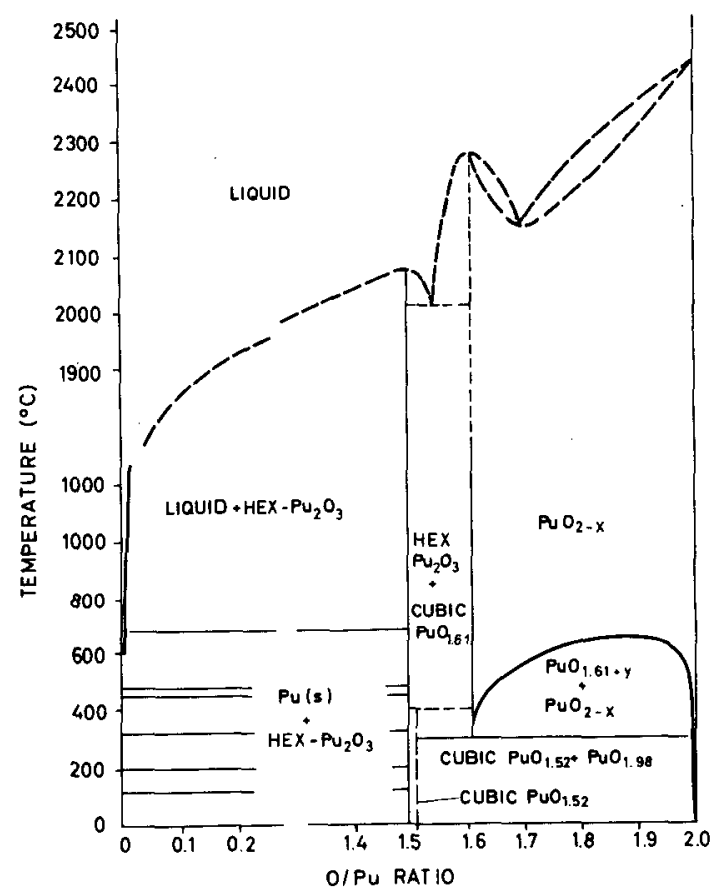

FIG.1. Tentative plutonium-oxygen phase diagram.

Three aspects may be considered separately: the phases known to exist, the melting behaviour, and the region between $\mathrm{PuO} 1.5$ and $\mathrm{PuO}_{2}$ below $1000^{\circ} \mathrm{C}$.

\subsubsection{Phases.}

The four known oxide structures, hexagonal $\mathrm{Pu}_{2} \mathrm{O}_{3}$, cubic $\mathrm{PuO}_{1.52}$, cubic $\mathrm{PuO}_{1.61}$ and $\mathrm{PuO}_{2}$ have been discussed in Section II. 2.1.1.

Plutonium monoxide, which has been shown in one proposed phase diagram [20], is now generally believed not to occur as an equilibrium phase (see Section II.1.1.), although a thin PuO film stabilized by surface energy may possibly exist. However, it is noteworthy that positive evidence that such a film is really an oxide is lacking.

\subsubsection{Melting behaviour}

The melting points of the three high-temperature phases are approximately as shown in Fig. 1 but the liquid-solid relationships sketched must be regarded as hypothetical. The problem in determining the melting behaviour of the $\mathrm{Pu}$ oxides is that the temperatures are high enough for vaporization to become a dominant factor. Both hexagonal $\mathrm{Pu}_{2} \mathrm{O}_{3}$ and $\mathrm{PuO}_{1.61}$ vaporize incongruently as does stoichiometric $\mathrm{PuO}_{2}$. The congruently vaporizing composition near the melting point is, according 
to Ackermann et al. [63], about $\mathrm{PuO}_{1.8}$. Thus, in principle, the melting point of this composition only can be observed in vacuum. The only certain statement that can be made is that the liquidus curve for the range between $\mathrm{PuO}_{1.5}$ and $\mathrm{PuO}_{2}$ lies between $2000^{\circ}$ and $2300^{\circ} \mathrm{C}$ over most of the range and rises to a maximum of about $2400^{\circ} \mathrm{C}$ or higher near stoichiometric $\mathrm{PuO}_{2}$. It is not possible to make a firm decision on details of melting behaviour from evidence at present available, nor does it appear possible to select reliable melting points from the literature.

The high temperature part of Fig. 1 follows that of Livey and Feschotte [64], which is based largely on the work of Riley [65], and is also like that suggested by Chikalla et al. [20].

\subsubsection{The $\mathrm{PuO}_{1.5}-\mathrm{PuO}_{2}$ region}

The existing situation is that there are two major pieces of experimental evidence upon which to base construction of the phase diagram in this region: the high-temperature X-ray study of Gardner et al. [13] (Fig.2), and the EMF study reported by Markin and Rand [66]. In addition some less detailed high-temperature $\mathrm{X}$-ray studies by Chikalla et al. [20], electrical resistivity measurements by McNeilly [67] and three sets of thermal expansion measurements $[20,68,69]$ give useful evidence on the position of the phase boundaries.

Several pieces of work have been derived from these primary data. Following the work of Gardner et al. [13], who constructed a phase diagram, and Markin and Rand [66], who derived free energy data from the EMF work, Rand [70] has made a thermodynamic assessment which co-ordinates all the independent but inter-related raw data. In this assessment, a phase diagram (Fig.1), very similar to but not identical with that proposed by Gardner et al. [13], was adopted as being the simplest consistent with all the known data. It is now clear, however, that the iner details of the phase diagram cannot be settled from the data at present available. For consistency, therefore, the phase diagram of Fig. 1 and the co-related thermodynamic assessment are adopted here. Other possibilities for the phase diagram are discussed in detail in the subsequent paragraphs, and it must be emphasized that at present it is impossible to endorse a single final version of the phase diagram in the $\mathrm{PuO}_{1.5}-\mathrm{PuO}_{2}$ region.

When all the evidence is considered critically, at least two possibilities for the phase diagram appear likely. One is the diagram presented in Fig. 1, showing that $\mathrm{PuO}_{1.61}$ is continuous with $\mathrm{PuO}_{2-\mathrm{x}}$ above $650^{\circ} \mathrm{C}$. This diagram implies either that $\mathrm{PuO}_{1.61}$ is face-centred cubic, or that an ordering of the oxygen sub-lattice occurs that does not give rise to any feature in the phase diagram.

A nother possibility, equally likely, is that a narrow two-phase miscibility gap exists somewhere between $\mathrm{PuO}_{1.61}$ and $\mathrm{PuO}_{2-\mathrm{x}}$ above $650^{\circ} \mathrm{C}$. This alternative diagram would be required if $\mathrm{PuO}_{1,61}$ were body-centred cubic, as is quite likely, since a continuous transition between facecentred cubic $\mathrm{PuO}_{2-\mathrm{x}}$ and body-centred cubic $\mathrm{PuO}_{1.61}$ is almost impossible to accept for structural reasons. It should be noted that detailed 


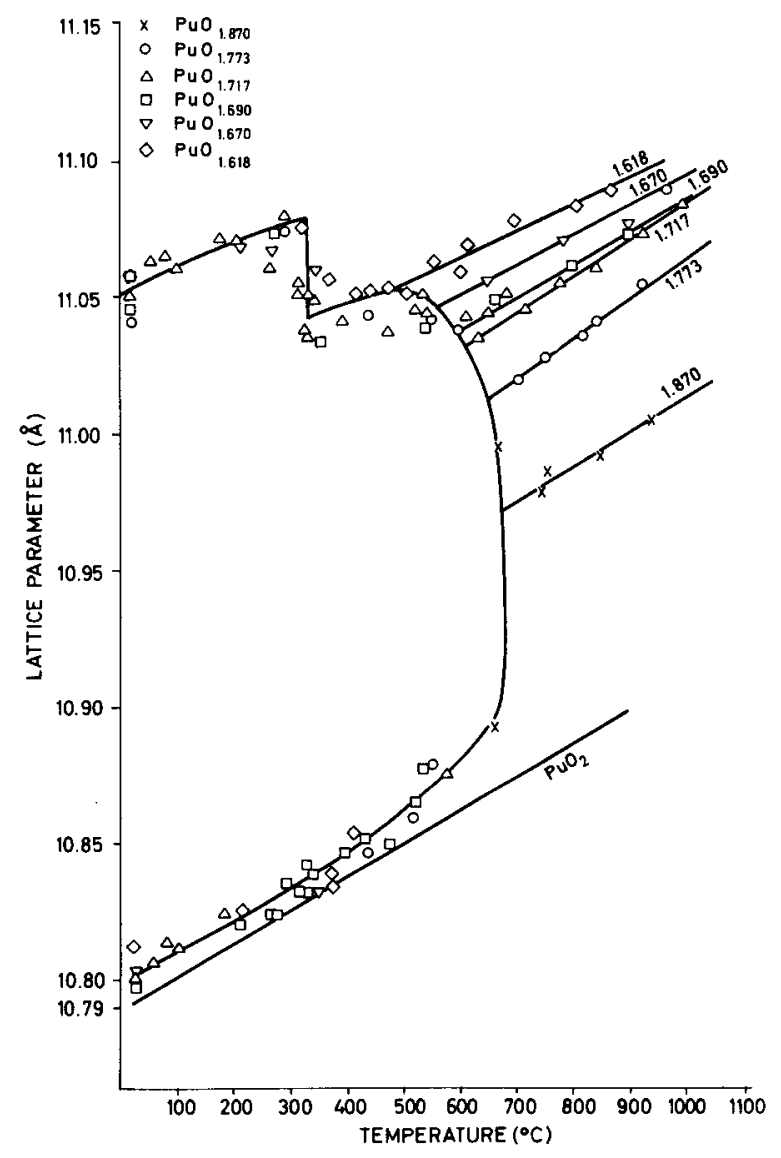

FIG.2. High-temperature lattice parameters.

work on the $\mathrm{Pr}-\mathrm{O}$ and $\mathrm{Ce}-\mathrm{O}$ systems, which exhibit wide ranges of homogeneity analogous to those in the $\mathrm{Pu}-\mathrm{O}$ system, has shown that a continuous transition from face-centred cubic $\mathrm{MO}_{2-x}$ to body-centred cubic MO1.5+y does not occur [71-74]. The two phases are separated by one or more intermediate phases (at low temperatures) or by a miscibility gap (at high temperatures). It seems fairly well established that no ordered intermediate phases exist in the $\mathrm{Pu}-\mathrm{O}$ system, but a miscibility gap appears to be quite possible.

The existence of such a diphasic region is entirely consistent with all the data mentioned above, although these do, of course, impose some restrictions on its possible position. Several possibilities remain, however, and these are discussed in Section II. 3.4, together with the changes required in the free energy diagram. To accommodate a miscibility gap no adjustment is necessary in the $X$-ray data.

In addition to the above possibilities, it is evident that the region below $300^{\circ} \mathrm{C}$ also can have alternative constructions. Evidence from which 
the horizontal at $300^{\circ} \mathrm{C}$, corresponding to the eutectoid reaction $\left\langle\mathrm{PuO}_{1.61}\right\rangle=0.805\left\langle\mathrm{PuO}_{1.52}\right\rangle+0.195\left\langle\mathrm{PuO}_{1.98}\right\rangle$, is deduced might equally well be explained by postulating that $\mathrm{PuO}_{1.52}$ and $\mathrm{PuO}_{1.61}$ are the same phase with a continuous change in oxygen content occurring over a small temperature range around $300^{\circ} \mathrm{C}$.

Evidence for the nature of the diagram around $\mathrm{PuO}_{1.5}$ is lacking. The present diagram has been drawn to obey the phase rule and to conform to the suggestion that $\left\langle\mathrm{PuO}_{1.52}\right\rangle$ contains slightly more oxygen than $\left\langle\mathrm{Pu}_{2} \mathrm{O}_{3}\right\rangle$ hex. An alternative possibility, suggested by the close resemblance of the plutonium oxide structures to those of the rare-earth oxides, is that $\left\langle\mathrm{PuO}_{1.52}\right\rangle$ is a low-temperature form of $\left\langle\mathrm{Pu}_{2} \mathrm{O}_{3}\right\rangle$ hex. Although this is attractive, it seems unlikely that experimental evidence on which to decide the point will be obtained, as the low temperature at which the transition must occur will not permit equilibrium to be achieved; even in the lanthanide oxides the expected reversion of hexagonal to cubic $\mathrm{M}_{2} \mathrm{O}_{3}$ at $\sim 800^{\circ} \mathrm{C}$ has never been observed [75].

To summarize, the phase diagram of Fig. 1 in the $\mathrm{PuO}_{1.5}-\mathrm{PuO}_{2}$ region below $1000^{\circ} \mathrm{C}$ fits all the evidence available at present, and is consistent with the thermochemical calculations of Section II. 3.4. However, alternative constructions to Fig. 1, which seem equally likely, can be postulated. Chief among these is a diagram showing a narrow miscibility gap between $\mathrm{PuO}_{1.61+y}$ and $\mathrm{PuO}_{2-\mathrm{x}}$.

Definite evidence for the structure of $\mathrm{PuO}_{1.61}$ is needed. If $\mathrm{PuO}_{1.61}$ is body-centred cubic, it is difficult to see how the diagram can be drawn without a miscibility gap. The position of such a gap will be difficult to locate exactly, since it is likely to be rather narrow. More detailed electrical resistance measurements might be helpful.

\section{THERMOCHEMICAL DATA FOR SOLID PHASES}

\subsection{Heat capacities and entropies}

3.1.1. Low-temperature heat capacities and entropies: problems with cryogenic heat capacity measurements

3.1.1.1. General. A discussion of the problems associated with radioactive materials at low temperatures is necessarily somewhat speculative as few data are available. However, the problems encountered are important as they bear directly upon the feasibility of the determination of absolute entropies for plutonium compounds from low-temperature heat capacity measurements. Two difficulties unique to radioactive species, namely self-heat and self-irradiation damage, are discussed below. We may first mention, however, that since the entropies of $\left(\mathrm{PuF}_{6}\right)$ and $(\mathrm{Pu})$ are known accurately from spectroscopic data, absolute entropies of other plutonium compounds (including the oxides) can in principle be obtained from accurate equilibrium measurements. Rand [76] has discussed this aspect of the problem. It is also true, of course, that since practical calculations deal only with entropy and free energy differences, absolute entropy values are not essential for this purpose. 
3.1.1.2. Self heat. Heat is generated in a radioactive material as a consequence of self-absorption of the radiated particles. For the plutonium most commonly available, which is principally ${ }^{239} \mathrm{Pu}$, the heat generation rate is about $7 \mathrm{cal} / \mathrm{min} \mathrm{g}-\mathrm{a}$ [77], but a complete precise calculation would need to take into account the fraction of radiation leaving the sample and heating the heat sink. Applying this value to mixtures containing other isotopes of $\mathrm{Pu}$ requires correction for the mean half life. Normally, low-temperature heat capacities are measured in an adiabatic calorimeter with the electrical energy input controlled by the experimenter. It is usually desirable for the temperature to rise at a rate of $1 \mathrm{deg}$ $\min ^{-1}$ or less to permit attainment of thermal equilibrium between the sample and the calorimeter proper. With plutonium or its compounds the internal energy generation rate is constant, and at low temperatures where the system heat capacity is small, the temperature rise rate is too fast to allow accurate data to be obtained. The problem is principally one of thermal equilibration and will be worse with materials of low thermal conductivity such as $\mathrm{PuO}_{2}$ than with better conductors such as $\mathrm{Pu}$ metal. It is therefore suggested that $\mathrm{PuO}_{2}$ be diluted with a good heat conductor to minimize the effect of temperature gradients both within the sample and to the container, or plutonium isotopes with much longer half-life times ( ${ }^{242} \mathrm{Pu}$ or preferably ${ }^{244} \mathrm{Pu}$ ) be used. Approximate figures for the centre temperature of a pure $\mathrm{PuO}_{2}$ sample can be obtained by applying the differential equation for heat flow. Uncertainty in this approximation comes mainly from insufficient knowledge of the thermal conductivity of the sample in the low-temperature range. The effect of the self-heat is thus to set a temperature limit below which heat capacity data are difficult to obtain. Up to now, with ordinary plutonium, this limit appears to be about $10-15^{\circ} \mathrm{K}$. With many materials magnetic and other ordering effects are found in the heat capacity below $10^{\circ} \mathrm{K}$, and they contribute substantially to the absolute entropy. Such so-called anomalies in plutonium compounds are very likely to be difficult to measure precisely.

3.1.1.3. Radiation self-damage. As a consequence of the production of highly energetic alpha particles and nuclear interactions created the refrom (e.g. $\alpha-n)$, a large number of defects is induced in the $\mathrm{PuO}_{2}$ lattice. These defects may be present either as single point defects or as clusters of defects. An illustrative example of the effect of this phenomenon is given below.

The volume fraction affected by the passage of alpha particles can be calculated in a simple way by using the following formula:

$$
f_{v o l}=1-e^{-N v}
$$

where $\mathrm{N}$ is the number of alpha particles and $\mathrm{v}$ is the volume of an alphaparticle track. Reasonable values for the track dimensions of an alpha particle in $\mathrm{PuO}_{2}$ are $100 \AA$ diam. and $1000 \AA$ length $\left(\mathrm{v} \approx 8 \times 10^{-17} \mathrm{~cm}^{3}\right)$. Introducing these values in the above expression one finds that $\sim 50 \%$ of the volume will be affected by the tracks after $9 \times 10^{15}$ disintegrations 
TABLE VI. LOW-TEMPERA TURE HEA T CAPACITY OF $\mathrm{PuO}_{2}$

\begin{tabular}{ll|lc|lc}
\hline $\left.\mathrm{T}^{\circ} \mathrm{K}\right)$ & $\begin{array}{c}\mathrm{C}_{\mathrm{p}} \\
\text { (ca)/mole deg K) }\end{array}$ & $\mathrm{T}\left({ }^{\circ} \mathrm{K}\right)$ & $\begin{array}{c}\mathrm{C}_{\mathrm{P}} \\
\text { (cal/mole deg K) }\end{array}$ & $\mathrm{T}\left({ }^{\circ} \mathrm{K}\right)$ & $\begin{array}{c}\mathrm{C}_{\mathrm{p}} \\
\text { (ca1/mole deg K) }\end{array}$ \\
\hline 13 & 0.24 & 100 & 6.4 & 210 & 12.4 \\
15 & 0.29 & 110 & 7.0 & 220 & 12.9 \\
20 & 0.48 & 120 & 7.6 & 230 & 13.4 \\
25 & 0.80 & 130 & 8.1 & 240 & 13.9 \\
30 & 1.13 & 140 & 8.7 & 250 & 14.4 \\
35 & 1.42 & 150 & 9.3 & 260 & 14.9 \\
40 & 1.80 & 160 & 9.8 & 270 & 15.3 \\
45 & 2.22 & 170 & 10.4 & 280 & 15.7 \\
50 & 2.62 & 180 & 10.9 & 290 & 16.1 \\
60 & 3.42 & 190 & 11.4 & 300 & 16.5 \\
70 & 4.20 & 200 & 12.0 & 298.15 & 16.4 \\
90 & 5.67 & & & & \\
\hline
\end{tabular}

(4 d) and $90 \%$ after $3 \times 10^{16}$ decays $(14 \mathrm{~d})$. Calculation following the formula of Kinchin and Pease [78] gives 40 defects per alpha particle and about 1700 defects per uranium recoil atom. The presence of a high number of lattice defects will affect to a certain extent the vibrational spectrum of the lattice and hence influence the heat capacity.

In metals such as $\mathrm{Pu}$ the lattice defects produced by the alpha particles and recoiling atom can be annealed at relatively low temperatures [79]. In most metal oxides, however, the defects are more permanent and less easily removed by annealing processes. Radiation self-damage also causes the lattice parameter of plutonium compounds to increase, even at room temperature, and measurements on damaged samples [60] indicate that this damage does not anneal out until about $1000^{\circ} \mathrm{C}$. It is obviously important to make heat capacity measurements on radioactive samples as soon as possible after preparation or annealing.

Nevertheless, some damage will always be present at very low temperatures, and this will affect the measured heat capacities in two ways. Firstly, the heat capacity itself will be changed by the modification of the lattice vibrational spectrum arising from the defect concentration; quantitatively this effect is likely to be fairly small in samples that are not too heavily damaged. Secondly, the energy stored in the defects will be evolved as they anneal on warming; this will give measured $C_{p}$ values which are lower than the true values. In addition, of course, the selfdamage may interfere with any ordering processes that would normally occur (see below).

3.1.1.4. Heat capacity measurements. Measurements of the heat capacity of $\mathrm{PuO}_{2}$ below $325^{\circ} \mathrm{K}$ have been reported by Sandenaw [80]. The 


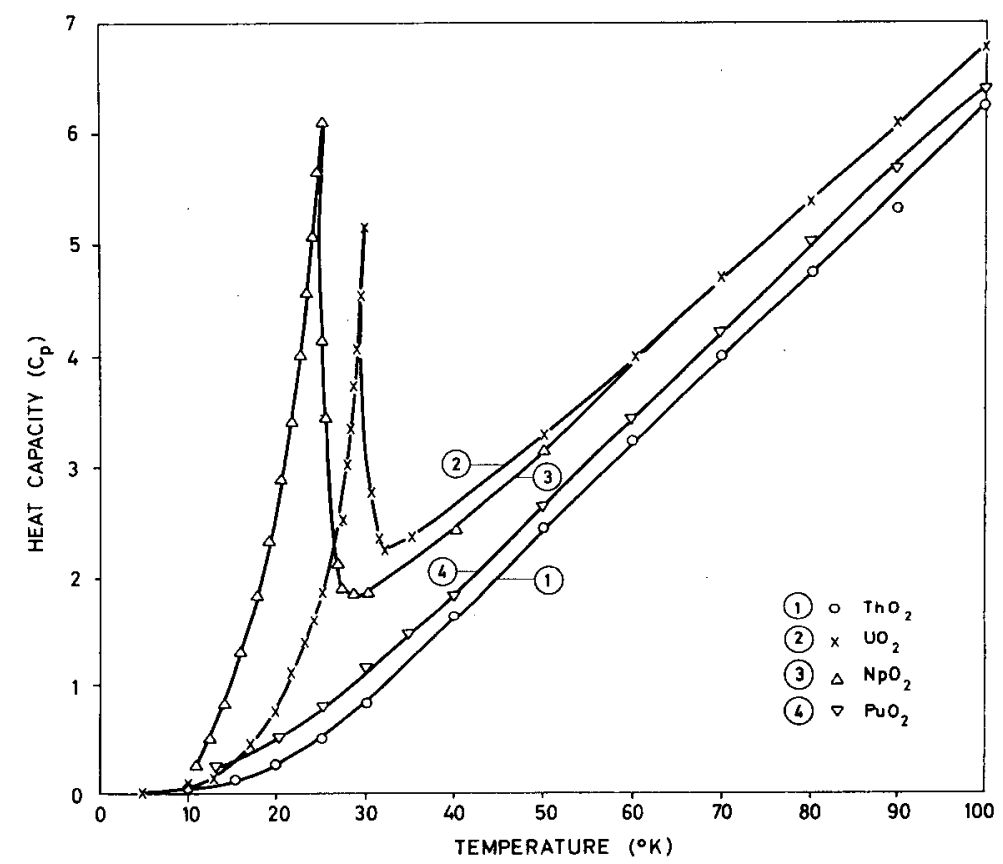

FIG.3. Experimental low-temperature heat capacities of $\mathrm{ThO}_{2}, \mathrm{UO}_{2}, \mathrm{NpO}_{2}$ and $\mathrm{PuO}_{2}$.

results showed some anomalous and irreproducible effects. In the first temperature cycle two peaks appeared around 34 and $69^{\circ} \mathrm{K}$ in the heat capacity curve. These humps gradually disappeared on further cycling and after the seventh cycle a heat capacity curve free from any peak was obtained. These data are tabulated in Table VI and represented in Fig. 3 where the values for $\mathrm{ThO}_{2}[81], \mathrm{UO}_{2}[1,82]$ and $\mathrm{NpO}_{2}$ [83] are included for comparison. Sandenaw assumed this curve to be the correct one for very slightly substoichiometric $\mathrm{PuO}_{2}$, but it is now clear that the increased lattice parameter $(5.403 \AA)$ of the material was a consequence of selfdamage, which causes the lattice parameter of stoichiometric $\mathrm{PuO}_{2}$ to increase from 5.396 to $5.414 \AA$ at saturation [60]. The above values therefore refer to a substantially damaged $\mathrm{PuO}_{2}$. The effect of such damage on the heat capacities in general will first be discussed, followed by a consideration of a possible magnetic ordering phenomenon.

TABLE VII. DEBYE TEMPERATURE $\left({ }^{\circ} \mathrm{K}\right)$

\begin{tabular}{ccccc}
\hline Substance & Elastic moduli & Intensity measurements & Mean & Reference \\
\hline & 417 & 393 & 405 & {$[84,85]$} \\
$\mathrm{ThO}_{2}$ & 388 & 377 & 382 & {$[84,85]$} \\
$\mathrm{UO}_{2}$ & - & 415 & 415 & {$[86]$} \\
$\mathrm{PuO}_{2}$ & & & & \\
\hline
\end{tabular}


Debye temperatures measured from X-ray or neutron diffraction intensity measurements, or calculated from elastic constants, can be used to estimate values of the heat capacity. Table VII shows that the calculated values for the Debye temperatures of $\mathrm{ThO}_{2}$ and $\mathrm{UO}_{2}$ are reasonably consistent, although a value of $870^{\circ} \mathrm{K}$ for $\mathrm{UO}_{2}$ has been deduced from thermal conductivity measurements.

Comparison of the $C_{V}$ values calculated from these mean Debye temperatures with experimental $\mathrm{C}_{\mathrm{p}}$ values for $\mathrm{UO}_{2}$ and $\mathrm{ThO}_{2}$ (the fact that $\mathrm{C}_{\mathrm{p}}$ and $\mathrm{C}_{\mathrm{v}}$ have different values is unimportant) shows the same behaviour. The calculated values are slightly lower than the experimental at $50^{\circ} \mathrm{K}$, but are considerably higher (by up to $2.5 \mathrm{cal}$ deg $\mathrm{K}^{-1}$ mole -1 ) above $50^{\circ} \mathrm{K}$. Since exactly the same behaviour is found for $\mathrm{PuO}_{2}$ (see Fig. 4), we may have confidence that Sandenaw's values in general are not greatly in error. The discussion in Section II.1.3. implies, however, that they are likely to be slightly low, as Sandenaw recognized.

In a more recent interpretation of the $\mathrm{UO}_{2}$ neutron diffraction data [1], Willis has analysed the lattice heat capacity in terms of a Debye acoustical branch associated with the vibrations of the uranium sub-lattice (Debye temperature $\square 182^{\circ} \mathrm{K}$ ) and an Einstein optical branch associated with the oxygen sub-lattice (Einstein temperature $=542^{\circ} \mathrm{K}$ ). This representation leads to excellent agreement with the experimental heat capacity values, and with the lattice entropy at $25^{\circ} \mathrm{C}$ (calculated $=17.3$, experimental $=17.5$ e.u. ). A similar neutron diffraction study of $\mathrm{PuO}_{2}$ is thus a possible method of deriving heat capacities and entropies for $\mathrm{PuO}_{2}$. The heat capacity curves for $\mathrm{UO}_{2}$ and $\mathrm{NpO}_{2}$ contain a lambdatype peak near $30^{\circ} \mathrm{K}$, which has been shown, for $\mathrm{UO}_{2}$ at least [1], to be caused by an antiferromagnetic ordering of the electron spins. Since the plutonium atom in $\mathrm{PuO}_{2}$ has four $5 f$ electrons, a similar, indeed more pronounced, peak could be expected in $\mathrm{PuO}_{2}$.

It is impossible to infer from Sandenaw's data whether such a peak occurs in the undamaged $\mathrm{PuO}_{2}$, since the several "spikes" seen in the first runs were also found in his heat capacity curve for plutonium metal, where the latest data $[87,88]$ indicate a smooth curve free from anomalies. It is thus possible that they were experimental artefacts, although it is tempting to attribute the peak near $34^{\circ} \mathrm{K}$ to a magnetic ordering. Conversely, there are a number of possible explanations for the absence of the peak in the self-damaged sample. In addition to the possibility of destruction of the long-range order by the self-damage, the lambda peak may have been below $12^{\circ} \mathrm{K}$, the lowest temperature measured, which again may not have been the true temperature because of self-heat.

A brief progress report [89] claims that no magnetic ordering could be found by neutron diffraction in ${ }^{242} \mathrm{PuO}_{2}$. It is obviously essential to confirm this somewhat surprising behaviour, and a convenient and relatively simple measurement would be the magnetic susceptibility of $\mathrm{PuO}_{2}$ down to these temperatures, since $\mathrm{dXm} / \mathrm{dT}$ changes extremely rapidly near an antiferromagnetic transition. Dawson [90] has measured the magnetic susceptibility of $\mathrm{PuO}_{2}$, but down to $90^{\circ} \mathrm{K}$ only. At room 


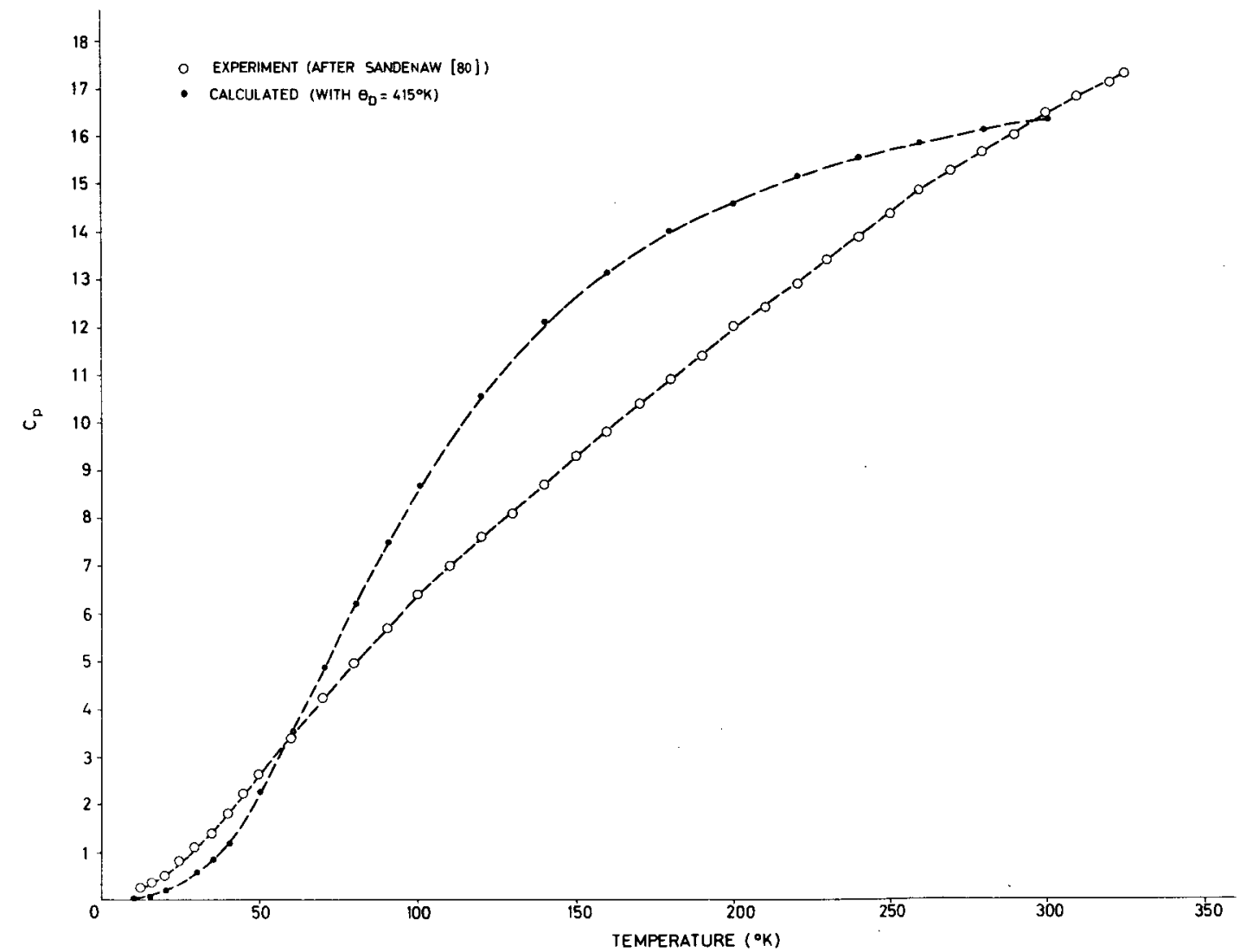

FIG. 4. Experimental and calculated heat capacities of $\mathrm{PuO}_{2}$. 
temperature $\mathrm{X}_{\mathrm{M}}$ for $\mathrm{PuO}_{2}$ is much smaller than the value expected for a $5 \mathrm{f}^{4}$ ion; this may be due to magnetic interactions, however, since the value extrapolated from dilute $\mathrm{PuO}_{2}-\mathrm{ThO}_{2}$ solid solutions is much higher, and is close to the expected $5 f^{4}$ value.

3.1.1.5. Entropies. The lattice contribution to standard entropies at $25^{\circ} \mathrm{C}$ canbe estimated from the Debye temperatures discussed in the previous section; like the heat capacity values, it is too high for $\mathrm{ThO}_{2}$ and $\mathrm{UO}_{2}$ by 4.0 and 2.7 e.u. respectively. Since the value for $\mathrm{PuO}_{2}$ calculated from a Debye temperature of $415^{\circ} \mathrm{K}$ is $18.8 \mathrm{e} . \mathrm{u}$., the correct value is probably around 16.0 e.u. , in good agreement with Sandenaw's measured value of $16.3 \mathrm{e}$.u. If it is assumed that magnetic ordering must exist, one can add $R \ln 5=3.2$ e.u. to Sandenaw's value to give $\mathrm{S}_{298}^{\circ}=19.5 \mathrm{e} . \mathrm{u}$. This may be a little low because of the effects of stored energy release on the measured heat capacities.

Two other estimates are available from the literature for the entropy of $\mathrm{PuO}_{2}$ at $298^{\circ} \mathrm{K}$. The first by Osborne and Westrum [81] is based on the measured entropies of $\mathrm{ThO}_{2}, \mathrm{UO}_{2}$ and $\mathrm{NpO}_{2}$. Osborne and Westrum argue that the magnetic contribution to the entropy can be approximated by the spin-only contribution as computed from the number of unpaired $5 \mathrm{f}$ electrons in $\mathrm{Np}^{+4}$ and $\mathrm{U}^{+4}$. $\mathrm{Th}^{+4}$ has no unpaired electrons and hence is diamagnetic and shows no magnetic ordering. The entropy of $\mathrm{ThO}_{2}$ is thus purely lattice entropy. They then observe that the excess entropy of $\mathrm{UO}_{2}$ and $\mathrm{NpO}_{2}$ over the lattice entropy (assumed to be the same as $\left.\mathrm{ThO}_{2}\right)$ is equal to $\mathrm{R} \ln (2 \mathrm{~S}+1)+0.85$ where $\mathrm{S}$ is the spin quantum number for the appropriate number of $5 f$ electrons, and 0.85 is a constant presumed to include any electronic entropy. For $\mathrm{PuO}_{2}$ the estimated entropy is: $\mathrm{S}_{298}^{\circ}=19.7 \mathrm{e} . \mathrm{u}$.

In a later paper Westrum and Gr $\phi$ nvold [91] provide another estimate based upon a study of the systematics of the transition metal chalcogenides. Here, following Latimer, they assume a constant contribution of $15.0 \mathrm{e}$. u. for any actinide cation, plus a contribution of $2.0 \mathrm{e} . \mathrm{u}$. from the two oxygen atoms, plus the $\mathrm{R} \ln (2 \mathrm{~S}+1)$ magnetic contribution as above. The result for $\mathrm{PuO}_{2}$ is $\mathrm{S}_{298}^{\circ}=20.2 \mathrm{cal} / \mathrm{degK}$ gfw. Also in this paper Westrum and Gr $\phi$ nvold offer a useful procedure for estimating the entropies of oxides other than the dioxide.

The close agreement between Osborne and Westrum's estimate (19.7. e.u.) and Sandenaw's modified value (19.5 e.u.), which is expected to be slightly low, leads us to adopt a value of $19.7 \pm 1.0 \mathrm{e} . \mathrm{u}$. for the standard entropy of $\left\langle\mathrm{PuO}_{2}\right\rangle$, and to modify Westrum and Gr $\phi$ nvold's calculations for the other oxides as shown in Table VIII.

The oxygen contributions are taken from Westrum and Gr $\phi$ nvold's table [91], which was derived from a consideration of many transition metal oxides. The magnetic contributions are the spin-only term, $\mathrm{R}$ ln $(2 \mathrm{~S}+1)$, assuming that $\mathrm{Pu}^{+3}$ has five $5 f$ electrons and $\mathrm{Pu}^{+4}$ has four. In $\mathrm{PuO}_{1.61}$ it is assumed that the unit cell contains $24 \mathrm{Pu}+3$ and $8 \mathrm{Pu}^{+4}$ ions.

Despite the plausibility of this estimation scheme the results are probably only accurate to $\pm 10 \%$. 
TABLE VIII. ESTIMA TION OF ENTROPIES OF PLUTONIUM OXIDES

\begin{tabular}{l|c|c|c|c}
\hline \multirow{2}{*}{ Phase } & \multicolumn{2}{|c|}{ S lattice } & S magnetic & $\mathrm{S}_{298}^{\circ}$ \\
& \multicolumn{2}{c|}{$\begin{array}{c}\mathrm{Pu} \\
\text { contribution }\end{array}$} & $\begin{array}{c}\text { conteg K gfw } \\
\text { contribution }\end{array}$ & \\
\hline hex $-\mathrm{Pu}_{2} \mathrm{O}_{3}$ & 29.0 & 0 & $2 \times 3.6$ & 36.2 \\
cubic- $\mathrm{PuO}_{1.52}$ & 14.5 & 0 & 3.6 & 18.1 \\
$\mathrm{PuO}_{1.61}$ & 14.5 & 0.9 & 3.5 & 18.9 \\
$\mathrm{PuO}_{2}$ & 14.5 & 2 & 3.2 & 19.7 \\
\hline
\end{tabular}

\subsubsection{High-temperature heat capacities}

3.1.2.1. Plutonium dioxide, $\mathrm{PuO}_{2}$. Sandenaw [80] finds $\mathrm{C}_{\mathrm{p}}=16.5 \mathrm{cal}$ degK $\mathrm{K}^{-1}$ mole $\mathrm{e}^{-1}$ at $300^{\circ} \mathrm{K}$, as already discussed. Rand [70], on the basis of work done at Brussels [92], suggests the equation

$$
\mathrm{C}_{\mathrm{p}}=19.34+1.56 \times 10^{-3} \mathrm{~T}-2.8 \times 105 \mathrm{~T}^{-2} \mathrm{cal} \mathrm{degK}^{-1} \mathrm{~mole}^{-1}
$$

for the temperature range 300 to $1000^{\circ} \mathrm{K}$, which also agrees quite well with Sandenaw's value at $300^{\circ} \mathrm{K}$. Here we shall use Rand's equation with an estimated uncertainty of $5 \%$ which is assumed to be in the first term, amounting to $1.0 \mathrm{cal} \mathrm{deg} \mathrm{K}^{-1} \mathrm{~mole}^{-1}$.

3.1.2.2. Hexagonal $\mathrm{Pu}_{2} \mathrm{O}_{3}$. To estimate the heat capacity of this compound we assume that

$$
2 \mathrm{C}_{\mathrm{p}}\left\langle\mathrm{PuO}_{2}\right\rangle-\mathrm{C}_{\mathrm{p}}\left\langle\mathrm{Pu}_{2} \mathrm{O}_{3}\right\rangle \text { hex }=2 \mathrm{C}_{\mathrm{p}}\left\langle\mathrm{CeO}_{2}\right\rangle-\mathrm{C}_{\mathrm{p}}\left\langle\mathrm{Ce}_{2} \mathrm{O}_{3}\right\rangle \text { hex }
$$

The values for $\left\langle\mathrm{CeO}_{2}\right\rangle$ are taken from King and Christiansen [93], and those for $\left\langle\mathrm{Ce}_{2} \mathrm{O}_{3}\right\rangle$ are from Pankratz and Kelley [94]. It is noticed that between 300 and $1000^{\circ} \mathrm{K}$ the difference $2 \mathrm{C}_{\mathrm{p}}\left\langle\mathrm{CeO}_{2}\right\rangle-\mathrm{C}_{\mathrm{p}}\left\langle\mathrm{Ce}_{2} \mathrm{O}_{3}\right\rangle$ hex is constant within a few tenths of a unit at approximately 2.1. Therefore, the value for $\left\langle\mathrm{Pu}_{2} \mathrm{O}_{3}\right\rangle$ hex is taken to be

$$
\mathrm{C}_{\mathrm{p}}\left\langle\mathrm{Pu}_{2} \mathrm{O}_{3}\right\rangle_{\text {hex }}=2 \mathrm{C}_{\mathrm{p}}\left\langle\mathrm{PuO}_{2}\right\rangle-(2.1 \pm 1.0) \mathrm{cal} \mathrm{degK}^{-1} \text { mole }-1
$$

where the rather large uncertainty is assumed because of the somewhat different results obtained by Kuznetsov and Rezukhina [95]. Thus we have

$$
\mathrm{C}_{\mathrm{p}}\left\langle\mathrm{Pu}_{2} \mathrm{O}_{3}\right\rangle_{\text {hex }}=(36.6 \pm 2.3)+3.12 \times 10^{-3} \mathrm{~T}-5.6 \times 10^{5} \mathrm{~T}^{-2} \mathrm{cal} \mathrm{deg} \mathrm{K}-1 \mathrm{~mole}^{-1}
$$

3.1.2.3. Cubic $\left\langle\mathrm{PuO}_{1.52}\right\rangle$. The heat capacity of cubic $\left\langle\mathrm{PuO}_{1.52}\right\rangle$ is estimated by ignoring the deviation from stoichiometry and examining 
TABLE IX. HEA T CAPACITIES OF RARE-EARTH OXIDES (cal deg $\mathrm{K}^{-1}$ mole $^{-1}$ )

\begin{tabular}{|c|c|c|c|c|c|c|c|}
\hline \multirow{2}{*}{$T\left(^{*} \mathrm{~K}\right)$} & \multicolumn{3}{|c|}{ a-hex } & \multicolumn{3}{|c|}{ c-cubic } & \multirow{2}{*}{ Reference } \\
\hline & 300 & 500 & 1000 & 300 & 500 & 1000 & \\
\hline $\mathrm{La}_{2} \mathrm{O}_{3}$ & 25.8 & 29.0 & 31.7 & & & & [96] \\
\hline $\mathrm{Ce}_{2} \mathrm{O}_{3}$ & 27.5 & 32.2 & 35.3 & & & & [94] \\
\hline $\mathrm{Pr}_{2} \mathrm{O}_{3}$ & 28.2 & 31.2 & 35.0 & & & & [97] \\
\hline $\mathrm{Nd}_{2} \mathrm{O}_{3}$ & 26.8 & 30.2 & 34.6 & & & & [98] \\
\hline $\mathrm{Sm}_{2} \mathrm{O}_{3}$ & & & & 27.8 & 31.6 & 35.3 & [98] \\
\hline $\mathrm{Eu}_{2} \mathrm{O}_{3}$ & & & & 29.8 & 32.9 & 36.0 & [98] \\
\hline $\mathrm{GC}_{2} \mathrm{O}_{3}$ & & & & 25.2 & 28.5 & 31.1 & [98] \\
\hline $\mathrm{Tb}_{2} \mathrm{O}_{3}$ & & & & 27.7 & 30.5 & 33.9 . & [97] \\
\hline $\mathrm{Dy}_{2} \mathrm{O}_{3}$ & & & & 28.1 & 30.1 & 32.3 & [96] \\
\hline $\mathrm{Ho}_{2} \mathrm{O}_{3}$ & & & & 27.1 & 29.3 & 31.3 & [99] \\
\hline $\mathrm{Er}_{2} \mathrm{O}_{3}$ & & & & 25.3 & 28.9 & 31.2 & [99] \\
\hline $\operatorname{Tm}_{2} \mathrm{O}_{3}$ & & & & 27.4 & 30.0 & 31.5 & [99] \\
\hline $\mathrm{Yb}_{2} \mathrm{O}_{3}$ & & & & 27.3 & 30.4 & 31.8 & [99] \\
\hline $\mathrm{Lu}_{2} \mathrm{O}_{3}$ & & & & 23.4 & 27.9 & 30.5 & [94] \\
\hline Mean & 27.1 & 30.7 & 34.2 & 26.9 & 30.0 & 32.5 & \\
\hline $\mathrm{TbO}_{1,500}$ & 13.9 & 15.3 & 17.0 & & & & \\
\hline $\mathrm{TbO}_{1.719}$ & 14.1 & 16.1 & 18.5 & & & & \\
\hline $\mathrm{TbO}_{1,812}$ & 13.9 & 16.5 & 19.0 & & & & \\
\hline $\mathrm{PrO}_{1.500}$ & 14.1 & 15.6 & 17.5 & & & & \\
\hline $\mathrm{PrO}_{1.833}$ & 15.1 & 18.2 & 22.6 & & & & \\
\hline
\end{tabular}


the differences in the hexagonal and cubic rare-earth oxides as shown in Table IX. Unfortunately there are no measurements on the two forms of oxide for the same metal. From the table it is seen that the two oxides have nearly the same heat capacity at room temperature, differ by about $0.7 \operatorname{deg} \mathrm{K}$ at $500^{\circ} \mathrm{K}$, and by about $2 \operatorname{deg} \mathrm{K}$ at $1000^{\circ} \mathrm{K}$, with the hexagonal form having the higher heat capacity. Accordingly, for the reaction

$$
2\left\langle\mathrm{PuO}_{1.5}\right\rangle_{\text {cubic }}=\left\langle\mathrm{Pu}_{2} \mathrm{O}_{3}\right\rangle_{\text {hex }}
$$

the equation

$$
\Delta \mathrm{C}_{\mathrm{p}}=-0.8+3.0 \times 10^{-3} \mathrm{~T} \text { cal } \operatorname{deg} \mathrm{K}^{-1}
$$

is used. The uncertainty is estimated to be about $1 \mathrm{cal} \operatorname{deg} \mathrm{K}^{-1} \mathrm{~mole}^{-1}$. This gives

$$
C_{\mathrm{p}}\left\langle\mathrm{PuO}_{1.5}\right\rangle_{\text {cubic }}=(18.7 \pm 1.2)-2.8 \times 105 \mathrm{~T}^{-2} \mathrm{cal} \mathrm{deg} \mathrm{K}^{-1} \mathrm{~mole}^{-1}
$$

3.1.2.4. $\mathrm{PuO}_{1.61}$-cubic. An examination of $\mathrm{C}_{\mathrm{p}}$ for $\left\langle\mathrm{TbO}_{1.500}\right\rangle$, $\langle\overline{\mathrm{TbO}} 1.719\rangle$ and $\left\langle\mathrm{TbO}_{1.812}\right\rangle$ as well as $\left\langle\mathrm{PrO}_{1.500}\right\rangle$ and $\left\langle\mathrm{PrO}_{1.833}\right\rangle$ shows that the higher oxides have the higher heat capacities. It is noticed that the difference between $\left\langle\mathrm{TbO}_{1.500}\right\rangle$ and $\left\langle\mathrm{TbO}_{1.719}\right\rangle$ is about twice the difference between $\left\langle\mathrm{TbO}_{1.719}\right\rangle$ and $\left\langle\mathrm{TbO}_{1.812}\right\rangle$, which is thus assumed to be the difference between $\left\langle\mathrm{PuO}_{1.52}\right\rangle$ and $\left\langle\mathrm{PuO}_{1.61}\right\rangle$. It can be represented, with an uncertainty of about $0.3 \mathrm{cal}$ deg $\mathrm{K}^{-1} \mathrm{~mole}^{-1}$, by $\Delta \mathrm{C}_{\mathrm{p}}=8.0 \times 10^{-4} \mathrm{~T}$ cal $\operatorname{deg} \mathrm{K}^{-1} \mathrm{~mole}^{-1}$. From this

$\mathrm{C}_{\mathrm{p}}\left\langle\mathrm{PuO}_{1.61}\right\rangle_{\text {cubic }}=(18.7 \pm 1.3)+8.0 \times 10^{-4} \mathrm{~T}-2.8 \times 10^{5} \mathrm{~T}^{-2} \mathrm{cal} \mathrm{degK} \mathrm{K}^{-1} \mathrm{~mole}^{-1}$

\subsection{Heat of fusion}

No direct experimental data are available for the heat of fusion of $\mathrm{PuO}_{2}$, but liquidus-solidus measurements in the $\mathrm{UO}_{2}-\mathrm{PuO}_{2}$ system are consistent with a value of $16.8 \pm 1.3 \mathrm{kcal} \mathrm{mole}^{-1}$ (see Section III. 2.2).

\subsection{Calorimetric heats of formation}

The only plutonium oxide for which there are experimental heat of formation data is plutonium dioxide. This was measured by oxygen bomb calorimetry by Popov and Ivanov [100], who obtained $-252.1 \pm 1.1 \mathrm{kcal} / \mathrm{mole}$, and by Holley et al. [101], who obtained $-252.87 \pm 0.38 \mathrm{kcal} / \mathrm{mole}$. The results are thus in agreement and the weighted average is taken: $\Delta \mathrm{H}_{\mathrm{f}}^{\rho} 298$ $\left\langle\mathrm{PuO}_{2}\right\rangle=-252.8 \pm 0.8 \mathrm{kcal} / \mathrm{mole}$.

Experimental data for the other oxides are very desirable.

\subsection{High-temperature equilibria}

This section deals with the oxygen pressure measurements over the $\mathrm{Pu}_{2} \mathrm{O}_{3}-\mathrm{PuO}_{2}$ region at high temperatures. The main treatment is in 


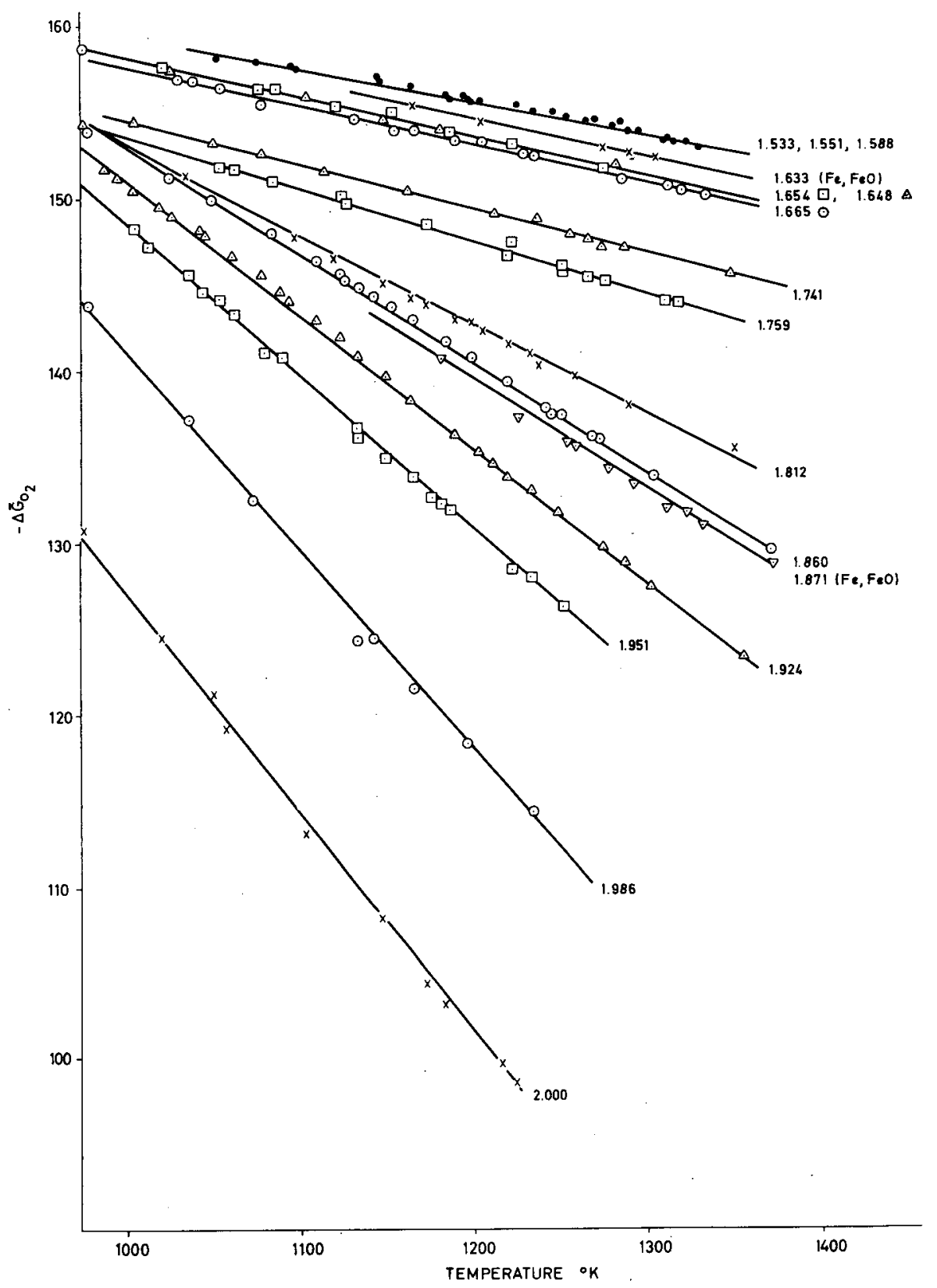

FIG. 5. Partial molar free energy of single-phase $\mathrm{PuO}_{2-\mathrm{x}}$.

31 
terms of the phase diagram given in Fig. 1, but other possible phase diagrams consistent with the data are also discussed.

\subsection{1. $\left\langle\mathrm{PuO}_{1.61}\right\rangle$ to $\left\langle\mathrm{PuO}_{2}\right\rangle$ region}

Above $945^{\circ} \mathrm{K}$ this region is single phase with a fluorite-type structure. Below approximately $945^{\circ} \mathrm{K}$, this phase disproportionates to $\left\langle\mathrm{PuO}_{1.61+y}\right\rangle$ and $\left\langle\mathrm{PuO}_{2-\mathrm{x}}\right\rangle$ at a temperature depending on the $\mathrm{O} / \mathrm{Pu}$ ratio.

Markin et al. [102] have measured the oxygen potentials over the single phase oxides between $\mathrm{PuO}_{1.61}$ and $\mathrm{PuO}_{2.0}\left(950\right.$ to $\left.1350^{\circ} \mathrm{K}\right)$, using an EMF method (Fig. 5). The extremely reducing conditions required the use of a $\mathrm{ThO}_{2}-\mathrm{Y}_{2} \mathrm{O}_{3}$ solid electrolyte which does not conduct oxygen below $950^{\circ} \mathrm{K}$. Therefore it was not possible to measure the oxidation potentials in the $\left\langle\mathrm{PuO}_{1.61+y}\right\rangle$ and $\left\langle\mathrm{PuO}_{2-\mathrm{x}}\right\rangle$ region. The free energy values from the corrected results of Atlas and Schleman [103] $\left(\mathrm{H}_{2} / \mathrm{H}_{2}\right.$ O equilibration, 1375 to $1575^{\circ} \mathrm{K}$ ) agree well with the EMF data where the temperature ranges overlap but the $\Delta \overline{\mathrm{H}}_{\mathrm{O}_{2}}$ and $\Delta \overline{\mathrm{S}}_{\mathrm{O}_{2}}$ values are markedly different. Bairiot and Vanhellemont [104] have made measurements on the $\mathrm{PuO}_{2-\mathrm{x}}-\mathrm{C}-\mathrm{CO}$ system at 1670 to $1870^{\circ} \mathrm{K}$; the derived $\Delta \bar{G}_{\mathrm{O}_{2}}$ values for $\mathrm{PuO}_{1.75}$ to $\mathrm{PuO}_{1.85}$ agree very well with the extrapolations of the EMF data, rather than the gas equilibration data. The compositional variations of $\Delta \overline{\mathrm{H}}_{\mathrm{O}_{2}}$ and $\Delta \overline{\mathrm{S}}_{\mathrm{O}_{2}}$ for the $\mathrm{AmO}_{2-\mathrm{x}}$ system, recently measured by gas equilibration by Chikalla et al. [105] and for the $\mathrm{CeO}_{2-\mathrm{x}}$ system by Bevan and Kordis [73], both again at temperatures below $1100^{\circ} \mathrm{C}$, are very similar to those found by Markin et al. for $\mathrm{PuO}_{2-\mathrm{x}}$. This difference in $\Delta \overline{\mathrm{H}}_{\mathrm{O}_{2}}$ and $\Delta \overline{\mathrm{S}}_{\mathrm{O}_{2}}$ for the two rather different temperature ranges may be real, since different defect types may predominate in the two cases. More free energy data for temperatures above $1100^{\circ} \mathrm{C}$ are clearly required. For the moment, however, the EMF values are preferred, note being taken that their extrapolation to higher temperatures may be subjected to some uncertainty.

The values obtained by interpolation of smoothed curves from Fig. 5 are given in Table $X$.

Figure 6 is a partial molar free energy diagram derived from this data. It can be seen that the values of $\Delta \overline{\mathrm{G}}_{\mathrm{O}_{2}}$ for $\mathrm{PuO}_{1.75}$ to $\mathrm{PuO}_{1.90}$ converge at $\sim 945^{\circ} \mathrm{K}$, which is therefore the point at which the two-phase region begins. This is in agreement with the phase diagram (Fig.1). The course of the $\mathrm{PuO}_{1.61+y}-\mathrm{PuO}_{2-\mathrm{x}}$ two-phase curve down to $800^{\circ} \mathrm{K}$ can be plotted by combining the isopleths for $\mathrm{PuO}_{1.65}$ to $\mathrm{PuO}_{1.75}$ with the phase diagram. A more accurate extrapolation to room temperature can be obtained by considering the integral values $\Delta \overline{\mathrm{H}}_{\mathrm{O}_{2}}$ and $\Delta \overline{\mathrm{S}}_{2}$ given in Section II. 3.5.

The data are insufficient to determine whether a miscibility gap is present, but do not conflict with the possibility of such a gap. The data presented in Fig. 5 show that in the range $1.648<\mathrm{O} / \mathrm{Pu}<1.665$ the partial molar free energy is constant to within $400 \mathrm{cal}$, the estimated experimental error, so that a two-phase region may be present in this oxygen composition range. Consideration of the X-ray data of Gardner et al. [13] gives the upper and lower limits of this region as $1.665<\mathrm{O} / \mathrm{Pu}<1.675$ and $1.633<\mathrm{O} / \mathrm{Pu}<1.648$ respectively. If this two-phase region exists then the free energy curve representing the two-phase region, $\left\langle\mathrm{PuO}_{1.61+y}\right\rangle$ 
TABLE X. PARTIAL MOLAR ENTROPIES AND ENTHALPIES OF SOLUTION OF OXYGEN IN $\left\langle\mathrm{PuO}_{2-\mathrm{x}}\right\rangle$

$\left(\left(\mathrm{O}_{2}\right)=2[\mathrm{O}] \mathrm{PuO}_{2-\mathrm{x}}\right)$

$\begin{array}{cccc}2-x \text { in } \mathrm{PuO}_{2-\mathrm{x}} & -\Delta \overline{\mathrm{S}}_{\mathrm{O}_{2}} & -\Delta \overline{\mathrm{H}}_{\mathrm{O}_{2}} & \begin{array}{c}\text { Temperature } \\ \text { range }\end{array} \\ & \text { (e. u. }) & (\mathrm{kcal} \mathrm{mole}) & \text { (' } \mathrm{K})\end{array}$

$\begin{array}{llll}1.63 & 20.8 & 179.5 & 750 \text { to } 1500 \\ 1.65 & 20.0 & 178.0 & 800 \text { to } 1500 \\ 1.70 & 20.8 & 176.0 & 885 \text { to } 1500 \\ 1.75 & 26.8 & 180.5 & 900 \text { to } 1500 \\ 1.80 & 40.0 & 192.5 & 925 \text { to } 1500 \\ 1.85 & 54.7 & 206.0 & 945 \text { to } 1500 \\ 1.90 & 69.3 & 219.8 & 945 \text { to } 1500 \\ 1.95 & 85.8 & 233.5 & 900 \text { to } 1500 \\ 1.98 & 96.4 & 241.0 & 900 \text { to } 1500\end{array}$

$+\left\langle\mathrm{PuO}_{2-\mathrm{x}}\right\rangle$ in Fig. 6, must be modified so that the intersection with the postulated two-phase miscibility gap is at a higher temperature than the intersections with the single-phase lines for $\mathrm{O} / \mathrm{Pu}>1.670$.

It is also possible that a miscibility gap could occur in the region $1.665<\mathrm{O} / \mathrm{Pu}<1.740$ but its precise location would have to be consistent with the X-ray data (Section II. 2.2.4).

3. 4.2. $\left\langle\mathrm{PuO}_{1.61+y}\right\rangle+\left\langle\mathrm{PuO}_{2-\mathrm{x}}\right\rangle$ two-phase region

The integrated data (Section II. 3.5) give the following values:

\begin{tabular}{|c|c|c|c|}
\hline \multirow[t]{2}{*}{$\mathrm{T}^{\circ} \mathrm{K}$} & \multicolumn{2}{|c|}{ Phase limits } & \multirow{2}{*}{$\frac{-\Delta \bar{G}_{O_{2}}}{\mathrm{kcal} \mathrm{mole}^{-1}}$} \\
\hline & Lower & Upper & \\
\hline 615 & 1.61 & 1.98 & 170.4 \\
\hline 700 & 1.62 & 1.98 & 166.5 \\
\hline 800 & 1.65 & 1.97 & 161.7 \\
\hline 900 & 1.75 & 1.95 & 156.7 \\
\hline
\end{tabular}

3. 4. 3. $\left\langle\mathrm{Pu}_{2} \mathrm{O}_{3}\right\rangle$ hex to $\left\langle\mathrm{PuO}_{1,61}\right\rangle$ region

The oxygen potential measurements by Markin et al. [102] for the over-all compositions $\mathrm{PuO}_{1.533}, \mathrm{PuO}_{1.551}$ and $\mathrm{PuO}_{1.588}$ with both $\mathrm{Ni} / \mathrm{NiO}$ 


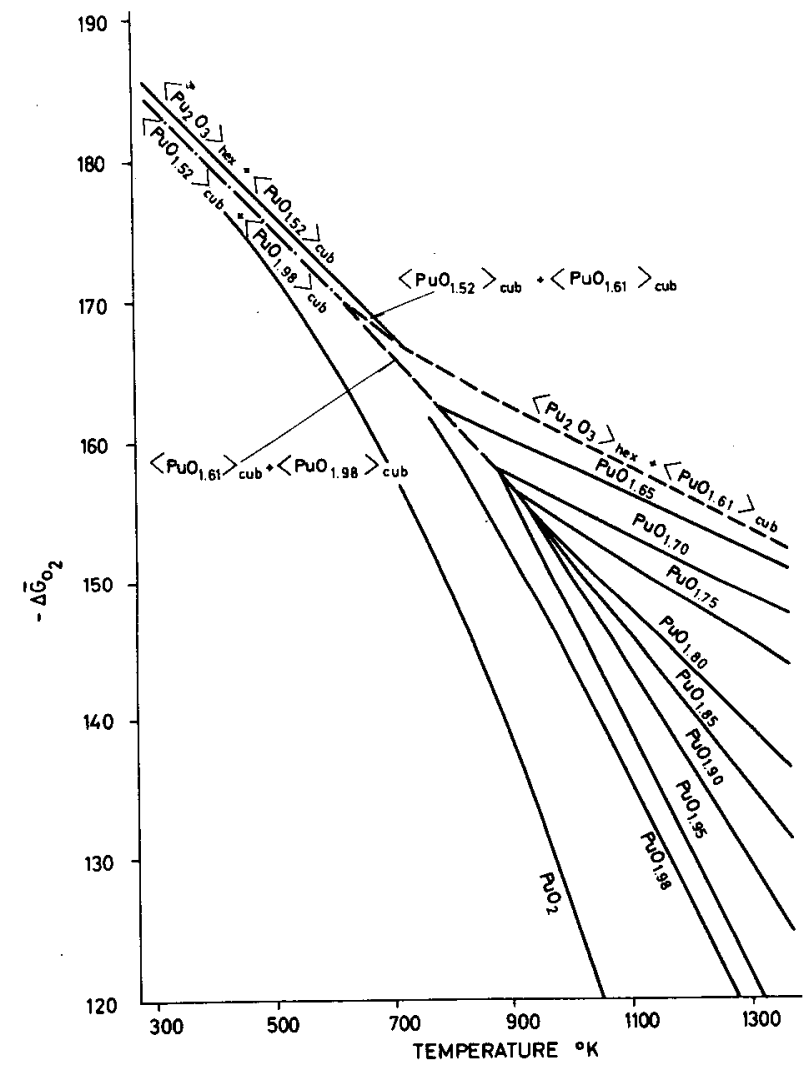

FIG.6. Partial molar free energy diagram derived from thermodynamic data and Pu-O phase diagram [102].

and $\mathrm{Fe} / \mathrm{FeO}$ reference electrodes give consistent results (Fig. 5). As discussed in the next section a positive $\Delta \overline{\mathrm{C}}_{\mathrm{p}}$ factor must be included and the final values obtained are:

Temperature

$\Delta \overline{\mathrm{S}}_{\mathrm{O}_{2}}$

e. u.

$\left\langle\mathrm{Pu}_{2} \mathrm{O}_{3}\right\rangle_{\text {hex }}+\left\langle\mathrm{PuO}_{1.61}\right\rangle$

$\left\langle\mathrm{PuO}_{1.52}\right\rangle_{\text {cub }}+\left\langle\mathrm{PuO}_{2-\mathrm{x}}\right\rangle$

$$
\overline{70.8-16.1 \log \mathrm{T}}
$$

46.0
$\Delta \overline{\mathrm{H}}_{\mathrm{O}_{2}}$ kcal mole -1

$\overline{189500-7.0 \mathrm{~T}}$ 198700 range

$\left({ }^{\circ} \mathrm{K}\right)$ 298 to 610

\section{5. Integration of partial molar quantities}

The partial molar heats and entropies for the entire region from $\left\langle\mathrm{Pu}_{2} \mathrm{O}_{3}\right\rangle_{\text {hex }}$ to $\left\langle\mathrm{PuO}_{2}\right\rangle$ can now be integrated according to the equation

$$
\Delta \mathrm{Z}=2 \int_{1.5}^{2} \Delta \bar{Z}_{\mathrm{O}_{2}} \mathrm{dx}
$$


where $x=O / P u$ and $Z=H$ or $S$. The values obtained are

$$
\begin{gathered}
2\left\langle\mathrm{Pu}_{2} \mathrm{O}_{3}\right\rangle+\left(\mathrm{O}_{2}\right) \rightarrow 4\left\langle\mathrm{PuO}_{2}\right\rangle \\
\Delta \mathrm{H}_{1150}=-196.9 \text { kcal; } \Delta \mathrm{S}_{1150}=-43.0 \text { e.u. }
\end{gathered}
$$

In order to extrapolate these values to other temperatures, the heat capacities of $\left\langle\mathrm{Pu}_{2} \mathrm{O}_{3}\right\rangle$ hex and $\left\langle\mathrm{PuO}_{2}\right\rangle$ must be used. No experimental data are yet available but estimated values have beengiven in Section II.3.1.2. The present assessment (taken from [70]) was based on earlier heat capacity data for the cerium oxides, and assumed $\Delta C_{p}$ for the above reaction to be zero, rather than -3.6 e. u. as estimated in Section II. 3.1.2. However, since much calorimetric data (including entropies, heats of formation and high-temperatures heat capacities) are likely to appear in the near future, it seemed appropriate to the Panel to leave a reintegration of this region of the phase diagram until all these data are available and until the presence or absence of a miscibility gap in the phase diagram has been established. The assessment presented in this section is therefore not quite consistent with other data used, but the uncertainty introduced in the free energies is less than the precision with which they are known.

A preliminary extrapolation of the partial molar free energies to lower temperatures shows that the lines for $\mathrm{PuO}_{2.00}$ and $\mathrm{PuO}_{1.98}$ must bend over considerably between $1000^{\circ} \mathrm{K}$ and room temperature, in order not to intersect with the $\left\langle\mathrm{Pu}_{2} \mathrm{O}_{3}\right\rangle_{\text {hex }}+\left\langle\mathrm{PuO}_{1.61}\right\rangle$ two-phase line above $500^{\circ} \mathrm{K}$. (There is evidence from both $\mathrm{X}$-ray [13] and conductivity [67] measurements that the phase in equilibrium with $\left\langle\mathrm{PuO}_{1.61}\right\rangle$ and $\left\langle\mathrm{PuO}{ }_{1.52}\right\rangle_{\text {cub }}$ has less oxygen than $\mathrm{PuO}_{2}$.) This curvature may be associated with the fact that $\mathrm{PuO}_{2}$ can adsorb relatively large amounts of oxygen on its surface below $600^{\circ} \mathrm{C}[26]$. This absorption process would thus provide low-energy sites on oxides close to $\mathrm{PuO}_{2}$ at room temperature but not at high temperatures. Whatever the cause of this curvature, however, it corresponds to a rapid increase (numerical decrease) in $\Delta \overline{\mathrm{H}}_{\mathrm{O}_{2}}$ and $\Delta \overline{\mathrm{S}}_{\mathrm{O}_{2}}$ for compositions between $\mathrm{O} / \mathrm{Pu}=1.98$ and 2.00 .

A similar phenomenon has been found for the partial heats and entropies of the $\mathrm{UO}_{2+x}$ phase near the stoichiometric composition, and its origin is fully discussed in [1]. Briefly, this type of curve, having approximately the shape of an oblique $S$ near stoichiometric composition, is due to the approach of atomic order within a disordered solution. Until more detailed thermochemical data in the region near $\mathrm{PuO}_{2.0}$ are available, the curvature may provisionally be taken into account by introducing a corresponding $\Delta \overline{\mathrm{C}}_{\mathrm{p}}$ term, but it must be borne in mind that such a procedure is purely formal.

Since we have taken

$$
\Delta \mathrm{C}_{\mathrm{p}}=2 \int_{1.5}^{2} \Delta \overline{\mathrm{C}}_{\mathrm{p}} \mathrm{dx} \text { for } 2\left\langle\mathrm{Pu}_{2} \mathrm{O}_{3}\right\rangle_{\text {hex }}+\left(\mathrm{O}_{2}\right)=4\left\langle\mathrm{PuO}_{2}\right\rangle \text { as zero }
$$

at $750^{\circ} \mathrm{K}$, a positive value of $\Delta \overline{\mathrm{C}}_{\mathrm{p}}$ in some other part of the region must be incorporated in order to compensate for the negative value near 
$\mathrm{O} / \mathrm{Pu}=2.0 . \quad$ The following values are suggested:

$\begin{array}{cccc}\mathrm{O} / \mathrm{Pu} & 1.50 \text { to } 1.61 & 1.61 \text { to } 1.98 & 1.98 \text { to } 2.00 \\ \Delta \overline{\mathrm{C}}_{\mathrm{p}} \text { (e.u.) } & +7 & 0 & -38.5\end{array}$

We can calculate $\Delta \overline{\mathrm{S}}_{\mathrm{O}_{2}}$ and $\Delta \overline{\mathrm{H}}_{\mathrm{O}_{2}}$ for (i) the $\left\langle\mathrm{Pu}_{2} \mathrm{O}_{3}\right\rangle_{\text {hex }}+\left\langle\mathrm{PuO}_{1.61}\right\rangle$ two-phase region; (ii) the $\left\langle\mathrm{PuO}_{1.61+\mathrm{y}}\right\rangle$ single-phase region; and (iii) the $\left\langle\mathrm{PuO}_{1,98-\mathrm{z}}\right\rangle$ to $\left\langle\mathrm{PuO}_{2}\right\rangle$ single-phase region, at $900^{\circ} \mathrm{K}$, and the se values $c$ an be combined with the integral values of $\Delta \mathrm{S}_{900}$ and $\Delta \mathrm{H}_{900}$ for $2\left\langle\mathrm{Pu}_{2} \mathrm{O}_{3}\right\rangle_{\text {hex }}+\mathrm{O}_{2} \rightarrow 4\left\langle\mathrm{PuO}_{2}\right\rangle_{\text {cub }}$, which, with $\Delta \mathrm{C}_{\mathrm{p}}=\mathrm{O}$, are independent of temperature, to give $\Delta \overline{\mathrm{S}}_{\mathrm{O}_{2}}$ and $\Delta \overline{\mathrm{H}}_{\mathrm{O}_{2}}$ at $900^{\circ} \mathrm{K}$ for the two-phase region $\left\langle\mathrm{PuO}_{1.61+y}\right\rangle+\left\langle\mathrm{PuO}_{1.98-z}\right\rangle$. Similar calculations were made for temperatures of $800,700,615$ and $500^{\circ} \mathrm{K}$, the latter giving $\Delta \overline{\mathrm{S}}_{2}$ and $\Delta \overline{\mathrm{H}}_{\mathrm{O}_{2}}$ for the $\left\langle\mathrm{PuO}_{1.52}\right\rangle_{\text {cub }}+\left\langle\mathrm{PuO}_{1.98-\mathrm{z}}\right\rangle$ two-phase region. The entire partial molar free energy diagram can now be completed. It is very satisfactory to find that the intersections of the isopleths for $\mathrm{PuO}_{1.65}$ to $\mathrm{PuO}_{1.80}$ with the $\left\langle\mathrm{PuO}_{1.61+\mathrm{y}}\right\rangle+\left\langle\mathrm{PuO}_{2-\mathrm{x}}\right\rangle$ region reproduce with considerable accuracy the phase diagram obtained independently by Gardner et al [13].

3.5.1. Heat of formation and standard entropy of $\left\langle\mathrm{Pu}_{2} \mathrm{O}_{3}\right\rangle_{\text {hex }}$, $\left\langle\mathrm{PuO}_{1.52}\right\rangle_{\text {cub }}$ and $\left\langle\mathrm{PuO}_{1.61}\right\rangle$

3.5.1.1. $\left\langle\mathrm{Pu}_{2} \mathrm{O}_{3}\right\rangle_{\text {hex }}$. The integrated partial molar heats and entropies give

$$
\begin{aligned}
2\left\langle\mathrm{Pu}_{2} \mathrm{O}_{3}\right\rangle_{\text {hex }} & +\left(\mathrm{O}_{2}\right) \rightarrow 4\left\langle\mathrm{PuO}_{2}\right\rangle \\
\Delta \mathrm{H}_{1150} & =-196.9 \mathrm{kcal}, \Delta \mathrm{S}_{1150}=43.0 \mathrm{e} . \mathrm{u} .
\end{aligned}
$$

With the heat capacity values for the oxides estimated in Section II.3.1.2 (or more conveniently, the thermal data in Table XI) and the thermal data for oxygen [106], we find

$$
\begin{array}{ll}
\Delta \mathrm{H}_{1150}-\Delta \mathrm{H}_{298}=-3.15 \mathrm{kcal} & \Delta \mathrm{S}_{1150}-\Delta \mathrm{S}_{298}=-4.7 \mathrm{e} . \mathrm{u} . \\
\Delta \mathrm{H}_{298}=-193.75 \mathrm{kcal}, & \Delta \mathrm{S}_{298}=-38.3 \mathrm{e} . \mathrm{u} .
\end{array}
$$

and finally, using the discussed values for the heat of formation and standard entropy of $\mathrm{PuO}_{2}$,

$$
\begin{aligned}
& \Delta \mathrm{H}_{\mathrm{f}}^{0},\left\langle\mathrm{Pu}_{2} \mathrm{O}_{3}\right\rangle_{\text {hex }}=-408.7 \pm 3.0 \mathrm{kcal} \\
& \mathrm{S}_{298}^{0},\left\langle\mathrm{Pu}_{2} \mathrm{O}_{3}\right\rangle_{\text {hex }}-34.0 \pm 5.0 \mathrm{e} . \mathrm{u} .
\end{aligned}
$$

where the uncertainties include those of the $\mathrm{PuO}_{2}$ data, the partial molar data and the heat capacity data. 
3.5.1.2. $\left\langle\mathrm{PuO}_{1.61}\right\rangle$. The data for the $\left\langle\mathrm{Pu}_{2} \mathrm{O}_{3}\right\rangle$ hex $+\left\langle\mathrm{PuO}_{1.61}\right\rangle$ region give

$$
\begin{array}{r}
\left\langle\mathrm{Pu}_{2} \mathrm{O}_{3}\right\rangle+0.11\left(\mathrm{O}_{2}\right) \rightarrow 2\left\langle\mathrm{PuO}_{1.61}\right\rangle \\
\Delta \mathrm{H}_{1150}=-20.0 \mathrm{kcal}, \Delta \mathrm{S}_{1150}=-2.4 \text { e.u. }
\end{array}
$$

The thermal data (Table XI) give

$$
\Delta \mathrm{H}_{298}=-19.0 \mathrm{kcal}, \Delta \mathrm{S}_{298}=-1.0 \mathrm{e} . \mathrm{u} \text {. }
$$

so that finally,

$$
\begin{aligned}
& \Delta \mathrm{H}_{\mathrm{f}}^{0},\left\langle\mathrm{PuO}_{1.61}\right\rangle=-213.9 \pm 1.5 \mathrm{kcal} \\
& \mathrm{S}_{298}^{0}\left\langle\mathrm{PuO}_{1.61}\right\rangle=19.2 \pm 2.5 \mathrm{e.u} .
\end{aligned}
$$

3.5.1.3. $\left\langle\mathrm{PuO}_{1.52}\right\rangle_{\text {cub }}$. The standard entropy of this phase is assumed to be slightly greater than that of $\frac{1}{2}\left\langle\mathrm{Pu}_{2} \mathrm{O}_{3}\right\rangle_{\text {hex }}$ :

$$
\mathrm{S}_{298}^{0}=17.2 \pm 3.0 \mathrm{e.u} \text {. }
$$

The fact that the free energy of the reaction

$$
\left\langle\mathrm{PuO}_{1.61}\right\rangle=0.805\left\langle\mathrm{PuO}_{1.52}\right\rangle_{\mathrm{cub}}+0.195\left\langle\mathrm{PuO}_{1.98}\right\rangle
$$

changes sign from negative below $650^{\circ} \mathrm{K}$ to positive above $650^{\circ} \mathrm{K}$ may be used to fix the heat of formation of $\left\langle\mathrm{PuO}_{1.52}\right\rangle$ cub. The free energy of formation of $\mathrm{PuO}_{1.98}$ is calculated from that of $\left\langle\mathrm{PuO}_{2}\right\rangle$ (Table XI) and $\Delta \overline{\mathrm{G}}_{\mathrm{O}_{2}}$ values for the $\mathrm{PuO}_{2-\mathrm{x}}$ phase. A heat of formation of $-206.3 \mathrm{kcal}$ for $\left\langle\mathrm{PuO}_{1.52}\right\rangle_{\mathrm{cub}}$ gives values of $-420,-150$ and +140 cal for the free energy of the above disproportionation reaction at 400,600 and $800^{\circ} \mathrm{K}$, and a zero free energy at $704^{\circ} \mathrm{K}$.

As a check on this value for the heat of formation, we may calculate the free energy of the other disproportionation reaction

$$
\left\langle\mathrm{PuO}_{1.52}\right\rangle_{\mathrm{cub}} \rightarrow 0.409\left\langle\mathrm{Pu}_{2} \mathrm{O}_{3}\right\rangle+0.182\left\langle\mathrm{PuO}_{1.61}\right\rangle
$$

which changes sign from positive to negative as the temperature is increased through $700^{\circ} \mathrm{K}$. The data give values of +130 , +70 and $-30 \mathrm{cal}$ at 400,600 and $800^{\circ} \mathrm{K}$, with a zero free energy at $740^{\circ} \mathrm{K}$. Thus with

$$
\Delta \mathrm{H}_{\mathrm{f}}^{0}\left\langle\mathrm{PuO}_{1.52}\right\rangle_{\mathrm{cub}}=-206.3 \pm 2.5 \mathrm{kcal}
$$

the inter-relationships of the three phases near the sesquioxide composition are reproduced very accurately. The small discrepancies in the temperature of the disproportionations are removed by trivial changes in the values for the heats of formation. 
TABLE XI. THERMOCHEMICAL DATA FOR OXIDES

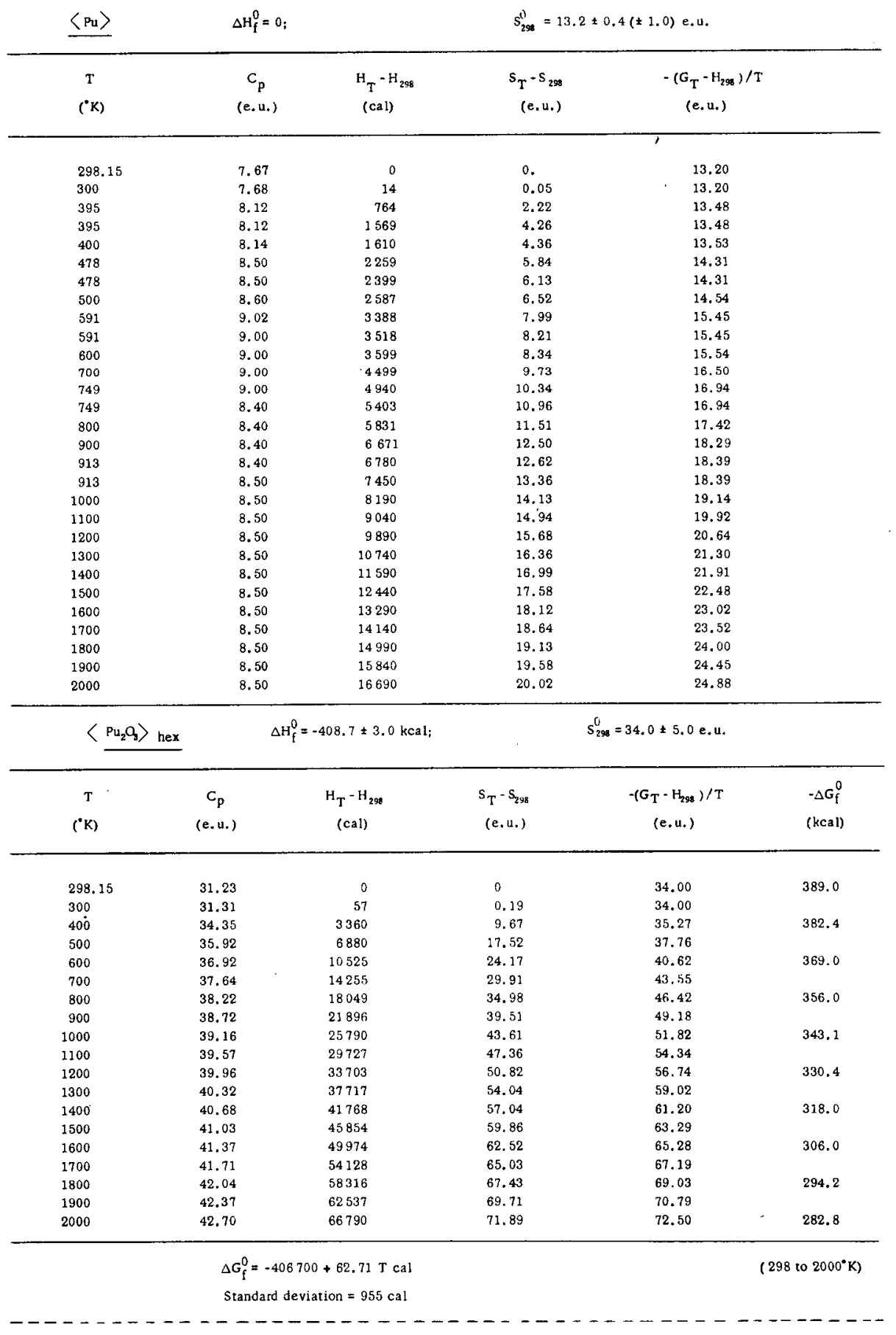


TABLE XI. (cont.)

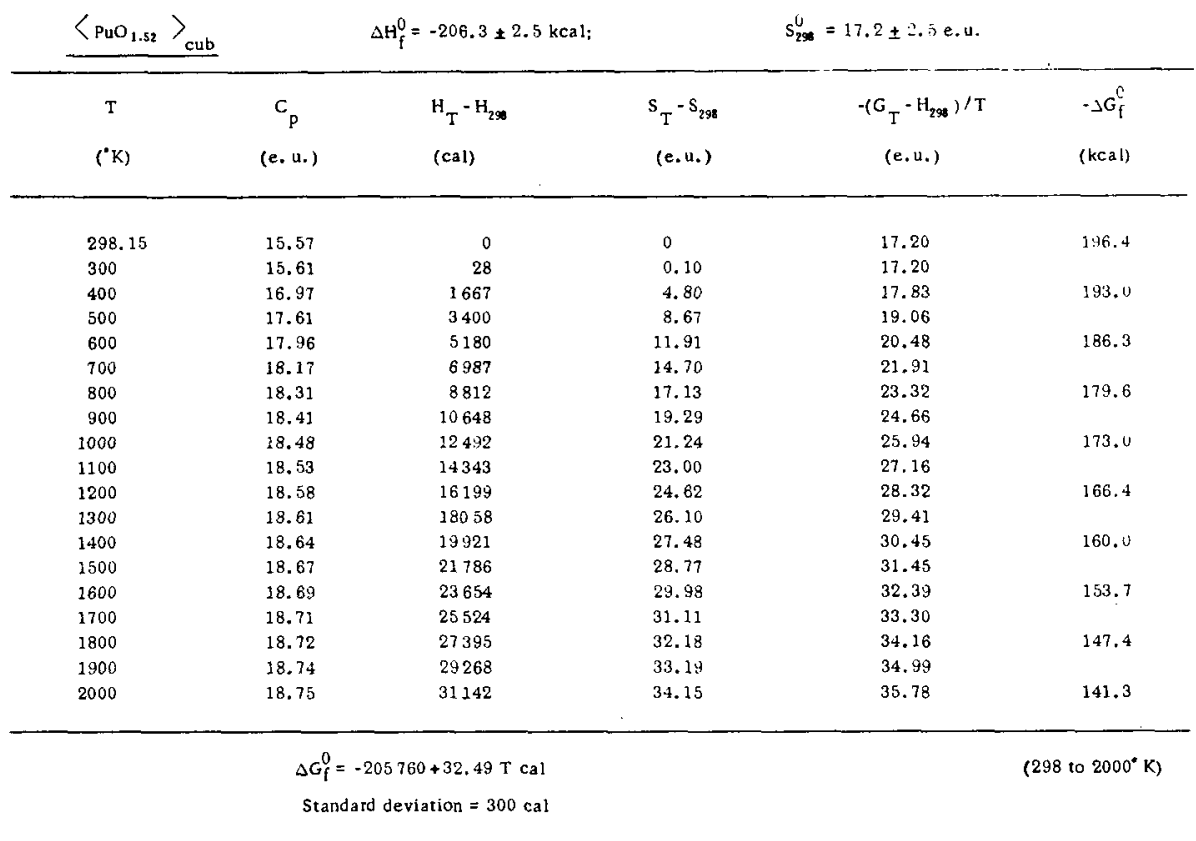

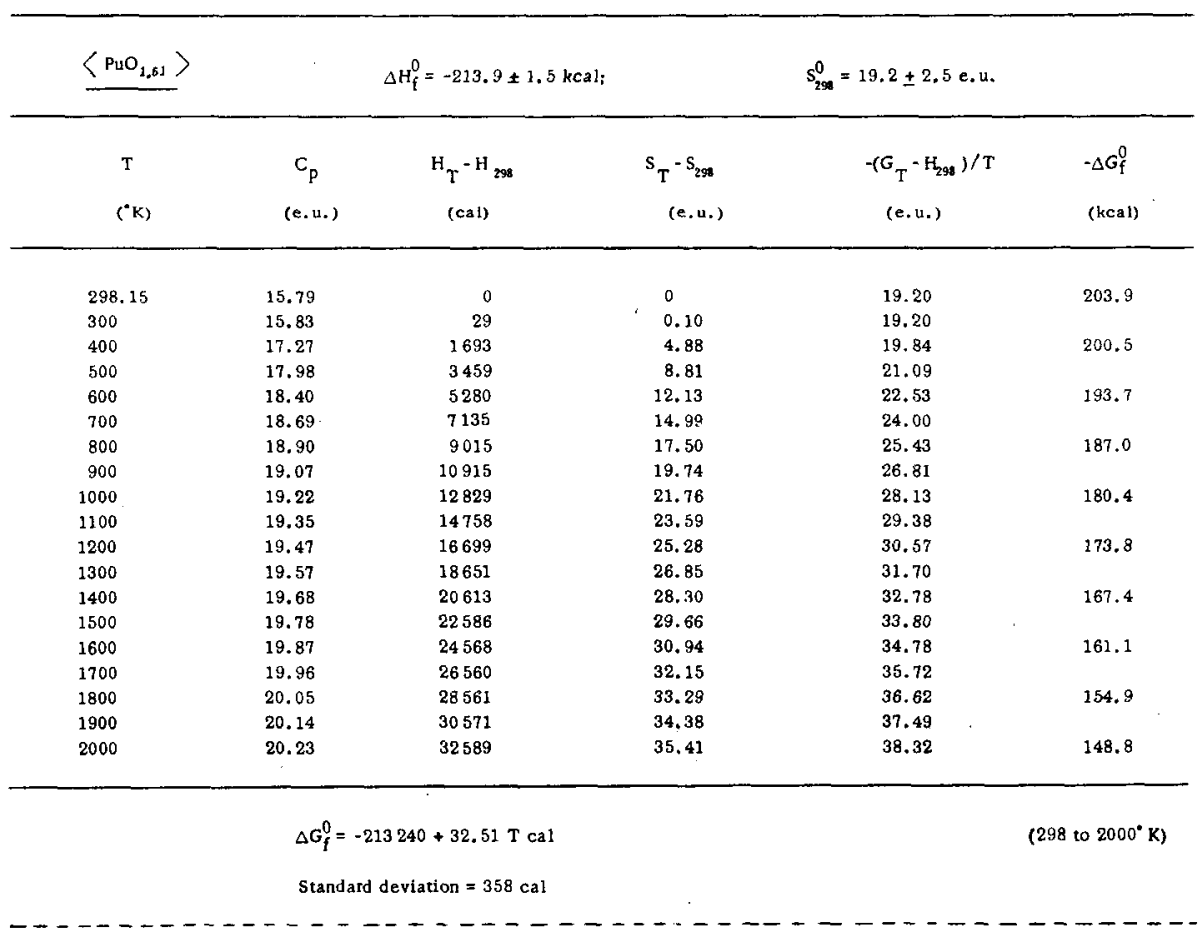


TABLE XI. (cont.)

$\left\langle\underline{\left.\mathrm{PuO}_{2}\right\rangle} \quad \Delta \mathrm{H}_{\mathrm{f}}^{0}=-252.8 \pm 0.8 \mathrm{kcal} ; \quad \mathrm{S}_{299}^{0}=19.7 \pm 1.0\right.$ e.u

\begin{tabular}{|c|c|c|c|c|c|}
\hline $\begin{array}{l}\mathrm{T} \\
(\mathrm{K})\end{array}$ & $\begin{array}{c}C_{p} \\
\text { (e.u.) }\end{array}$ & $\begin{array}{l}\mathrm{H}_{\mathrm{T}}-\mathrm{H}_{298} \\
\text { (cal) }\end{array}$ & $\begin{array}{l}\mathrm{S}_{T}-\mathrm{S}_{2998} \\
\text { (e.u.) }\end{array}$ & $\begin{array}{c}-\left(G_{T}-H_{290}\right) / T \\
(\text { e.u. })\end{array}$ & $\begin{array}{l}-\Delta G_{f}^{0} \\
(\mathrm{kcal})\end{array}$ \\
\hline 298 & 16.66 & 0 & 0 & 19.70 & 240.1 \\
\hline 300 & 16.70 & 30 & 0.10 & 19.70 & \\
\hline 400 & 18.21 & 1786 & 5.14 & 20.38 & 235.8 \\
\hline 500 & 19.00 & 3650 & 9.30 & 21.70 & \\
\hline 600 & 19.50 & 5576 & 12.81 & 23.22 & 227.1 \\
\hline 700 & 19.86 & 7545 & 15.84 & 24.76 & \\
\hline 800 & 20.15 & 9546. & 18.52 & 26.28 & 218.6 \\
\hline 900 & 20.40 & 11574 & 20.90 & 27.74 & \\
\hline 1000 & 20.62 & 13625 & 23.06 & 29.14 & 210.0 \\
\hline 1100 & 20.82 & 15697 & 25.04 & 30.47 & \\
\hline 1200 & 21.02 & 17789 & 26.86 & 31.73 & 201.5 \\
\hline 1300 & 21.20 & 19900 & 28.55 & 32.94 & \\
\hline 1400 & 21.38 & 22030 & 30.13 & 34.09 & 193.2 \\
\hline 1500 & 21.56 & 24176 & 31.61 & 35.19 & \\
\hline 1600 & 21.73 & 26341 & 33.00 & 36.24 & 185.0 \\
\hline 1700 & 21.90 & 28522 & 34.33 & 37.25 & \\
\hline 1800 & 22.06 & 30720 & 35.58 & 38.22 & 276.9 \\
\hline 1900 & 22.23 & 32934 & 36.78 & 39.15 & \\
\hline 2000 & 22.39 & 35165 & 37.92 & 40.04 & 168.8 \\
\hline \multicolumn{4}{|c|}{$\begin{array}{l}\Delta G_{\mathrm{f}}^{0}=-252340+42.02 \mathrm{~T} \text { cal } \\
\text { Standard deviation }=334 \mathrm{cal}\end{array}$} & & $\left(298\right.$ to $2000^{\circ} \mathrm{K}$ ) \\
\hline
\end{tabular}

3.5.2. The instability of plutonium monoxide

It is sometimes useful to have an estimate of the instability of the plutonium monoxide phase. It is known $[11,107]$ that the oxygen-rich limit of the $\mathrm{Pu}(\mathrm{O}, \mathrm{C})$ phase is approximately $\mathrm{PuC}_{0.3} \mathrm{O}_{0.7}$ at about $1500^{\circ} \mathrm{K}$. Thus the free energy of the reaction

$$
\langle\mathrm{PuO}\rangle \rightarrow 1 / 3\left\langle\mathrm{Pu}_{2} \mathrm{O}_{3}\right\rangle_{\text {hex }}+1 / 3\{\mathrm{Pu}\}
$$

is negative when $\mathrm{PuO}$ is in its standard state (pure solid), but is approximately zero when the mole fraction of PuO dissolved in "PuC" is about 0.7. Assuming ideal solution behaviour, $\Delta \mathrm{G}^{0}=\mathrm{RT} \cdot \ln 0.7=-1063 \mathrm{cal}$. The monoxide is thus unstable to disproportionation by about a kilocalorie.

\subsection{Tabulation of thermochemical data}

The thermochemical data for the oxides are presented in Table XI together with an equation for the free energy of formation. The more convenient two-term equations are given, since these always fit the data to within their precision. One more significant digit than is warranted by the precision of the data is retained to avoid rounding errors. At temperatures above $1000^{\circ} \mathrm{K}$ the error in the values given may increase, 
since the equations relating $C_{p}$ to temperature, given in Sections II.3.1.2.1 II.3.1.2.4, and ensuring precision in the range $300-1000^{\circ} \mathrm{K}$, were used in calculating $\mathrm{C}_{\mathrm{p}}, \mathrm{H}_{\mathrm{T}}-\mathrm{H}_{298}$ and $\mathrm{S}_{\mathrm{T}}-\mathrm{S}_{298}$ up to a temperature of $2000^{\circ} \mathrm{K}$.

The data in Table $\mathrm{X}$ for condensed plutonium were calculated from the specific heat and transformation data given by Rand [70]; data for oxygen were taken from Stull and Sinke [106].

\section{4. VAPORIZATION BEHAVIOUR}

\subsection{Introduction}

The vaporization behaviour of almost all refractory binary materials is significantly influenced by the composition variable. Wide deviations from ideal stoichiometry are frequently encountered at the temperatures necessary to cause measurable vaporization. These systems are bivariant in the sense of the Phase Rule and the vapour pressures are, therefore, a function of both the temperature and composition variables. The previously published measurements of the vapour pressure of plutonium oxide systems are summarized in Table XII. Inspection of these measurements reveals that in the case of Refs [63] and [109] only, the vapour pressure has been correlated with a condensed phase(s) of known composition. The results of the transpiration measurements described in Refs [109] and [110] were obtained in three different atmospheres. In general appearance the values obtained in oxygen are lowest, and those in air and argon are somewhat higher. However, the pronounced lack of precision of the data as indicated by the large random errors associated with the least-squares equations in Table XII, and also the relatively small temperature dependence of the pressure, severely limits the credibility of the accuracy of the se measurements. The agreement among the results (cell No. 1) of Mulford and Lamar [62] and Ackermann et al. [63] obtained with tungsten effusion cells is within a factor of 1.5 and, in the case of tantalum cells, the results of Ackermann et al. [63] are virtually identical with the much earlier measurements of Phipps et al. [108]. The vapour pressures obtained with tantalum cells, corresponding to a greater degree of reduction of the dioxide phase, are approximately a factor of ten greater than those corresponding to the less reducing tungsten cells. Ackermann et al. [63] have accounted for this increase in vapour pressure, and have described thermodynamically the vaporization behaviour of the bivariant $\mathrm{PuO}_{2-x}$ phase $(\sim 1.6<2-x<2.00)$ based on their effusion data given in Table XII and the thermodynamic data for the solid phase(s) reported by Markin and Rand [66]. We shall be concerned primarily with the published results of Ackermann et al. [63] and with the data of Pascard [21] and Ohse [22] submitted to this Panel since they represent the most successful attempts at the present time in correlating the pressure and composition variables.

\subsection{Résumé of experimental data and thermodynamic analysis}

The pattern of vaporization behaviour for the $\mathrm{PuO}_{2-x}$ phase $(\sim 1.6<\mathrm{O} / \mathrm{Pu}<2.0)$ observed by Ackermann et al. [63] for tungsten, 
TABLE XII. VAPOUR PRESSURES OF PLUTONIUM OXIDES

\begin{tabular}{|c|c|c|c|c|c|}
\hline \multirow{2}{*}{$\begin{array}{c}\text { Solid } \\
\text { phase(s) }\end{array}$} & \multicolumn{2}{|c|}{$\log P_{e}(a t m)=A+B / T$} & \multirow{2}{*}{$\begin{array}{l}\text { Temperature } \\
\text { range }\left({ }^{\circ} \mathrm{K}\right)\end{array}$} & \multirow{2}{*}{ Method of measurement } & \multirow{2}{*}{ Reference } \\
\hline & A & B & & & \\
\hline$\left(\mathrm{PuO}_{\sim 1.6}, \mathrm{Pu}_{2} \mathrm{O}_{3}\right)$ & $8.13^{b}$ & -27910 & $1790-2075$ & Ta-effusion cell & [108] \\
\hline$(\mathrm{PuO} \underset{\sim 1.87}{ })$ & $7.82 \pm 0.23$ & $-29700 \pm 500$ & $1990-2380$ & W-effusion cell (No. 1 ) & [62] \\
\hline $\mathrm{PuO}_{2}$ & $3.70 \pm 1.64$ & $-23300 \pm 3100$ & $1770-2060$ & Transpiration-1 atm $\mathrm{O}_{2}$ & {$[109,110]$} \\
\hline $\mathrm{PuO}_{-2}$ & $-0.13 \pm 1.42$ & $-15000 \pm 2700$ & $1730-2060$ & Transpiration- 1 atm air & {$[109,110]$} \\
\hline$\left(\mathrm{PuO}_{2-\mathrm{x}}\right)$ & $-1.91 \pm 1.00$ & $-11800 \pm 1900$ & $1730-2060$ & Transpiration -1 atm argon & {$[109,110]$} \\
\hline $\mathrm{PuO}_{1.92} \pm 0.01$ & $7.50 \pm 0.15$ & $-29260 \pm 280$ & $1640-2070$ & $\mathrm{~W}$-and $\mathrm{R}$-effusion cells & {$[63]$} \\
\hline $\mathrm{PuO}_{\sim_{1.6}}, \mathrm{Pu}_{2} \mathrm{O}_{3}$ & $8.09 \pm 0.27^{b}$ & $-27800 \pm 500$ & $1645-2105$ & Ta-effusion cell & [63] \\
\hline
\end{tabular}

${ }^{\mathrm{a}}$ The parentheses indicate uncertainty in the identification and composition of the solid phase(s).

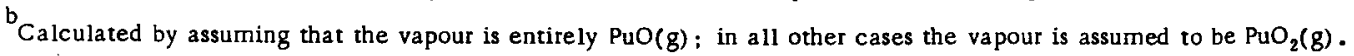




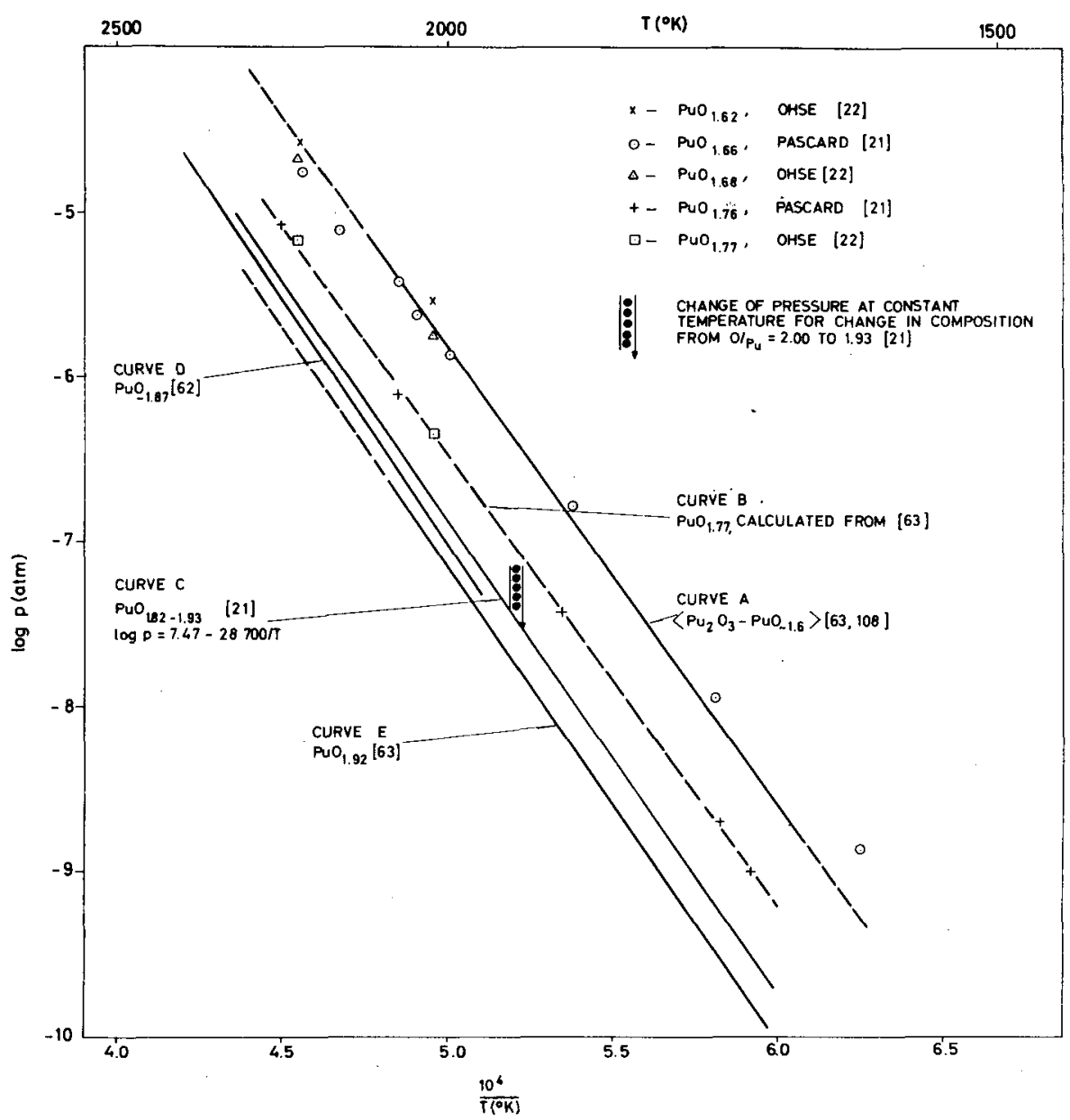

FIG. 7. Vapour pressure of plutonium-bearing species versus composition and temperature for substoichiometric plutonium oxides.

rhenium and tantalum effusion cells, and by Pascard [21] and Ohse [22] for tungsten cells, demonstrates two important aspects; the pressurecomposition bivariancy of the dioxide phase and the existence of at least two principal modes of vaporization involving plutonium-bearing species. The effusion rates were measured by the radiochemical analysis of collections corrected for americium content and correspond to systems whose compositions were obtained from chemical and X-ray analysis before and after the measurements. The combined results of the three investigations are shown in Fig. 7. Curve A represents the nearly identical results of Phipps et al. [108] and Ackermann et al. [63] obtained from tantalum effusion cells and given by Eqs 1 and 7 in Table XII. Curve $B$ represents the dependence of $\log \mathrm{p}$ versus $1 / \mathrm{T}$ for $\mathrm{O} / \mathrm{Pu}=1.77$ calculated from the thermodynamic data given by Ackermann et al. [63] . Curve $C$ represents a composite least-squares treatment of various 
sets of experimental data corresponding to the compositions, $\mathrm{O} / \mathrm{Pu}=1.82$, 1.85 and 1.93 . Within the precision of the data the measured pressures appear to be insensitive to the composition variable and, therefore, are represented by a single curve. Curve D gives the plot of Eq. 2 in Table XII obtained by Mulford and Lamar [62] for their principal set of data (tungsten cell No.1). The composition of $\mathrm{PuO}_{1.87}$ has been assigned via the value of the lattice parameter of the quenched residue, $5.44 \AA$, and the results of Gardner et al. [13] extrapolated to room temperature. Curve E represents the data of Ackermann et al. [63] given by Eq. 6 in Table XII and corresponding to the composition $\mathrm{PuO}_{1.92}$. Ackermann et al. [63], Pascard [21] and Ohse [22,111] have observed a gradual decrease in the pressure of plutonium-bearing species at constant temperature during the incongruent vaporization of initially $\mathrm{PuO}_{2.00^{\circ}}$ In the former case the extent of decrease was approximately $30 \%$, whereas in the latter case the decrease was a factor of three as shown by the vertically arrayed solid points in Fig. 7.

The examination by $\mathrm{X}$-ray diffraction of the vaporization residues, having compositions between $\mathrm{O} / \mathrm{Pu}=1.66-1.93$ in the investigations by Ackermann et al. [63], Pascard [21] and Ohse [22] invariably indicated the presence of the two phases $\mathrm{PuO}_{1.98}$ (face-centred cubic) and $\mathrm{PuO}_{1.52}$ (body-centred cubic) in varying proportions. Quite clearly both phases could not have been present at the temperatures of the effusion measurements since their presence would have defined a univariant system, so that constant rather than varying effusion rates would have been observed. This evidence suggests the disproportionation of the $\mathrm{PuO}_{2-\mathrm{x}}$ phase upon cooling, and confirms the findings of many previous investigators [66]. Only Mulford and Lamar [62] have succeeded in quenching the $\mathrm{PuO}_{2-\mathrm{x}}$ phase to room temperature and this singular success is believed to have resulted from the stabilization of the phase by a small tungsten impurity.

Apart from minor discrepancies, as indicated by curves $C, D$, and $E$, the data in Fig. 7 clearly show that the effect of changing composition on the total pressure of plutonium-bearing species is relatively small for compositions in the range $\mathrm{O} / \mathrm{Pu}-1.93-1.82$, but becomes more important at lower compositions. This behaviour and the decrease in the pressure observed from initially stoichiometric oxide demonstrate the existence of a congruently vaporizing composition in the $\mathrm{PuO}_{2+x}$ phase region. When the condensed phase contains more oxygen than this, the vapour is richer in oxygen than the solid, which is thus chemically reduced; conversely, when the condensed phase contains less oxygen than the congruently vaporizing composition, it is oxidized by loss of a vapour richer in plutonium. In both cases, the total effusion rate decreases and the composition of the solid moves towards the congruently vaporizing composition. Ohse [111] has observed this decrease in the pressure of plutonium-bearing species at $2000^{\circ} \mathrm{K}$ from both sides of the hightemperature single-phase region starting at $\mathrm{O} / \mathrm{Pu}=1.62$ and 2.00 towards a minimum at the congruently vaporizing composition near 1.85 . An extrapolation of the vapour pressure towards $\mathrm{PuO}_{2.00}$ confirms the results of Pascard [21].

The existence of a congruently vaporizing composition requires at least two modes of vaporization. The atomic and molecular vapour 
TABLE XIII. STANDARD FREE ENERGIES OF FORMA TION

\begin{tabular}{l|c|c|c|c}
\hline \multirow{2}{*}{ Species } & \multicolumn{2}{|c|}{$\Delta G_{\mathrm{f}}^{0}=\Delta \mathrm{H}_{\mathrm{f}}^{0}-\mathrm{T} \Delta \mathrm{S}_{\mathrm{f}}^{0}$} & & \\
\cline { 2 - 3 } & $\Delta \mathrm{H}_{\mathrm{f}}^{0}(\mathrm{ca1} / \mathrm{mole})$ & $\Delta \mathrm{S}_{\mathrm{f}}^{0}(\mathrm{e} . \mathrm{u})$. & & \\
\hline & 80500 & 23.0 & $1500-2500$ & {$[112]$} \\
$\mathrm{Pu}(\mathrm{g})$ & -29000 & 12.1 & $1600-2150$ & {$[63]$} \\
$\mathrm{PuO}(\mathrm{g})$ & -113100 & -4.35 & $1600-2150$ & {$[63]$} \\
$\mathrm{PuO}_{2}(\mathrm{~g})$ & 61250 & 16.07 & $1500-2500$ & {$[106]$} \\
$\mathrm{O}_{(\mathrm{g})}$ & -249500 & 40.3 & $1600-2150$ & {$[63]$} \\
$\mathrm{PuO}_{2}$ (s) & & & & \\
\hline
\end{tabular}

a This equation is derived for the relatively short temperature range indicated, and yields values of $\Delta G_{\mathrm{f}}^{0}$ that are virtually identical with those given in Table XI.

species in equilibrium with the solid plutonium oxides have not been directly observed in any of the previous measurements. They can be deduced, however, with reasonable certainty from the following consideration [63]. On the basis of the measurements of the partial molar free energy of oxygen for the $\mathrm{PuO}_{2-x}$ phase [66], the vapour pressure of liquid plutonium [112], the previous studies of the vaporization behaviour of the thorium-[113], uranium-[114-116] and neptunium-oxygen [117] systems, and the trends in chemical bonding observed in actinidemetal oxides [118], it is concluded that both atomic and molecular oxygen are overwhelmingly predominant near the stoichiometric composition and that the principal plutonium-containing species is $\mathrm{PuO}_{2}(\mathrm{~g})$. At the lower phase boundary $\mathrm{PuO}(\mathrm{g})$ is predominant and the principal mode of vaporization that occurs is

$$
\frac{0.61}{0.22}\left\langle\mathrm{Pu}_{2} \mathrm{O}_{3}\right\rangle_{\text {hex }}=(\mathrm{PuO})+\frac{0.50}{0.11}\left\langle\mathrm{PuO}_{1.61}\right\rangle
$$

From the known free energies of formation of the two solid phases $[63,70]$ and the vapour pressure given by Eq. 7 in Table XII, the standard free energy of formation of $\mathrm{PuO}(\mathrm{g})$ is calculated and given in Table XIII. The known contribution of $\mathrm{PuO}(\mathrm{g})$ to the measured vapour pressures of $\mathrm{PuO}_{1.92}$ (Eq. 6 in Table XII) via the mode of vaporization,

$$
\left\langle\mathrm{PuO}_{1.92}\right\rangle \rightarrow(\mathrm{PuO})+0.92(0)
$$




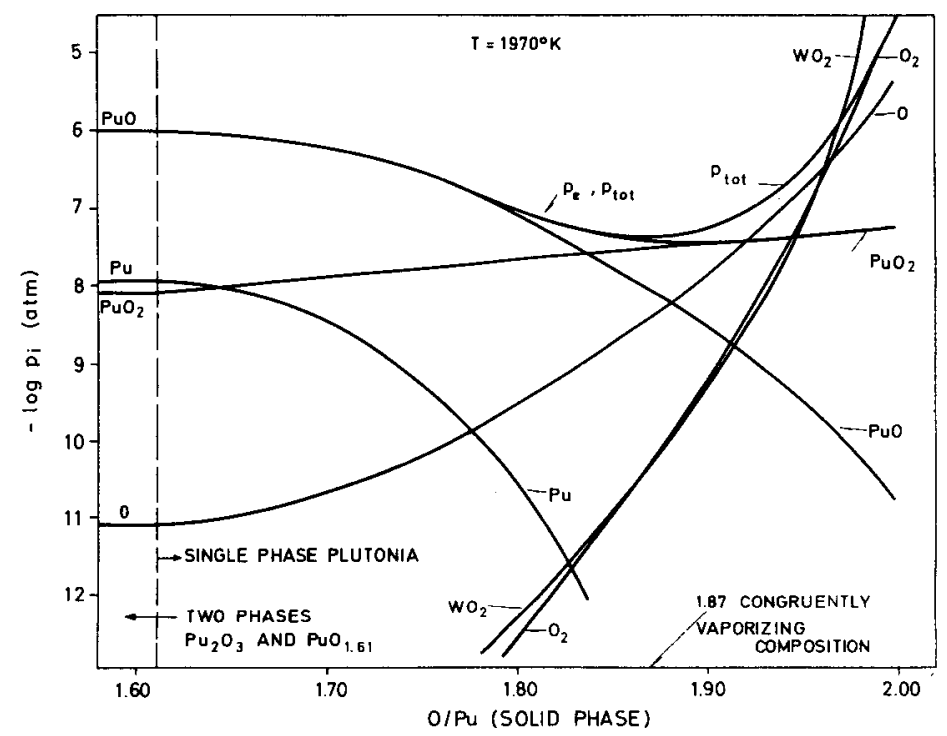

EIG. 8. Partial pressures of vapour species versus composition of substoichiometric plutonium dioxide at $1970^{\circ} \mathrm{K}$. (Courtesy of the Journal of Physical Chemistry [63].)

can be calculated from the thermodynamic quantities cited above and subtracted from the measured vapour pressure to yield the partial pressure of $\mathrm{PuO}_{2}(\mathrm{~g})$ via the mode of vaporization,

$$
\left\langle\mathrm{PuO}_{1.92}\right\rangle+0.08(0) \longrightarrow\left(\mathrm{PuO}_{2}\right)
$$

from which the standard free energy of formation of $\mathrm{PuO}_{2}(\mathrm{~g})$ given in Table XIII is obtained.

This thermodynamic analysis was carried out using the data from Markin and Rand [66], with slightly different values for the free energies of formation of $\left\langle\mathrm{Pu}_{2} \mathrm{O}_{\mathrm{x}}\right\rangle_{\text {hex }}$ and $\left\langle\mathrm{PuO}_{1.61}\right\rangle$ from those given in Table XI. The differences, however, are quite trivial (less than 100 cal, except at $2000^{\circ} \mathrm{K}$ for $\Delta \mathrm{G}_{\mathrm{f}}^{0} \frac{1}{2}\left\langle\mathrm{Pu}_{2} \mathrm{O}_{3}\right\rangle$ where the difference is $300 \mathrm{cal}$ ) and well within experimental error.

There is a small uncertainty in this thermodynamic analysis arising from the lack of knowledge concerning the composition of the $\left\langle\mathrm{PuO}_{1.61}\right\rangle$ phase at high temperatures. Preliminary experiments by Pascard [21] suggest that the lower boundary of this phase may shift to $\sim \mathrm{PuO}_{1.55}$ above $2000^{\circ} \mathrm{K}$, which would change $\Delta \mathrm{G}_{\mathrm{f}}^{0}$ of $\mathrm{PuO}(\mathrm{g})$ by 1 to $2 \mathrm{kcal}$ [63] .

The detailed vaporization behaviour of the $\mathrm{PuO}_{2-x}$ phase at a temperature of $1970^{\circ} \mathrm{K}$ is summarized in Fig. 8 in which the partial pressures of the various vapour species are given as a function of the composition of the solid phase. This isotherm is typical of many which can be calculated from the thermodynamic data given in [63]. The quantity $p_{\text {tot }}$ includes the partial pressure of oxygen as well as those of plutonium-bearing species. Quite clearly the partial pressures of 
TABLE XIV. CALCULA TED CONGRUENTLY VAPORIZING COMPOSITION OF THE $\mathrm{PuO}_{2 \cdot \mathrm{x}}$ PHASE AS A FUNCTION OF TEMPERA TURE

\begin{tabular}{cc}
\hline$\left.{ }^{\circ} \mathrm{K}\right)$ & $\mathrm{O} / \mathrm{Pu}$ \\
$\because \cdots$ & 1.92 \\
1600 & 1.89 \\
1800 & 1.86 \\
2000 & 1.85 \\
2200 & 1.84 \\
2400 & \\
\hline
\end{tabular}

$\mathrm{PuO}(\mathrm{g}), \mathrm{Pu}(\mathrm{g}), \mathrm{O}(\mathrm{g})$ and $\mathrm{O}_{2}(\mathrm{~g})$ depend markedly on the composition variable in sharp contrast to the rather insensitive dependence of the partial pressure of $\mathrm{PuO}_{2}(\mathrm{~g})$. The values of the pressure of plutoniumbearing species at $1970^{\circ} \mathrm{K}$ given in Fig. 7 agree within a factor of two with the calculated values in Fig. 8 over the entire range of composition. The minimum total pressure in the system occurs for the congruently vaporizing composition $\mathrm{O} / \mathrm{Pu}=1.87$. The relatively insensitive dependence of the pressure $p_{e}$ on the composition is immediately recognized. The dependence of the congruently vaporizing composition on temperature has been calculated [63] and is shown in Table XIV. At present, one value at $2000^{\circ} \mathrm{K}$ has been confirmed experimentally by Ohse [111] by extrapolating both parts of the isotherm.

The agreement of the various sets of data within a consistent thermodynamic framework is generally encouraging. The nearly identical agreement shown by Curve B in Fig. 7 between the pressures measured by Pascard [21] and Ohse [22] for the composition $\mathrm{PuO}_{1.76}$ and $\mathrm{PuO}_{1.77}$ respectively, and that calculated for the composition $\mathrm{PuO}_{1.77}$ from the thermodynamic data of Ackermann et al. [63], is certainly noteworthy.

However, there is evidence in Curve $A$ of a small discrepancy between the least-squares results of the univariant system $\mathrm{Pu}_{2} \mathrm{O}_{3}-\mathrm{PuO}_{1,61}$ vapour, and the data of Pascard [21]. Since in the former system the measured pressure corresponds to the lower phase boundary of the plutonia phase, the values obtained for more oxidized compositions cannot, in principle, be larger. It should be noted also that the thermodynamic description of the plutonia phase does not account for the decrease of a factor of three in the total plutonium pressure in the composition range between the stoichiometric and congruently vaporizing compositions observed by Pascard [21] but rather predicts a decrease of approximately $30 \%$ only. In fact the large decrease observed by Pascard may indicate the existence of another vapour species (at the quite large pressures 
of oxygen near the stoichiometric composition), which may be $\mathrm{PuO}_{3}(\mathrm{~g})$, or perhaps a ternary species involving tungsten, plutonium and oxygen.

It is difficult to accommodate the transpiration measurements of

Pardue and Keller [109] within the framework of the analysis of the effusion studies. The vapour pressures measured under one atmosphere of oxygen, which corresponds to the stoichiometric dioxide, are inconsistent with the present analysis and are nearly an order of magnitude smaller than those calculated by means of the equations given in Table XIII for the process $\mathrm{PuO}_{2}(\mathrm{~s}) \rightarrow \mathrm{PuO}_{2}(\mathrm{~g})$. An apparent increase in vapour pressure was observed when the transpiring gas was changed to air and argon. This increase is attributed to the vaporization of $\mathrm{PuO}(\mathrm{g})$. It is possible, of course, to reduce $\mathrm{PuO}_{2}(\mathrm{~s})$ beyond the congruently vaporizing composition in an inert atmosphere such as argon to an extent limited by the value of the partial pressure of oxygen in the argon, and thereby increase the total vapour pressure through the vaporization of $\mathrm{PuO}(\mathrm{g})$. But it is difficult to see how this species can make a significant contribution to the vapour pressure via the process $\left\langle\mathrm{PuO}_{2}\right\rangle \longrightarrow \mathrm{PuO}(\mathrm{g})+\mathrm{O}(\mathrm{g})$ when the oxygen pressure is reduced from one atm to $0.2 \mathrm{~atm}$; both of these high oxygen pressures will overwhelmingly suppress the evaporation of $\mathrm{PuO}(\mathrm{g})$.

\subsection{Intercomparison of the plutonium- and uranium-oxygen systems}

In the intercomparison of the vaporization behaviour of the plutonium and uranium oxides there exists a broad spectrum of similar as well as dissimilar aspects. The vapour pressures of both dioxides for the stoichiometric as well as the congruently vaporizing compositions are nearly equal with respect to the gaseous dioxide, which is the predominant metal-bearing species. It is the relatively insensitive dependence of the gaseous dioxide on the composition of the solid phase that allows the less rigorous identification of its partial pressure with a precisely known composition as has been described in Ref. [117] .

In the case of plutonium dioxide, however, the preferential loss of atomic and molecular oxygen (see Fig. 8) is considerably greater than for uranium dioxide, and hence the congruently vaporizing composition of uranium dioxide is much nearer the stoichiometric value. It is the relatively large partial pressure of oxygen that explains the observed reaction between plutonium dioxide and the refractory metals tungsten and rhenium $[63,111]$.

At the lower phase boundary of the $\mathrm{MO}_{2-\mathrm{x}}$ phase the gaseous monoxide is the major vapour component in both the uranium and plutonium systems. Since there is no stable sesquioxide phase in the uranium system, this is also the case at the oxygen-rich boundary of the metal phase; for plutonium, however, the principal species over the $\{\mathrm{Pu}\}+\left\langle\mathrm{Pu}_{2} \mathrm{O}_{3}\right\rangle$ phase region is the gaseous metal and not the monoxide, at least up to $\sim 2750^{\circ} \mathrm{K}$. Whereas uranium dioxide can dissolve oxygen and extend its upper phase boundary to superstoichiometric values thereby causing the predominant vaporization of $\mathrm{UO}_{3}(\mathrm{~g})$ at high temperatures, plutonium dioxide does not show any evidence either for dissolving oxygen [26] or for stable higher solid oxides. 
It is possible to examine the consistency and, to some extent, the reliability of the thermodynamic properties of the gaseous plutonium oxides via the homogeneous equilibrium

$$
(\mathrm{M})+\left(\mathrm{MO}_{2}\right) \rightarrow 2(\mathrm{MO})
$$

From the values given in Table XIII one calculates

$$
\Delta G^{0}(M=P u)=-25400-5.6 T
$$

From the measurements of the equilibrium constant by Ackermann et al. [116] one calculates

$$
\Delta \mathrm{G}^{0}(\mathrm{M}=\mathrm{U})=-9600-5.8 \mathrm{~T}
$$

Quite evidently the equilibrium is displaced to the right for the case of plutonium, which indicates the relatively greater thermodynamic stability of $\mathrm{PuO}(\mathrm{g})$ compared with $\mathrm{UO}(\mathrm{g})$. The consistency between the two systems appears to be borne out by the nearly constant entropy change $\left(\Delta S^{0} \simeq 5.7\right.$ e.u. $)$, which is to be expected for such closely related equilibria.

\section{5. CONCLUSIONS AND FUTURE WORK}

The plutonium oxygen system is known to contain at least four solid phases, some of which have wide homogeneity ranges, and although there is agreement about the general shape of the phase diagram, the finer details are still far from clear. In particular the detailed crystal structure of the $\left\langle\mathrm{PuO}_{1.61}\right\rangle$ phase is not known, nor is the interrelationship of the cubic $\left\langle\mathrm{PuO}_{1.52}\right\rangle$ phase with hexagonal $\left\langle\mathrm{Pu}_{2} \mathrm{O}_{3}\right\rangle$; these uncertainties lead to an uncertainty in the phase diagram.

Body-centred cubic symmetry for the $\mathrm{PuO}_{1.61}$ phase requires the presence of a miscibility gap between it and the substoichiometric fluorite-type $\mathrm{PuO}_{2-\mathrm{x}}$ phase, whereas no such gap is required if $\mathrm{PuO}_{1.61}$ has face-centred cubic symmetry. The existing lattice parameter and oxygen potential measurements, from which the phase diagram is mainly inferred, are consistent with either representation, and impose only a few restrictions on the possible position of the miscibility gap. The area between $1100^{\circ} \mathrm{C}$ and the liquidus has received little study and the liquidus lines themselves are not well defined.

A further high-temperature X-ray study, using well-crystalline samples, is most necessary, but detailed knowledge of the position of the oxygen atoms in $\mathrm{PuO}_{1.61}$ must await a neutron diffraction study of this phase, which will of course necessitate the use of an oxide containing $240 \mathrm{Pu}$ or $242 \mathrm{Pu}$ isotopes rather than ${ }^{239} \mathrm{Pu}$. Useful information on the existence of a miscibility gap in the phase diagram could come from a 
more detailed study of the electrical resistivity of oxides between $\mathrm{Pu}_{2} \mathrm{O}_{3}$ and $\mathrm{PuO}_{2}$, since there is a suggestion that the face-centred cubic oxides are $n$-type semiconductors, whereas the body-centred cubic phase is p-type. A valuable contribution to the phase diagram near $\mathrm{PuO}_{1.61}$ at temperatures between 1200 and $2200^{\circ} \mathrm{C}$ could come from a study of the vaporization behaviour, since there is some evidence that the lower phase boundary of $\mathrm{PuO}_{1.61}$ moves to lower compositions at temperatures around $1600^{\circ} \mathrm{C}$. The lower part of the temperature range would require the use of a $238 \mathrm{Pu}$ doped oxide to obtain sufficient sensitivity.

It must also be remembered that the application of thermobalance techniques to the lanthanide oxide systems has brought out a great deal of the fine structure of these diagrams, and a similar study of the plutonium-oxygen system, though experimentally much more difficult because of the very low oxygen potentials involved, might well be worth undertaking. In addition, such a study might throw some light on the existence of a miscibility gap.

Reliable and accurate heat capacity data for the oxides are lacking, so that absolute values of all the entropies are based on estimates. Some entropy differences, however, are known with fair precision from equilibrium data. However, both low- and high-temperature heat capacity values are likely to be available within the next two years, and it will be interesting to observe whether $\mathrm{PuO}_{2}$ is found to have a magnetic ordering effect similar to that in $\mathrm{UO}_{2}$ and $\mathrm{NpO}_{2}$; there is a little evidence that such an effect is lacking even down to $2^{\circ} \mathrm{K}$.

Magnetic susceptibility measurements of all the oxides down to liquid helium temperatures are urgently required to provide supplementary evidence to elucidate their electronic structure at low temperatures. The success of the attempt to reproduce experimental heat capacities up to room temperature from a relatively simple lattice dynamical calculation derived from the intensities of neutron diffraction reflections for $\mathrm{UO}_{2}$ suggests that a similar calculation should be made for $\mathrm{PuO}_{2}$, particularly in view of the difficulties associated with accurate heat capacity measurements of radioactive materials at low temperatures.

Calorimetric determinations of the heat of formation of hexagonal $\mathrm{Pu}_{2} \mathrm{O}_{3}$ and cubic $\mathrm{PuO}_{1.52}$ are desirable. Since the latter material is difficult to prepare as a pure single phase material, it may be necessary to burn a number of oxides of varying composition between $\mathrm{PuO}_{1.52}$ and $\mathrm{PuO}_{1.98}$, which would consist of these two phases at room temperature. Such a method would provide a bonus in the shape of the heat of formation of the $\left\langle\mathrm{PuO}_{1.98}\right\rangle$ phase.

The oxygen potential measurements at high temperatures agree reasonably well over the temperature range at which they overlap, though the partial molar enthalpies and entropies derived therefrom show a markedly different compositional variation. This may be a real effect, due to different types of defect predominating in the relevant temperature ranges. However, the good agreement of the experimental and calculated vapour pressures for the $\mathrm{PuO}_{2-\mathrm{x}}$ phase suggests that the free energy values obtained by extrapolation of the EMF data cannot be seriously in error. Further equilibrium data at temperatures above $1100^{\circ} \mathrm{C}$ are clearly required; in addition to the $\mathrm{H}_{2} / \mathrm{H}_{2} \mathrm{O}$ reaction already employed, $\mathrm{C}-\mathrm{CO}$ 
equilibrations may be very useful for certain temperature ranges. However, the good agreement of the experimental and calculated vapour pressures for the $\mathrm{PuO}_{2-x}$ phase suggests that the values obtained by extrapolation of the EMF data cannot be seriously in error. Further work by gas equilibration is planned, but the possibility of $\mathrm{C}-\mathrm{CO}$ equilibration should not be overlooked.

It must also be remembered that the use of the Calvet microcalorimeter now makes possible the direct measurement of the partial molar heat of solution of oxygen in non-stoichiometric phases, and such measurements on $\mathrm{PuO}_{2-x}$, particularly near the stoichiometric composition, would provide a rigorous test for the statistical thermodynamical treatment of this defect structure, which is being developed.

The partial molar enthalpies and entropies derived from the EMF work have been integrated to give enthalpy and entropy differences between hexagonal $\mathrm{Pu}_{2} \mathrm{O}_{3}$ and $\mathrm{PuO}_{2}$. Recent work on the cerium oxide heat capacities suggests that the heat capacity values assumed in the original integration may not now be the best values, but since accurate data for the oxides are likely to be available shortly the Panel did not feel justified in attempting the re-integration involved, particularly in view of the uncertainty in the phase diagram. The differences in free energies involved are well within the precision with which the data are known.

There is generally excellent agreement on the vaporization data for the plutonium oxides between five sets of workers, using the effusion technique, and the free energies of formation calculated from the results (and the extrapolated oxygen potential data) can in turn be used to calculate the vapour pressure and composition over any plutonium oxide. The agreement between these calculated and experimental values is most encouraging, and indicates that the free energies of the gaseous species cannot be greatly in error. However, a mass-spectrometric study of the vapour species, particularly near the stoichiometric composition, would be most welcome. In addition, some further experimental verification of the congruently vaporizing composition is required. 


\section{THE URANIUM-PLUTONIUM-OXYGEN SYSTEM}

\section{PREPARATION}

\subsection{Preparation of closely stoichiometric solid solutions with 0 to $30 \% \mathrm{Pu}$}

Homogeneous solid solutions can be prepared by sintering various co-precipitated materials. Mechanical mixtures of fine grained powders of $\mathrm{UO}_{2}$ and $\mathrm{PuO}_{2}$ can be used if prolonged heat treatment at 1500 to $1600^{\circ} \mathrm{C}$ is used. The degree of homogeneity can be estimated in this case from the line profiles of diffractometer traces, preferably using monochromatic $X$-rays [119] .

In the range from pure $\mathrm{UO}_{2}$ up to $30 \% \mathrm{PuO}_{2}$, the sintering conditions required to produce near stoichiometric solid solutions are not critical. It is sufficient to sinter in an atmosphere of wet hydrogen with 1 to $10 \%$ water or wet hydrogen-inert gas mixtures at temperatures around $1500^{\circ} \mathrm{C}$. Non-stoichiometric compositions may be brought to stoichiometry by equilibrating the specimen with a gas mixture of $\mathrm{CO} / \mathrm{CO}_{2} \approx 10$ at $700-850^{\circ} \mathrm{C}$ or again wet hydrogen. The ease of obtaining the stoichiometric composition is due to the fact that the oxygen potential changes by many orders of magnitude over a very narrow range of composition near $\mathrm{MO}_{2.00}$ (see Section III. 3). The oxygen partial pressures for this near-stoichiometric region have been collected in Fig. 9 .

The thermochemical behaviour for oxides containing more than $30 \%$ $\mathrm{Pu}$ has not yet been studied. Studies in the U-Ce-O system in the high cerium region show that one should be cautious in extrapolating the results at $30 \% \mathrm{Pu}$ to higher plutonium contents in the U-Pu-O system [120] (see Section III. 3).

\subsection{Preparation of other compositions}

Superstoichiometric and substoichiometric mixed oxides of any plutonium content may be prepared from the near stoichiometric composition $\mathrm{MO}_{2}$ by equilibration with a gas or gas mixture of determined oxygen partial pressure between 750 and $1600^{\circ} \mathrm{C}$. Convenient gases are carefully dried hydrogen at $1600^{\circ} \mathrm{C}$ for very reduced oxides, $\mathrm{H}_{2} \mathrm{O} / \mathrm{H}_{2}$ or $\mathrm{CO}_{2} / \mathrm{CO}$ mixtures for slightly oxidized compositions, and air or pure oxygen at $750^{\circ} \mathrm{C}$ for complete oxidation.

Another way of preparing mixed oxides of any desired $\mathrm{Pu} /(\mathrm{U}+\mathrm{Pu})-$ and $\mathrm{O} / \mathrm{M}$-ratio is the reaction sintering of mechanically mixed powders. In the case of mixtures of $\mathrm{PuO}_{2}$ or $\mathrm{MO}_{2}$ with carbon, the blended powder compacts are sintered at 1500 to $1600^{\circ} \mathrm{C}$ under a vacuum of $3 \times 10^{-6}$ to $1 \times 10^{-5}$ Torr. The $\mathrm{CO}$ gas evolved during the reaction is pumped off. The reaction products have densities of about $95 \%$ for $\mathrm{Pu}$ contents in the vicinity of $20 \%$. For compositions higher in Pu the density is lower. 
The desired $\mathrm{O} / \mathrm{M}$ ratio can be adjusted by varying the amount of carbon used [121]. In this way the limiting oxygen deficient $\mathrm{O} / \mathrm{M}$ ratio can be produced corresponding to the equilibrium of the mixed oxide with the carbon stabilized monoxide $\mathrm{M}(\mathrm{O}, \mathrm{C})$. The other method of reaching the lower limit in the $\mathrm{O} / \mathrm{M}$ ratio is reaction sintering of a powder compact of $\mathrm{MO}_{2}$ and the corresponding alloy, or $\mathrm{U}+\mathrm{PuO}_{2}$ or $\mathrm{UO}_{2}+\mathrm{Pu}$ with an excess of metal under hydrogen [9].

Mixed oxides with a desired plutonium content not too far from stoichiometric $\mathrm{MO}_{2}$ can be produced by blending the appropriate amounts of $\mathrm{U}_{3} \mathrm{O}_{8}$ and $\mathrm{PuO}_{2}$, and sintering under inert gas/wet hydrogen mixtures at about $1600^{\circ} \mathrm{C}[9]$.

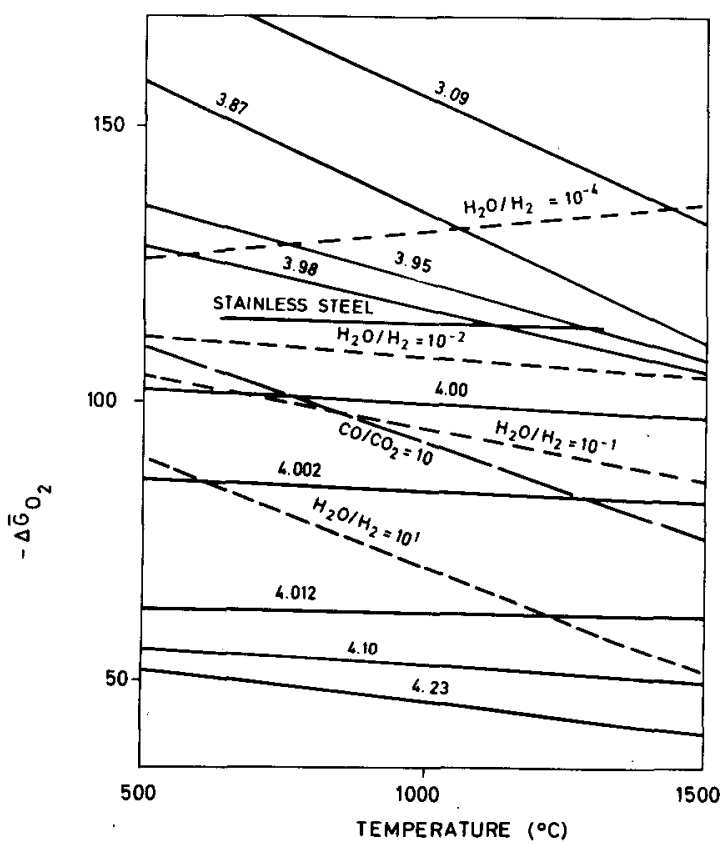

FIG.9. $\Delta \bar{G}_{\mathrm{O}_{2}}$ for (U,Pu) $\mathrm{O}_{2 \pm \mathrm{X}}$ solid solutions for various values of $\mathrm{U}$ and $\mathrm{Pu}$ valence. Oxygen potentials of $\mathrm{H}_{2} \mathrm{O} / \mathrm{H}_{2}$ and $\mathrm{CO} / \mathrm{CO}_{2}$ mixtures and stainless steel are included.

\subsection{Analysis}

The $\mathrm{U} / \mathrm{Pu}$ ratio in the mixed oxides is usually taken to be that in the initial mixture; analytical checks, in which the uranium content is measured by fluorescence and the plutonium usually by alpha counting, have shown that this assumption is justified for homogeneous materials for the normal method of preparation.

$\mathrm{O} / \mathrm{M}$ ratios are obtained by bringing the sample back to the stoichiometric $\mathrm{MO}_{2.00}$ compositions by equilibration in $\mathrm{CO} / \mathrm{CO}_{2}$ mixtures as discussed above, with measurement of the weight change or the volume of oxygen taken up by or removed from the gas phase. 


\section{PHASE DIAGRAM}

\subsection{Below $1400^{\circ} \mathrm{C}$}

\subsubsection{General}

The details of the U-Pu-O phase diagram up to $1000^{\circ} \mathrm{C}$ have been obtained mainly by lattice parameter measurements, both at temperature (up to $1000^{\circ} \mathrm{C}$ ) and on quenched samples; metallographic examination has provided useful information on samples quenched from rather higher temperatures.

In the following sections percentages of plutonium refer to the percentage of the cations, i.e. $100 \times \mathrm{Pu} /(\mathrm{U}+\mathrm{Pu})$.

\subsubsection{Stoichiometric compositions}

It is now well established that the mixed (U, $\mathrm{Pu}$ ) oxides with the stoichiometric composition form a continuous solid solution from $\mathrm{UO}_{2}$ to $\mathrm{PuO}_{2}$, and the lattice parameters of the stoichiometric composition obey Végard's Law as long as the stoichiometry is carefully controlled [122-125].

\subsubsection{Oxidation to $\mathrm{MO}_{2+x}$}

Oxidation in air at $750-1000^{\circ} \mathrm{C}$ of $(\mathrm{U}, \mathrm{Pu})$ oxides results in the formation of cubic and/or orthorhombic phases when the oxide is allowed to cool to room temperature $[9,123,124]$. Oxides containing more than $39 \% \mathrm{Pu}$ can be oxidized until the valency of all the uranium has changed from 4 to 5 , and a single face-centred cubic phase results. The lattice parameter versus $\mathrm{Pu}$ concentration plot for more than $39 \% \mathrm{Pu}$ is consistent with oxidation of uranium to $U(V)$. For a $1: 1$ ratio of $(U, P u)$, when all the $\mathrm{U}$ is $\mathrm{U}(\mathrm{V})$, the over-all composition is $\mathrm{M}_{4} \mathrm{O}_{9}$. Oxides containing between 5 and at least $30.7 \% \mathrm{Pu}$ undergo a disproportionation reaction when oxidized in air to form an orthorhombic phase, rich in uranium, and a face-centred cubic phase, rich in plutonium. Oxides containing less than $5 \%$ Pu oxidize in air to a single orthorhombic phase.

Oxidation of samples containing $10 \% \mathrm{Pu}$ at $750-800^{\circ} \mathrm{C}$ to compositions between $\mathrm{MO}_{2.05}$ and $\mathrm{MO}_{2.20}$ results in two cubic phases, one $\mathrm{MO}_{2+x}$ and the other an $\mathrm{M}_{4} \mathrm{O}_{9}$-type phase [126], whereas partial oxidation of material containing $11 \% \mathrm{Pu}$ gives a single face-centred cubic phase up to $\mathrm{MO}_{2.11}$, and two phases, $\mathrm{MO}_{2.11}$ plus $\mathrm{M}_{4} \mathrm{O}_{9}$ at higher $\mathrm{O} / \mathrm{M}$ ratios [127]. The room temperature phase-boundary at $\mathrm{MO}_{2.11}$ moves to higher $\mathrm{O} / \mathrm{M}$ ratios as the temperature is increased. Oxidation of samples with $11 \% \mathrm{Pu}$ beyond $\mathrm{M}_{4} \mathrm{O}_{9}$ results in an orthorhombic $\mathrm{M}_{3} \mathrm{O}_{8-\mathrm{y}}$ phase in equilibrium with $\mathrm{M}_{4} \mathrm{O}_{9}$. Lattice parameter measurements indicate no appreciable range of homogeneity for the $\mathrm{M}_{4} \mathrm{O}_{9}$ phase between room temperature and $800^{\circ} \mathrm{C}$ when the $\mathrm{Pu}$ concentration is $11 \%$. The $\mathrm{O} / \mathrm{M}$ ratio of the face-centred cubic phase in equilibrium with the $\mathrm{M}_{4} \mathrm{O}_{9}$ phase for oxides with $15 \% \mathrm{Pu}$ is 2.19 , virtually independent of temperature up to $800^{\circ} \mathrm{C}$; a small range 


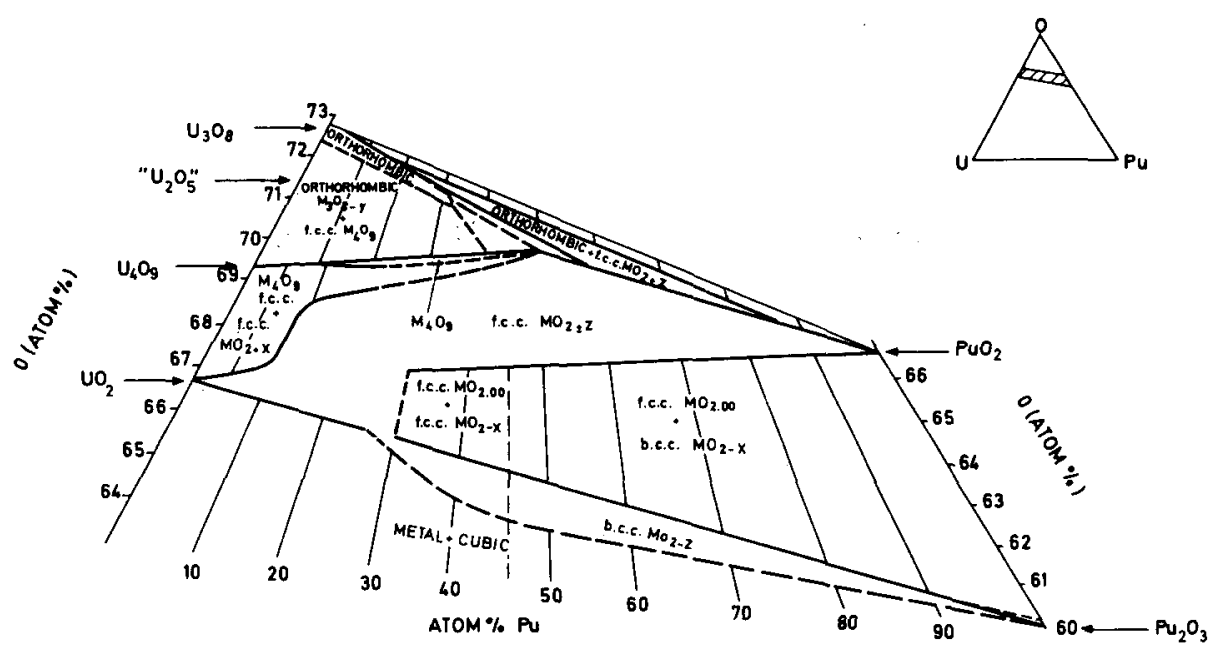

FIG. 10. U-Pu-O ternary section at $20^{\circ} \mathrm{C}$.

of homogeneity, increasing slightly with temperature, has been observed for the $\mathrm{M}_{4} \mathrm{O}_{9}$ phase at this $\mathrm{Pu}$ concentration; further partial oxidation results in two phases, $\mathrm{M}_{4} \mathrm{O}_{9}$ plus $\mathrm{M}_{3} \mathrm{O}_{8-y}[127]$. For oxides containing $30 \% \mathrm{Pu}, \mathrm{M}_{3} \mathrm{O}_{8-y}$ is in equilibrium with $\mathrm{MO}_{2+\mathrm{x}}$ (or $\mathrm{M}_{4} \mathrm{O}_{9}$ ) for oxides of composition $\mathrm{MO}_{2.30}$ (at most) and above.

Oxides containing 15,20 and $35 \% \mathrm{Pu}$ have been oxidized to various $\mathrm{O} / \mathrm{M}$ ratios at $600^{\circ} \mathrm{C}$ and quenched to $20^{\circ} \mathrm{C}[23,119]$. They are twophase, face-centred cubic + tetragonal, for $2,00<\mathrm{O} / \mathrm{M} \leq 2.2$ and two-phase, tetragonal + orthorhombic for $\mathrm{O} / \mathrm{M} \geq 2.39$. The highest $\mathrm{O} / \mathrm{M}$ ratios obtained so far are 2.64 with $15 \% \mathrm{Pu}$ and 2.58 with $35 \% \mathrm{Pu}$. These two values lie sensibly beyond the line connecting $\mathrm{U}_{2} \mathrm{O}_{8}$ and $\mathrm{PuO}_{2}$ (Fig. 10).

The composition of the tetragonal phase has been determined approximately as $2.28<\mathrm{O} / \mathrm{M} \leq 2.35\left(\sim \mathrm{M}_{3} \mathrm{O}_{7}\right)$ by correlating $\mathrm{X}$-ray line intensities of the two-phase mixtures with the oxygen content of the specimens. The lattice parameters are $\mathrm{a}=5.38_{7}$ and $\mathrm{c}=5.54 \AA$ $(c / a=1.028)$ and do not vary with plutonium content in the range 15 to $35 \%$. Specimens oxidized at 1200 and $1400^{\circ} \mathrm{C}$ and annealed for $3 \mathrm{~h}$ at $600^{\circ} \mathrm{C}$ do not give the tetragonal phase. Thus it is not yet clear whether this phase is stable only below $600^{\circ} \mathrm{C}$ or is a metastable product of low-temperature oxidation of $\mathrm{MO}_{2}$. The $\mathrm{c} /$ a ratio of the ternary phase, which can clearly contain a considerable proportion of plutonium, is close to that of the $\gamma_{1}-\mathrm{UO}_{2.33}$ phase [1], which is not stable above $460^{\circ} \mathrm{C}$.

\subsubsection{Reduction to $\mathrm{MO}_{2 \cdot \mathrm{x}}$}

In this region oxides containing less than $30 \% \mathrm{Pu}$ behave rather differently from those with more than $30 \%$, and it is convenient to treat these regions separately. 


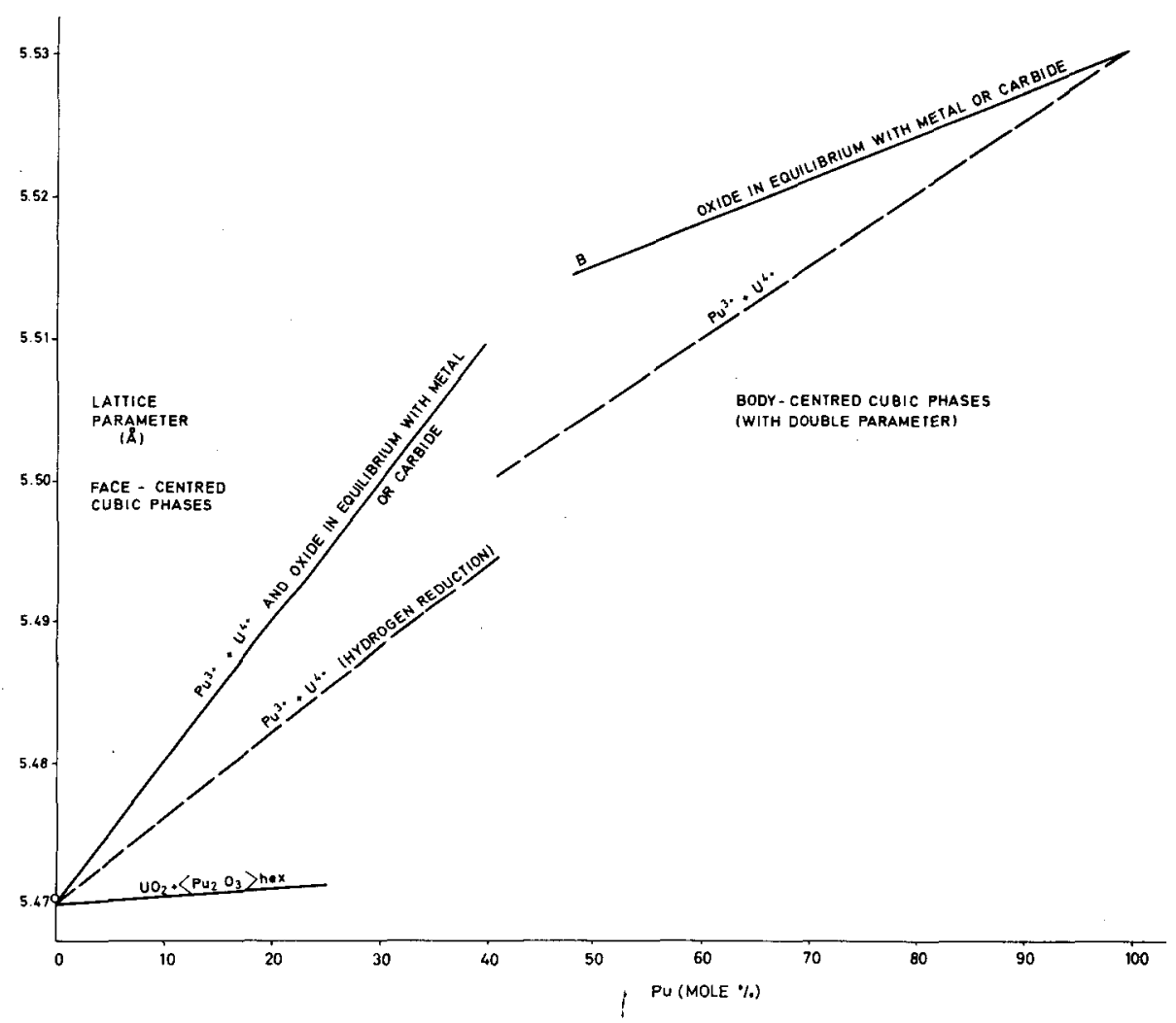

FIG.11. Lattice parameters of "fully-reduced" uranium-plutonium oxides.

2.1.4.1. Below 30\% Pu. For these oxides the single-phase fluorite type $\mathrm{MO}_{2-\mathrm{x}}$ extends down to the alloy in equilibrium with (U, $\mathrm{Pu}$ ) alloy $[9,121]$; at this lower phase boundary all the plutonium is reduced to $\mathrm{Pu}$ (III), but the uranium seems to remain at U(IV). Nevertheless, there are considerable discrepancies in the lattice parameters found for oxides comparing the pseudo-binary $\mathrm{UO}_{2}-\mathrm{PuO}_{1.5}$ oxides in this region. Figure 11 shows that the three methods of preparation (sintering of $\mathrm{UO}_{2}$ with hexagonal $\mathrm{Pu}_{2} \mathrm{O}_{3}[9]$ and reduction of $\mathrm{UO}_{2}-\mathrm{PuO}_{2}$ by dry hydrogen $[23,119,127]$ and by carbon [121] give oxides with very different lattice parameters, although chemical analysis shows they are all on the $\mathrm{UO}_{2}-\mathrm{PuO}_{3.5}$ join. The reason for this behaviour is unknown.

2.1.4.2. Above $30 \% \mathrm{Pu}$. Partial reduction of oxides containing more than $30-40 \% \mathrm{Pu}$ to a substoichiometric composition results in two cubic phases when the oxide is cooled to room temperature; one phase is the $\mathrm{MO}_{2,00}$ phase and the other is the $\mathrm{MO}_{2-x}$ phase in which all the $\mathrm{Pu}$ is trivalent; this phase is face-centred cubic when the Pu concentration is less than $\sim 45 \%$ but body-centred cubic above this. There is no experimental evidence for a miscibility gap between these two structures, although a narrow gap cannot be excluded. At a temperature depending 


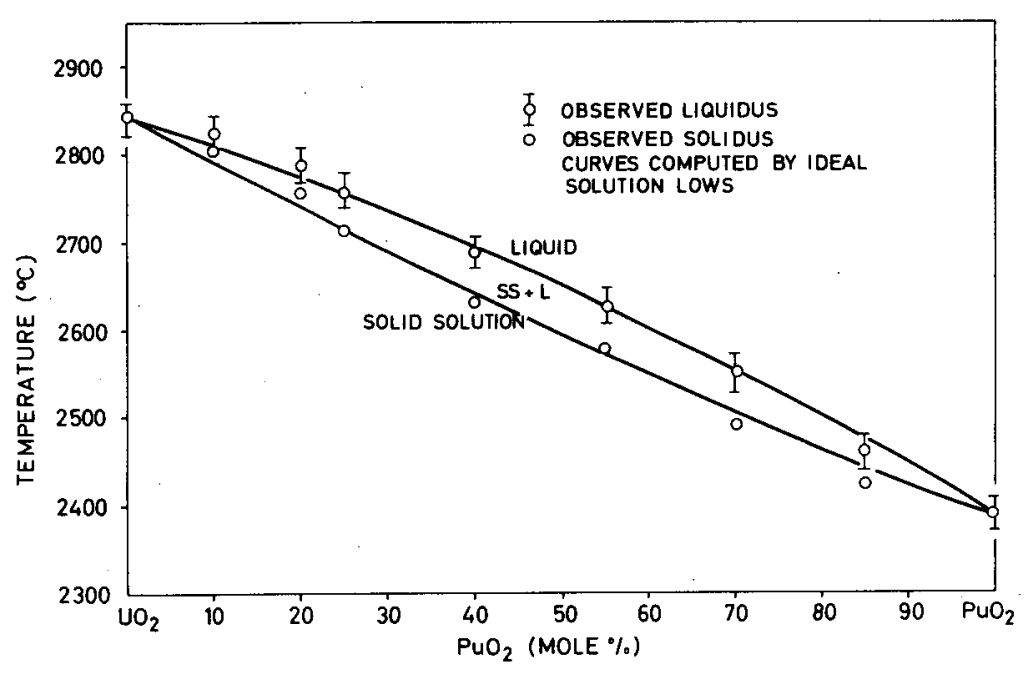

FIG. 12. Solid-liquid phase diagram for the $\mathrm{UO}_{2}-\mathrm{PuO}_{2}$ system.

on the $\mathrm{Pu}$ concentration, the two cubic phases become a single fluoritetype phase. The limiting concentration for two phases to appear at room temperature is not certain; X-ray [127] and metallographic and X-ray [23] results differ for the $30 \% \mathrm{Pu}$ composition.

However, in contrast to the region below $30 \% \mathrm{Pu}$, the phase in equilibrium with ( $\mathrm{U}, \mathrm{Pu}$ ) alloy has a large parameter and presumably less oxygen than the $\mathrm{UO}_{2} \cdot \mathrm{PuO}_{1.5}$ pseudo-binary compositions. The obvious inference is that some reduction of U(IV) to U(III) has occurred. Thus the $\mathrm{MO}_{2-z}$ phase can exist with a range of $\mathrm{O} / \mathrm{M}$ ratios; the composition at the lower phase boundary has not been determined, but extrapolation of line B on Fig. 11 to the uranium axis suggests that the uranium valency may be about 3.8 in the oxides in equilibrium with metal; these thus lie on the $\mathrm{UO}_{1.9} \cdot \mathrm{PuO}_{1.5}$ join.

\subsection{Melting behaviour}

The early determinations [128-130] of melting points in the $\mathrm{UO}_{2} \cdot \mathrm{PuO}_{2}$ system, which indicated a maximum in the liquidus curve near $5-10 \% \mathrm{PuO}_{2}$, were carried out under conditions which must have resulted in some reduction of the plutonium. Recently, however, Lyon and Baily [131] have studied material encapsulated in tungsten. Some slight reduction (to give the equilibrium pressure of gaseous tungsten oxides, see Section II.4) will have occurred at the plutonium-rich end, but the simple liquidus-solidus curve obtained (see Fig. 12) must be closely representative of the stoichiometric system. These curves are consistent with ideal solution theory if the heats of fusion of $\mathrm{UO}_{2}$ and $\mathrm{PuO}_{2}$ are taken to be $21.2 \pm 1.3$ and $16.8 \pm 1.3 \mathrm{kcal} \mathrm{mole}^{-1}$ respectively [132]. 


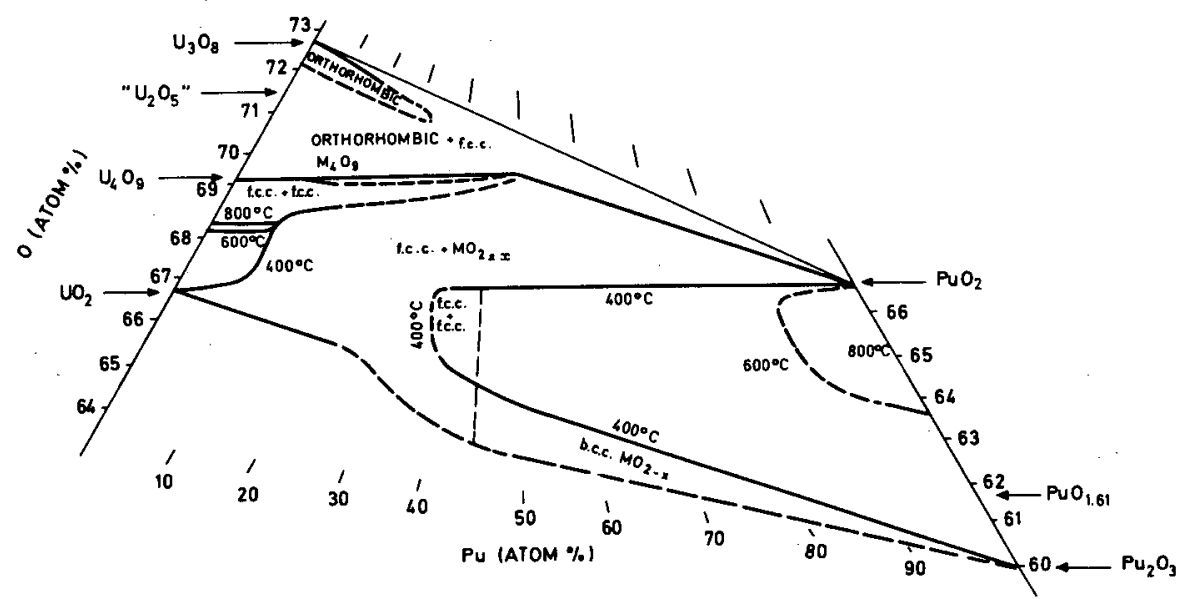

FIG. 13. U-Pu-O temary section at 400,600 and $800^{\circ} \mathrm{C}$.

\subsection{The U-Pu-O phase diagram}

Isothermal sections of the phase diagram at $25,400,600$ and $800^{\circ} \mathrm{C}$ (Figs 10 and 13 ) for the U-Pu-O system have been constructed between the limits $\mathrm{UO}_{1.88}-\mathrm{U}_{3} \mathrm{O}_{8}$ and $\mathrm{PuO}_{2}-\mathrm{PuO}_{1.5}$ for all concentrations of Pu from the results reviewed in the preceding paragraphs and the $\mathrm{U}-\mathrm{O}$ [133] and $\mathrm{Pu}-\mathrm{O}$ (Section II.2) phase diagrams.

The phase boundary for the $\mathrm{MO}_{2-z}$ phase in equilibrium with the metal has been drawn between $\mathrm{PuO}_{1.5}$ and $\mathrm{UO}_{1.88}$ for oxides containing more than $40 \% \mathrm{Pu}$, since extrapolation of the lattice parameter versus $\mathrm{Pu} /(\mathrm{U}+\mathrm{Pu})$ plot for $\mathrm{MO}_{2-\mathrm{z}}$ in equilibrium with $(\mathrm{U}, \mathrm{Pu})$ metal alloy to $\mathrm{Pu}=0$ results in $\mathrm{a}=5.500 \AA$. This lattice parameter corresponds to $\mathrm{UO}_{1.88}$ by analogy with the change in lattice parameter in going from $\mathrm{PuO}_{2}$ to $\mathrm{PuO}_{1.52}$. The phase boundary for oxides in equilibrium with $\left(\mathrm{U}, \mathrm{Pu}\right.$ ) metal alloy has been drawn between $\mathrm{UO}_{2}$ and $\mathrm{PuO}$ for oxides containing less than $30 \% \mathrm{Pu}$.

The lower phase boundary of the orthorhombic plus $\mathrm{MO}_{2+\mathrm{x}}$ twophase region above $\sim 45 \% \mathrm{Pu}$ must lie slightly above the $\mathrm{PuO}_{2} . \mathrm{UO}_{2.5}$ join, the single-phase compositions attained in air at $850^{\circ} \mathrm{C}$. Oxidation of oxides containing 5 to $30 \% \mathrm{Pu}$ in air results in the formation of some U(VI), and cation disproportionation occurs; the lines have been drawn on the ternary phase diagram from the experimental results. The single orthorhombic phase has been drawn when the Pu content is less than $5 \%$.

At room temperature, the substoichiometric dioxide has been drawn to begin when the $\mathrm{Pu}$ content is $30 \%$, from the metallographic and $\mathrm{X}$-ray examinations of Blank et al. [119]; other X-ray lattice parameter data place this point between 30 and $40 \% \mathrm{Pu}$ [127].

The high-temperature lattice parameter data of Markin and Street [127] have been used to construct the ternary phase diagram at 400 , 600 and $800^{\circ} \mathrm{C}$.

No detailed work has been reported for high concentrations of $\mathrm{Pu}$, above $90 \%$, but the ternary phase diagram for the condition that nearly 
all the $\mathrm{Pu}$ has been reduced to $\mathrm{Pu}$ (III) must be complex since reduction of pure $\mathrm{PuO}_{2}$ to $\mathrm{PuO}_{1.5}$ results in a structural rearrangement to form hexagonal $\mathrm{Pu}_{2} \mathrm{O}_{3}$. Dashed lines have been drawn on the ternary phase diagram to be consistent with the $\mathrm{Pu}-\mathrm{O}$ phase diagram and the suggestion [9] that the hexagonal phase is suppressed when the $U$ content is greater than $5 \%$.

The phase diagram between $\mathrm{MO}_{2}$ and $\mathrm{M}_{3} \mathrm{O}_{8-\mathrm{y}}$ has been constructed for $\mathrm{Pu}$ concentrations below 30\% from the results of Dean [9] and Markin and Street [127]. A narrow single-phase region has been drawn at $\mathrm{M}_{4} \mathrm{O}_{9}$ for oxides with more than $15 \% \mathrm{Pu}$. The phase boundary for the $\mathrm{M}_{4} \mathrm{O}_{9}$ phase in equilibrium with $\mathrm{M}_{3} \mathrm{O}_{8-\mathrm{y}}$ has been drawn between $\mathrm{U}_{4} \mathrm{O}_{9}$ and $\left(\mathrm{U}_{0.5} \mathrm{Pu}_{0.5}\right) \mathrm{O}_{2.25}$, the $\mathrm{M}_{4} \mathrm{O}_{9}$ composition when the $\mathrm{U}$ valency is five. This composition has been taken to be the limit of the order-disorder transition for $\mathrm{M}_{4} \mathrm{O}_{9}-\mathrm{MO}_{2+x}$ The upper and lower phase boundaries of the $\mathrm{M}_{4} \mathrm{O}_{9}+\mathrm{MO}_{2+\mathrm{x}}$ two-phase region have been drawn as dashed lines from $15 \% \mathrm{Pu}$ to the order-disorder transition at $\left(\mathrm{U}_{0.5} \mathrm{Pu}_{0.5}\right) \mathrm{O}_{2.25}$.

A narrow single-phase $\mathrm{M}_{3} \mathrm{O}_{8-\mathrm{y}}$ region has been drawn on the phase diagram to a $\mathrm{Pu}$ content of about $35 \%$. Tie lines for 11,15 and $30 \% \mathrm{Pu}$ in the two-phase $\mathrm{M}_{4} \mathrm{O}_{9}+\mathrm{M}_{3} \mathrm{O}_{8-\mathrm{y}}$ region have been drawn along lines of constant $\mathrm{U} / \mathrm{Pu}$ ratio because the lattice parameter of the $\mathrm{M}_{4} \mathrm{O}_{9}$ phase in equilibrium with $\mathrm{M}_{3} \mathrm{O}_{8-\mathrm{y}}$ is independent of the oxygen content. Lattice parameter measurements have been made for partially oxidized samples of $\mathrm{UO}_{2}-\mathrm{ThO}_{2}[134]$ and the authors interpreted their data as a cation disproportionation reaction occurring between $\mathrm{U}_{3} \mathrm{O}_{8}$ and the $\mathrm{M}_{4} \mathrm{O}_{9}$ phase (referred to as face-centred cubic in their paper) below $50 \% \mathrm{Th}$, although the lattice parameter data show that the $\mathrm{U}_{3} \mathrm{O}_{8}$ contains several per cent of Th. A similar interpretation does not fit the data for the U-Pu-O system below $30 \% \mathrm{Pu}$, although the phase diagrams for $\mathrm{U}-\mathrm{Pu}-\mathrm{O}$ and $\mathrm{U}-\mathrm{Th}-\mathrm{O}$ are similar when the uranium content is less than $50 \%$. Oxides with $\mathrm{O} / \mathrm{M}$ ratios between 2.18 and 2.25 were two phase when the Th content was between 10 and $50 \%$ if the oxide was allowed to cool slowly to room temperature after oxidation; this result is in agreement with the postulated U-Pu-O phase diagram for $\mathrm{Pu}$ contents between 15 and 50\%.

\section{THERMODYNAMIC PROPERTIES}

Only one group of workers have obtained thermodynamic data for the mixed $(\mathrm{U}, \mathrm{Pu})$ oxides. Markin and McIver [122] have used the high temperature EMF cell, reversible to oxygen ions for $\mathrm{U}_{0.89} \mathrm{Pu}_{0.11} \mathrm{O}_{2 \pm \mathrm{x}}$ and $\mathrm{U}_{0.70} \mathrm{Pu}_{0.30} \mathrm{O}_{2 \pm \mathrm{x}}$ close to the stoichiometric composition at temperatures between 750 and $1100^{\circ} \mathrm{C}$. There are no other data for the (U, Pu) oxides with which to compare these results but the EMF cell used by Markin and McIver has been shown to give meaningful and reproducible results when thermodynamic data for the systems $\mathrm{UO}_{2+\mathrm{x}}[135], \mathrm{CeO}_{2-\mathrm{x}}$ and $\mathrm{PuO}_{2-x}\left(\right.$ at $\left.1050^{\circ}\right)[135,136]$ obtained from cell measurements, have been compared with data for these systems employing other methods. The EMF cell used to obtain data for the mixed oxides was identical with the cell used to obtain the $\mathrm{PuO}_{2-x}$ and $\mathrm{CeO}_{2-x}$ data. Pellets were analysed as for the U-Pu-O ternary phase diagram experiments. 


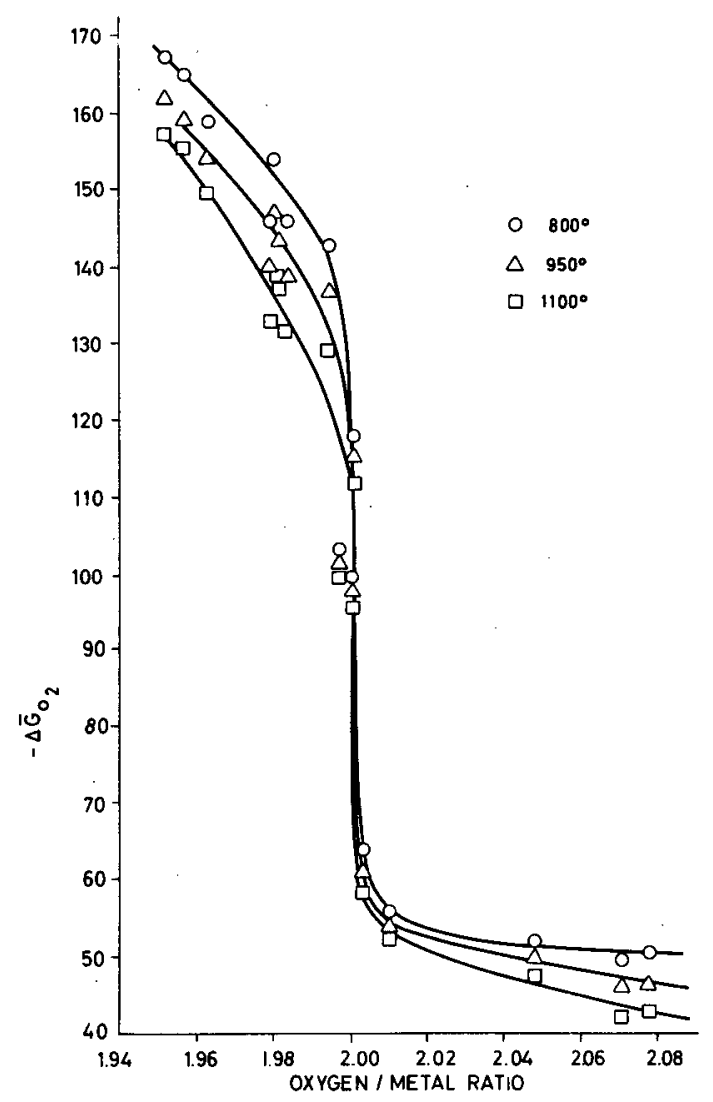

FIG. 14. $\Delta \overline{\mathrm{G}}_{\mathrm{O}_{2}}$ versus oxygen/metal ratio for $\mathrm{U}_{0,89} \mathrm{Pu}_{0,11} \mathrm{O}_{2 \pm \mathrm{X}}$.

Figures 14 and 15 show plots of $\Delta \overline{\mathrm{G}}_{\mathrm{O}_{2}}$ isotherms versus $\mathrm{O} / \mathrm{M}$ ratio for oxides containing 11 and $30 \% \mathrm{Pu}$. A very large change in $\Delta \overline{\mathrm{G}}_{\mathrm{O}_{2}}$ occurs when $\mathrm{MO}_{1.99}$ is oxidized to $\mathrm{MO}_{2.01}$ and the obvious inference is that the stoichiometric composition occurs at the steepest part of the curve, close to $\Delta \bar{G}_{\mathrm{O}_{2}}=-100 \mathrm{kcal}$, thus justifying the original definition of the stoichiometric composition as the oxide resulting after equilibration with a $10 / 1, \mathrm{CO} / \mathrm{CO}_{2}$ gas mixture at $850^{\circ} \mathrm{C}$.

Figures 16 and 17 show plots of $\Delta \overline{\mathrm{G}}_{\mathrm{O}_{2}}$ isotherms versus $\mathrm{Pu}$ valency for substoichiometric oxides and $U$ valency for superstoichiometric oxides respectively. It can be seen that $\Delta \overline{\mathrm{G}}_{\mathrm{O}_{2}}$ values for $\mathrm{U}_{0.89} \mathrm{Pu}_{0.11} \mathrm{O}_{2 \pm x}$, $\mathrm{U}_{0.85} \mathrm{Pu}_{0.15} \mathrm{O}_{2-\mathrm{x}}, \mathrm{U}_{0.70} \mathrm{Pu}_{0.30} \mathrm{O}_{2 \pm \mathrm{x}}$ and $\mathrm{UO}_{2+\mathrm{x}}$ fall on the same curves when plotted versus valency. This is extremely fortunate because it allows the $\Delta \overline{\mathrm{G}}_{\mathrm{O}_{2}}$ values for all single-phase (U, Pu) oxides containing between 10 and $30 \% \mathrm{Pu}$ to be predicted; presumably Fig. 17 may be extended to solid solutions outside this range, as long as the oxide remains single phase. However, for reasons discussed below, the $\Delta \overline{\mathrm{G}}_{\mathrm{O}_{2}}$ values for $\mathrm{PuO}_{2-\mathrm{x}}$ do not, in general, fall on the curve in Fig. 16 


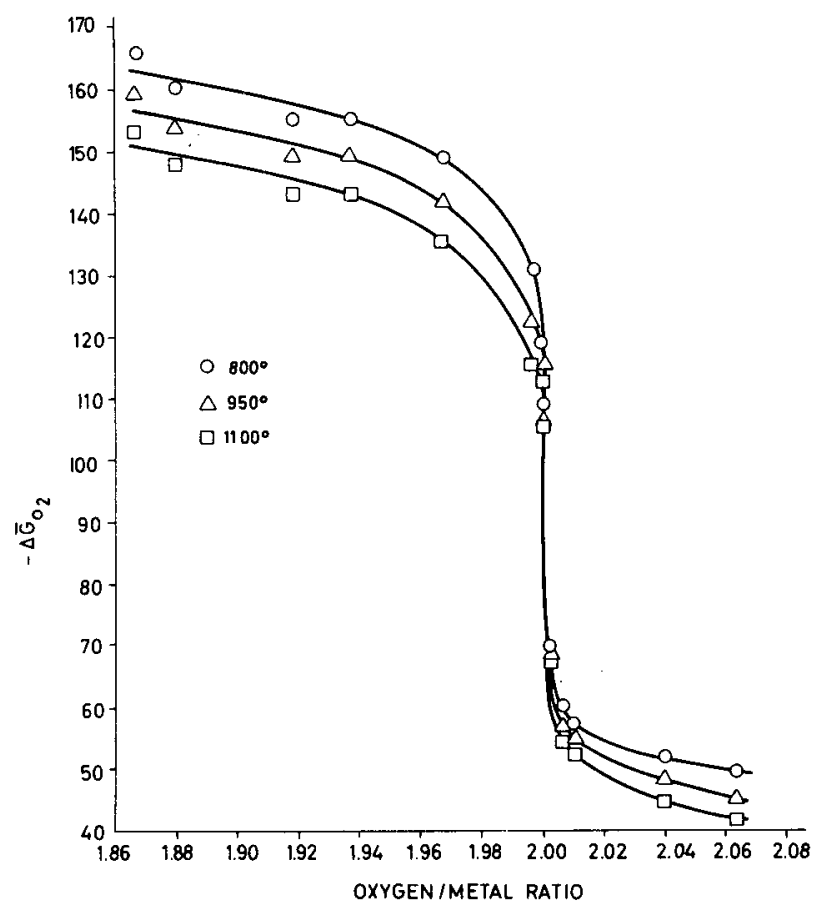

FIG. 15. $\Delta \bar{G}_{\mathrm{O}_{2}}$ versus oxygen/metal ratio for $\mathrm{U}_{0.70} \mathrm{Pu}_{0,30} \mathrm{O}_{2 \pm \mathrm{x}}$.

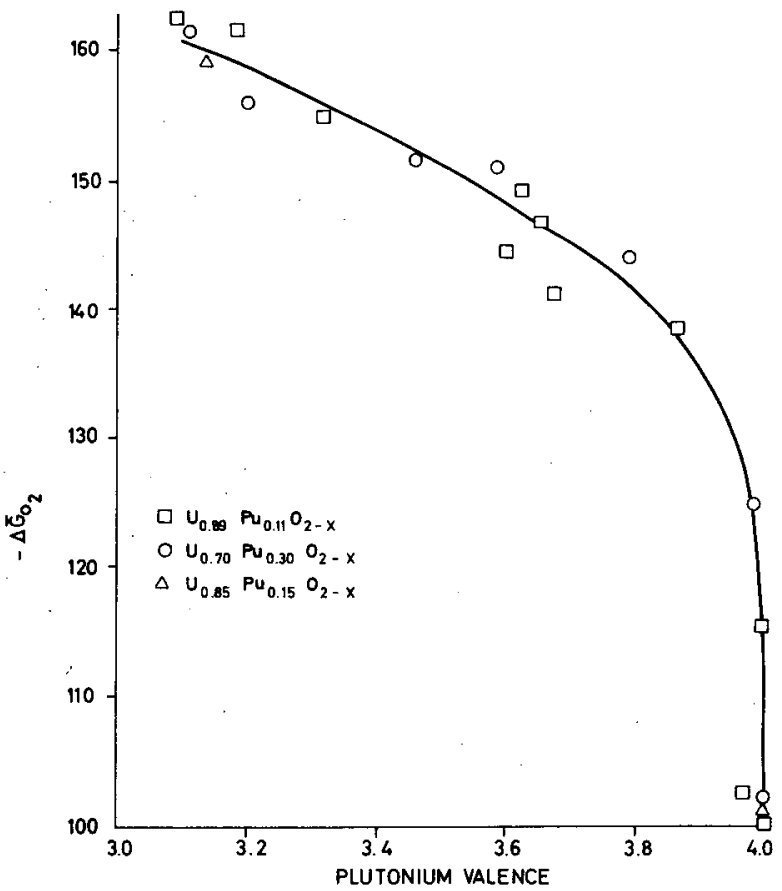

FIG. 16. $\Delta \bar{G}_{\mathrm{O}_{2}}$ at $1173^{\circ} \mathrm{K}$ versus plutonium valence for (U, $\mathrm{Pu}$ ) $\mathrm{O}_{2}-\mathrm{x}$. 


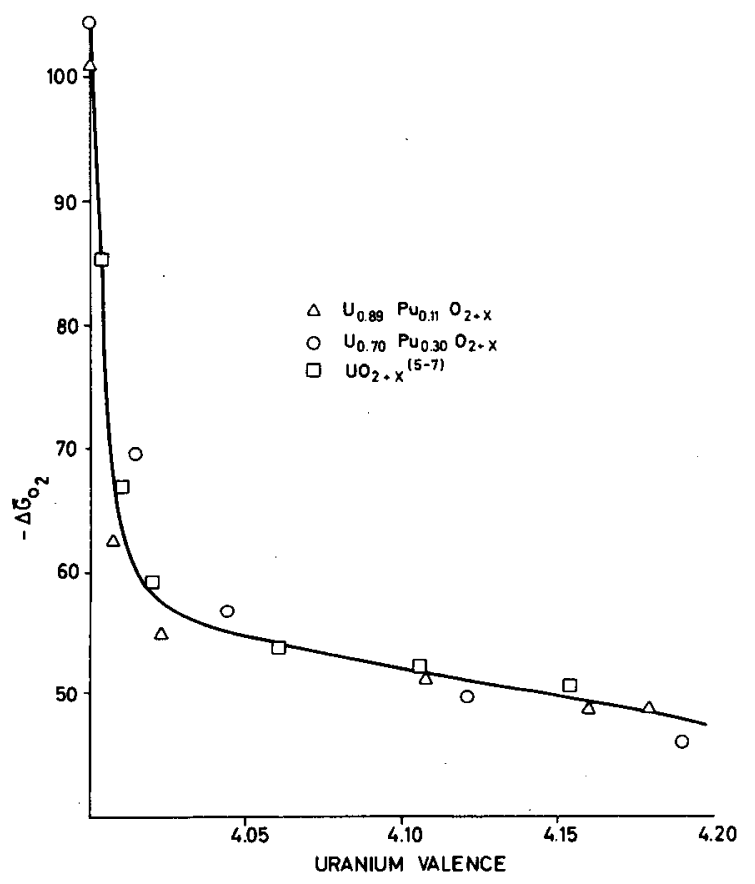

FIG. 17. $\Delta \bar{G}_{\mathrm{O}_{2}}$ at $1173^{\circ} \mathrm{K}$ versus uranium valence for $(\mathrm{U}, \mathrm{Pu}) \mathrm{O}_{2+\mathrm{x}}$ and $\mathrm{UO}_{2}+\mathrm{x}$.

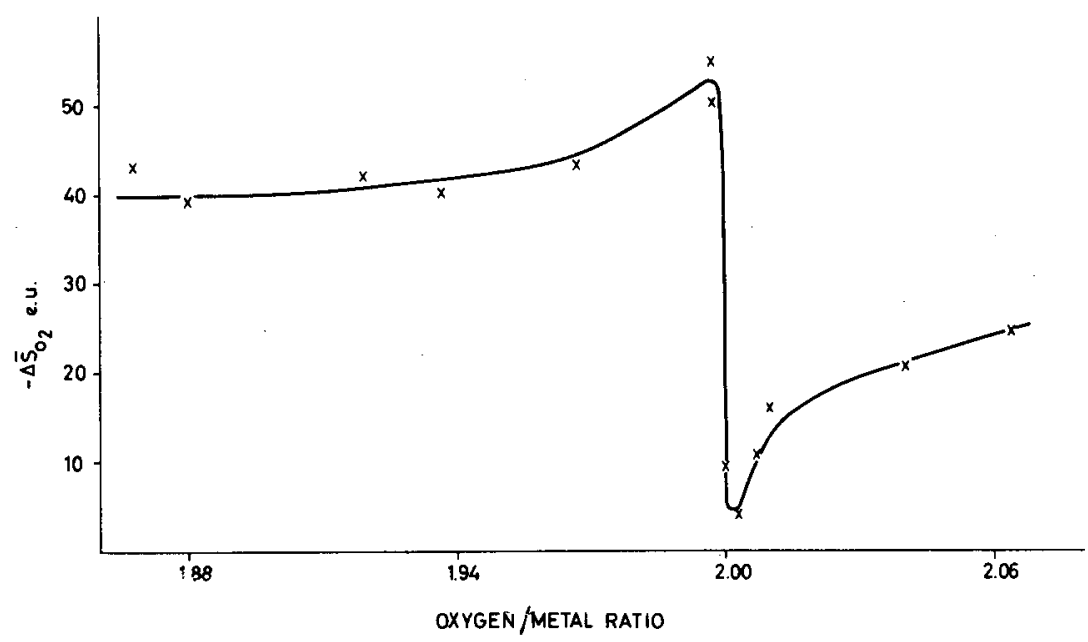

FIG. 18. $\Delta \overline{\mathrm{S}}_{\mathrm{O}_{2}}$ versus oxygen/metal ratio for $\mathrm{U}_{0.70} \mathrm{Pu}_{0.30} \mathrm{O}_{2 \pm \mathrm{X}}$ *

(by chance, the values are not far different at $1173^{\circ} \mathrm{K}$, the temperature for which Fig. 16 is drawn; this is not so at other temperatures). The figure should therefore not be used much outside the range 10 to $30 \% \mathrm{Pu}$ without corroboration, particularly as results on the similar $\mathrm{U}-\mathrm{Ce}-\mathrm{O}$ 


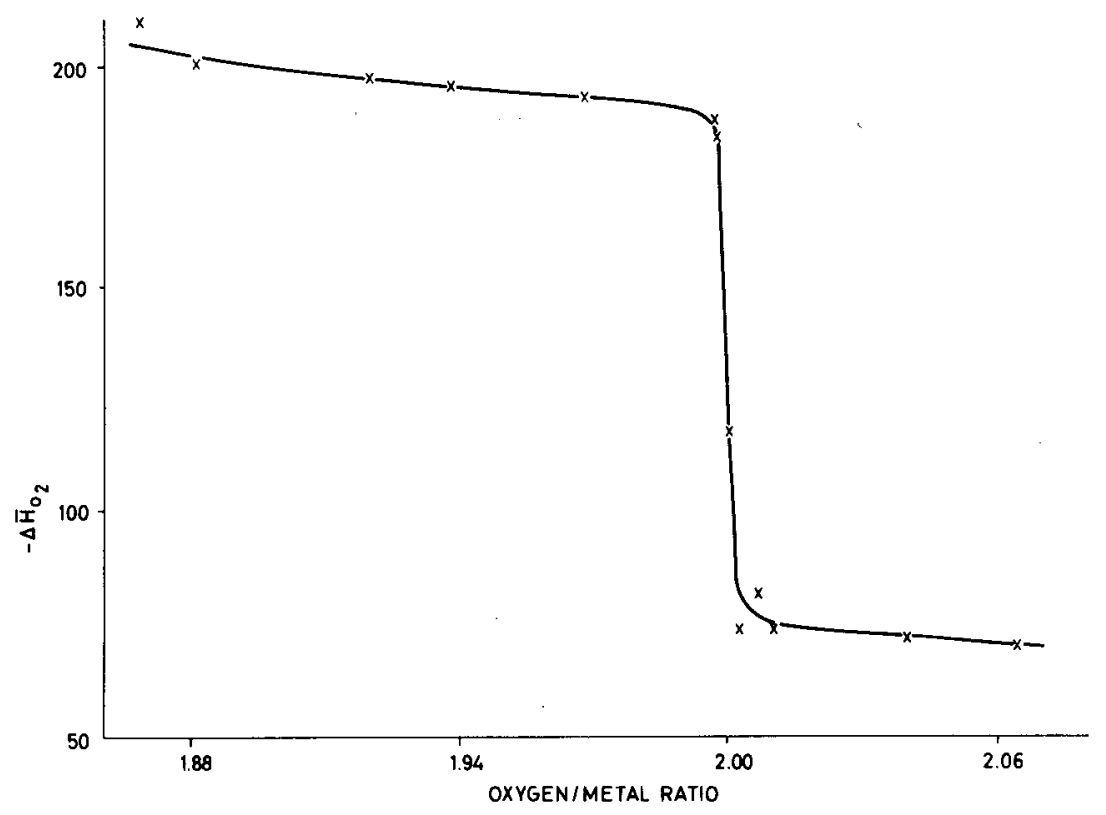

FIG. 19. $\Delta \overline{\mathrm{H}}_{\mathrm{O}_{2}}$ versus oxygen/metal ratio for $\mathrm{U}_{0,70} \mathrm{Pu}_{0.30} \mathrm{O}_{24 \mathrm{x}} \cdot$

system [137] show that $\Delta \overline{\mathrm{G}}_{\mathrm{O}_{2}}$ is not the same function of Ce valency between 35 and $75 \% \mathrm{Ce}$ as between 10 and $15 \% \mathrm{Ce}$.

Figures 18 and 19 show the variation of $\Delta \overline{\mathrm{S}}_{\mathrm{O}_{2}}$ and $\Delta \overline{\mathrm{H}}_{\mathrm{O}_{2}}$ with $\mathrm{O} / \mathrm{M}$ ratio for $\mathrm{U}_{0.70} \mathrm{Pu}_{0.30} \mathrm{O}_{2 \pm \mathrm{x}}$. Similar plots have been obtained for $\mathrm{U}_{0.89} \mathrm{Pu}_{0.11} \mathrm{O}_{2 \pm \mathrm{x}}$. The values for $\mathrm{x}>0$ are very similar to those for $\mathrm{UO}_{2+\mathrm{x}}$ but for $\mathrm{x}<0, \Delta \overline{\mathrm{H}}_{\mathrm{O}_{2}}$ and $\Delta \overline{\mathrm{S}}_{\mathrm{O}_{2}}$ show no similarity to the corresponding values for $\mathrm{PuO}_{2-\mathrm{x}}$. The variation of $\Delta \overline{\mathrm{H}}_{\mathrm{O}_{2}}$ with composition for (U, $\mathrm{Pu}$ ) oxides was small, no more than $10 \mathrm{kcal}$ as the $\mathrm{Pu}$ valency was reduced from 4.0 to 3.1 , in sharp contrast to the change of $80 \mathrm{kcal}$ in going from $\mathrm{PuO}_{2}$ to $\mathrm{PuO}_{1.75}$ (i.e. a change of valency from 4.0 to 3.5 ).

Markin and Roberts [136] have considered the reason for the difference between $(\mathrm{U}, \mathrm{Pu}) \mathrm{O}_{2-x}$ and $\mathrm{PuO}_{2-x}$. The oxygen vacancies in $\mathrm{PuO}_{2-x}$ were assumed to agglomerate locally to form regions having the structure of a stable oxide; this can only occur if a large fraction of the cations can take part in this co-operative mechanism leading to local ordering. The U(IV) ions cannot take part in this process unless, of course, they are reduced to U(III). The behaviour of solid solutions of $(\mathrm{U}, \mathrm{Pu}) \mathrm{O}_{2}$ suggests that oxygen is removed from the same environment at all compositions. This may be oxygen sites between two $\mathrm{Pu}$ atoms, with localization of the charge. Even at $11 \% \mathrm{Pu}, 80 \%$ of the $\mathrm{Pu}$ atoms have a $\mathrm{Pu}$ atom as one nearest neighbour. It was pointed out in the same paper that measurements on a wider range of $\mathrm{Pu}$ content would be instructive because the $\mathrm{Pu}$ concentration at which a significant change in behaviour occurred might indicate the number of $\mathrm{Pu}$ atoms involved in co-operative local ordering. 


\section{VAPORIZATION BEHAVIOUR}

The partial vapour pressures of $\mathrm{UO}_{2}$ and $\mathrm{PuO}_{2}$ in equilibrium with solid (U, Pu) $\mathrm{O}_{2}$ have been measured [21] recently for three compositions: 10,20 and $25 \% \mathrm{Pu}$, in the temperature range of $1800-2500^{\circ} \mathrm{K}$. The use of $233 \mathrm{U}$ for the composition $20 \% \mathrm{Pu}$ permitted the direct measurement by alpha counting of $U$ deposited on the target. In the other two cases, where the samples were made with natural uranium, uranium on the target was determined by X-ray fluorescence.

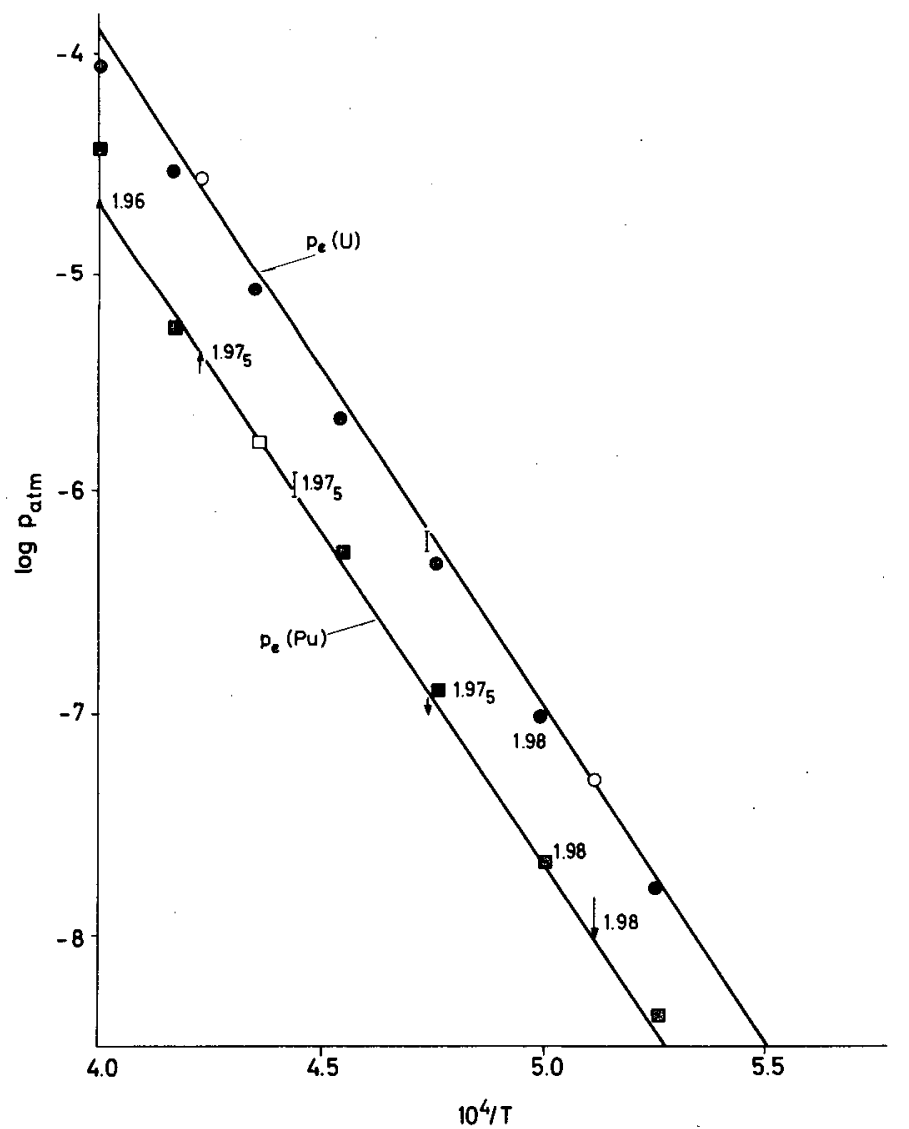

FIG.20. Total pressures of uranium- $\left(\mathrm{P}_{\mathrm{e}}(\mathrm{U})\right)$ and plutonium- $(\mathrm{Pe}(\mathrm{Pu}))$ bearing species over $\mathrm{U}_{0.9} \mathrm{Pu}_{0.1} \mathrm{O}_{2-\mathrm{x}}$. Initial oxygen $/$ metal ratio $=1.983$.

$$
\begin{aligned}
& \downarrow \circ \mathrm{Pe}_{\mathrm{e}}(\mathrm{U}) \text { experimental } \\
& -\mathrm{Pe}_{\mathrm{e}}(\mathrm{U}) \text { calculated }
\end{aligned}
$$

$$
\begin{aligned}
& \uparrow \square \mathrm{p}_{\mathrm{e}}(\mathrm{Pu}) \text { experimental } \\
& -\mathrm{p}_{\mathrm{e}}(\mathrm{Pu}) \text { calculated }
\end{aligned}
$$

The results are represented on Figs 20 and 21 for two compositions, 10 and $20 \% \mathrm{Pu}$. As for pure $\mathrm{PuO}_{2}$, the partial vapour pressures are time dependent. Consequently, targets were exposed at successive times up to apparent steady-state conditions. The arrows on the figures indicate the extent of this pressure change at fixed temperature. Figures near the experimental points give the final $\mathrm{O} / \mathrm{M}$ ratio of the solid corresponding 


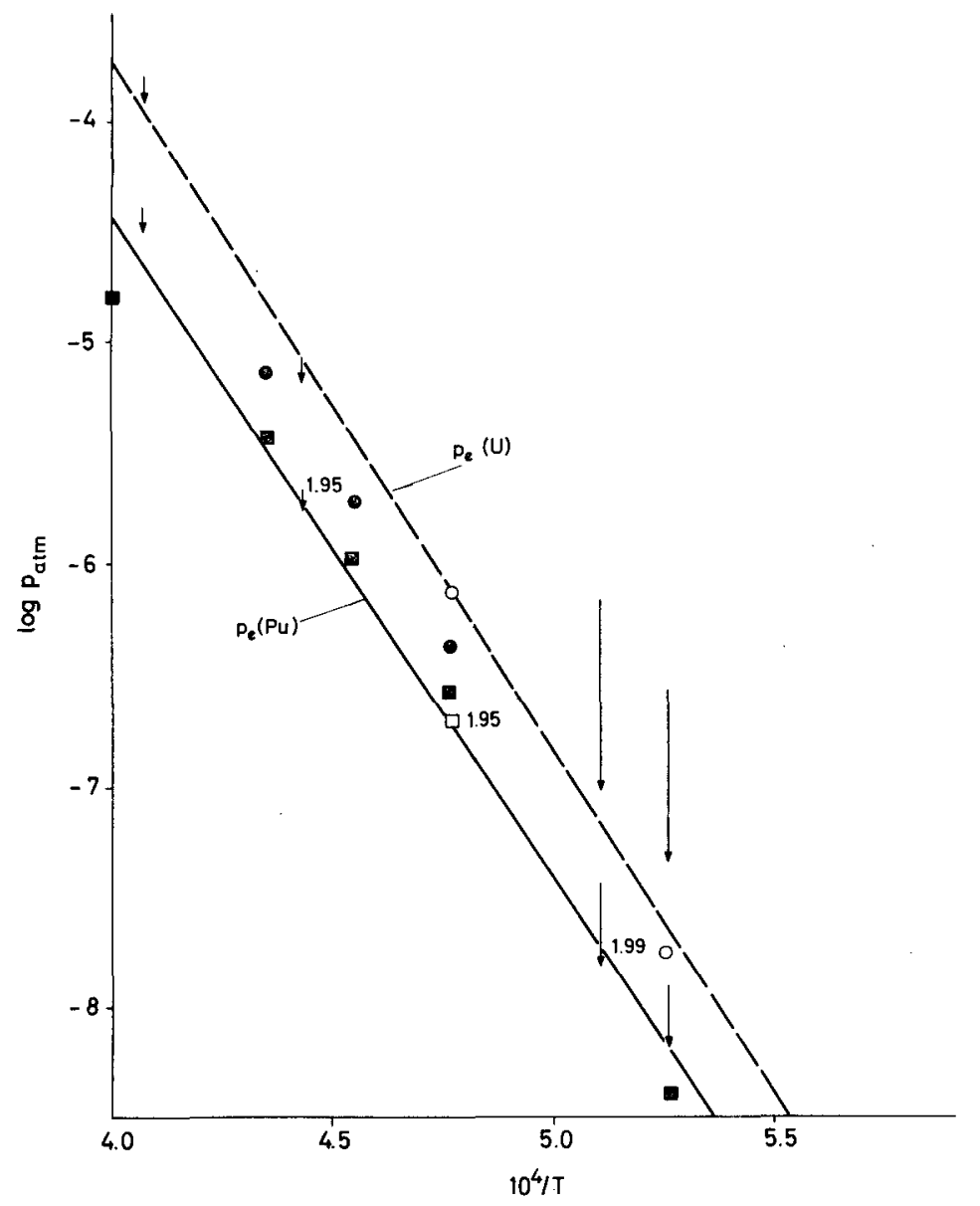

FIG.21. Total pressures of uranium- $\left(\mathrm{P}_{\mathrm{e}}(\mathrm{U})\right)$ and plutonium- $\left(\mathrm{P}_{\mathrm{e}}(\mathrm{Pu})\right)$ bearing species over $\mathrm{U}_{0.8} \mathrm{Pu}_{0.2} \mathrm{O}_{2-\mathrm{x}}$. Initial oxygen $/$ metal ratio $=2.00$.

$$
\begin{aligned}
& \downarrow \circ \mathrm{Pe}_{\mathrm{e}}(\mathrm{U}) \text { experimental } \\
& -\mathrm{P}_{\mathrm{e}}(\mathrm{U}) \text { calculated }
\end{aligned}
$$$$
\begin{aligned}
& \downarrow \square \mathrm{P}_{\mathrm{e}}(\mathrm{Pu}) \text { experimental } \\
& \square \mathrm{Pe}_{\mathrm{e}}^{(\mathrm{Pu})} \text { calculated }
\end{aligned}
$$

to the apparent equilibrium. These $\mathrm{O} / \mathrm{M}$ values have been deduced from the increase of the lattice parameter with respect to that of the stoichiometric product. Sufficient thermodynamic data are now available ([63,116] and Section II.4) to calculate the total pressure and composition of the vapour over substoichiometric mixed oxides. With the known free energies of formation of the gaseous species ( $\mathrm{UO}, \mathrm{UO}_{2}, \mathrm{UO}_{3}, \mathrm{PuO}$ and $\mathrm{PuO}_{2}$ ) and known oxygen pressures (Section III.3) the only assumption required is that $\mathrm{UO}_{2}$ and $\mathrm{PuO}_{2-x}$ form ideal solid solutions. This assumption is likely to be valid when $\mathrm{x}$ is close to zero, since Aitken et al. $[138,139]$ have shown that $\mathrm{UO}_{2}$ and $\mathrm{ThO}_{2}$ do form ideal solid solutions, but $\mathrm{UO}_{2}$ and $\mathrm{Y}_{2} \mathrm{O}_{3}$ do not. The calculated points [140] for the total uranium- and plutonium-bearing species are shown in Figs 20 and 21. The agreement is indeed excellent.

It will be seen from Fig. 21 that the initial uranium-bearing pressures over stoichiometric $\mathrm{U}_{0.8} \mathrm{Pu}_{0.2} \mathrm{O}_{2.00}$ are remarkably high in the lower 
temperature range, around $2000^{\circ} \mathrm{K}$. Initially the pressure is about ten times that of pure $\mathrm{UO}_{2}$ and even at the end of the run, when apparent equilibrium had been reached, it is significantly higher than for $\mathrm{UO}_{2}$. This phenomenon is due to the relatively high oxygen potentials over the mixed oxides (Section III. 3), these being several orders of magnitude higher than that over $\mathrm{UO}_{2}$. Under these conditions the $\left(\mathrm{UO}_{2}\right)+(\mathrm{O}) \rightarrow\left(\mathrm{UO}_{3}\right)$ equilibrium lies far to the right, and thus $\left(\mathrm{UO}_{3}\right)$ is the principal uraniumbearing species over stoichiometric mixed oxides, which in this respect behave as would solutions of $\mathrm{UO}_{2+\mathrm{x}}$ and $\mathrm{PuO}_{2-\mathrm{x}}$. The observed initial pressure would correspond to $\mathrm{UO}_{2.04}$. Conversely, of course, the principal plutonium-bearing species over highly substoichiometric mixed oxides is (PuO); calculation shows that over $\mathrm{U}_{0.8} \quad \mathrm{Pu}_{0.2} \mathrm{O}_{1.95}$ the (PuO) partial pressure is ten times that of $\left(\mathrm{PuO}_{2}\right)$.

\section{CONCLUSIONS AND FUTURE WORK}

The phase diagram for low concentrations of $\mathrm{Pu}$ (below 30\%) is fairly well established for both the super-and substoichiometric compositions, since these are the $\mathrm{Pu}$ concentrations of interest to the reactor chemist. More work is required to fix the $\mathrm{MO}_{2}+\mathrm{MO}_{2-\mathrm{x}}$ phase boundary at a precise $\mathrm{Pu}$ composition; at present the boundary can only be placed near $30 \% \mathrm{Pu}$. The $\mathrm{M}_{4} \mathrm{O}_{9}+\mathrm{M}_{3} \mathrm{O}_{8-y}$ two-phase region for oxides containing 35 to $50 \% \mathrm{Pu}$ must be investigated to determine whether cation disproportionation does occur in accordance with the postulated phase diagram. Some very careful work is needed to define the homogeneity range and $\mathrm{Pu}$ concentration limit of the single-phase $\mathrm{M}_{3} \mathrm{O}_{8-\mathrm{y}}$ region. Superstructure lines in the $\mathrm{X}$-ray pattern of the $\mathrm{M}_{4} \mathrm{O}_{9}$ phase should be looked for. The evidence to date suggests that superstructure lines appear only after the oxide has been heated to 1000 to $1400^{\circ} \mathrm{C}$ when the cation mobility becomes sufficiently high to allow the cations to order. The phase diagram for oxides containing more than $90 \% \mathrm{Pu}$ needs very careful examination and this may throw more light on the $\mathrm{Pu}-\mathrm{O}$ phase diagram for the pure plutonium system.

The cause of the differences in lattice parameter of the fully reduced oxides containing less than $30 \% \mathrm{Pu}$ is not known (Fig.11). Analyses showed that all the Pu had been reduced to Pu(III) in all cases. Measurement of the lattice parameter of the fully reduced oxide, prepared by $\mathrm{H}_{2}$ reduction of co-precipitated and physically mixed oxide at the same temperature and under the same conditions, may help to explain the large differences in lattice parameter. The Panel did not believe that the differences were due to lack of homogeneity but could offer no alternative explanation.

It is very gratifying to note that the thermodynamic data for the solid ( $\mathrm{U}, \mathrm{Pu}$ ) oxides obtained from the EMF cell, extrapolated to higher temperatures, together with the vaporization data for uranium and plutonium oxides, are consistent with the vaporization data of Pascard. However, vaporization data for only three compositions are available, and although these agree well with the calculated values some more results for different compositions are desirable. 


\section{OTHER $\mathrm{PuO}_{2}-\mathrm{MeO}_{\mathrm{x}}$ OXIDE SYSTEMS}

Very few thermochemical properties of the binary plutonium oxidemetal oxide systems are described in the literature. Some phase diagrams and relevant basic data (melting points, $X$-ray analysis, ceramographic studies) are available, but practically no thermochemical data are given. The same situation is found with the ternary plutonium-metal-oxides.

In nearly all the reported systems there is grave doubt about the actual valency of the plutonium. The simple eutectic systems or the systems of continuous solid solutions contain Pu(IV). Pu(III) or usually both, depending on the experimental conditions. The ternary oxides (using the nomenclature of Keller [141], i.e. those in which compound formation is possible, contain the plutonium in various valency states up to six. Unfortunately this problem is very rarely discussed explicitly in the published papers. Most investigators used sintering at $1500-1600^{\circ} \mathrm{C}$ in inert atmospheres, which will usually result in reduction of the plutonium, so that the results are not fully representative of the $\mathrm{Pu}(\mathrm{IV})$ system.

\section{BINARY SYSTEMS $\mathrm{PuO}_{2}-\mathrm{MeO}_{\mathrm{x}}$}

\subsection{Simple eutectic systems}

Eutectic composition, temperature and terminal solubility limits have been reported for the systems $\mathrm{BeO}-\mathrm{PuO}_{2}$ (by Hough and Marples [142] and Dayton and Paprocki (143-147]), $\mathrm{MgO}-\mathrm{PuO}_{2}$ (by Carroll [148]), $\mathrm{Al}_{2} \mathrm{O}_{3}-\mathrm{PuO}_{2}$ (by Hough and Marples [142]) and $\mathrm{SiO}_{2}-\mathrm{PuO}_{2}$ (by Carroll [149]) (see Table XV). Hough and Marples [142] used the most oxidizing conditions (oxygen atmosphere inside a thoria tube) and their data are to be preferred at present.

The phase diagram of $\mathrm{MgO}-\mathrm{PuO}_{2}$ described by Carroll [148] (Fig. 22) must be regarded as preliminary only because of the large impurity content $\left(\mathrm{PuO}_{1,52}, \mathrm{MgWO}_{4}, \mathrm{WO}_{3}\right.$ and $\left.\mathrm{W}\right)$ found by X-ray diffraction.

The surprisingly high terminal solubility of $\mathrm{MgO}$ in $\mathrm{PuO}_{2}$ $(3.2 \pm 1.5 \mathrm{~mole} \%$ ) found by Hough and Marples [142] could be explained by the small counting rate obtained on the microprobe and by a large "atomic number", correction [142].

The perovskite type compound $\mathrm{PuA}_{10}$ described by Russell et al. [151] and McEwen [152] was prepared in reducing atmospheres and contains only $\mathrm{Pu}(\mathrm{III})$. Runnalls [153] has shown that its structure is [151] orthorhombic and not rhombohedral as first reported [151].

The ternary system $\mathrm{BeO}-\mathrm{ThO}_{2}-\mathrm{PuO}_{2}$ was studied by Pardue et al., reported by Dayton and Paprocki [147] and by Hough and Marples [142], who have drawn part of the ternary phase system (Fig. 23) showing the 
œ TABLE XV. EUTECTIC AND TERMINAL SOLID SOLUBILITY DATA FOR BeO-PuO $2, \mathrm{MgO}_{2} \mathrm{PuO}_{2}$, $\mathrm{Al}_{2} \mathrm{O}_{3}-\mathrm{PuO}_{2}$ SYSTEMS

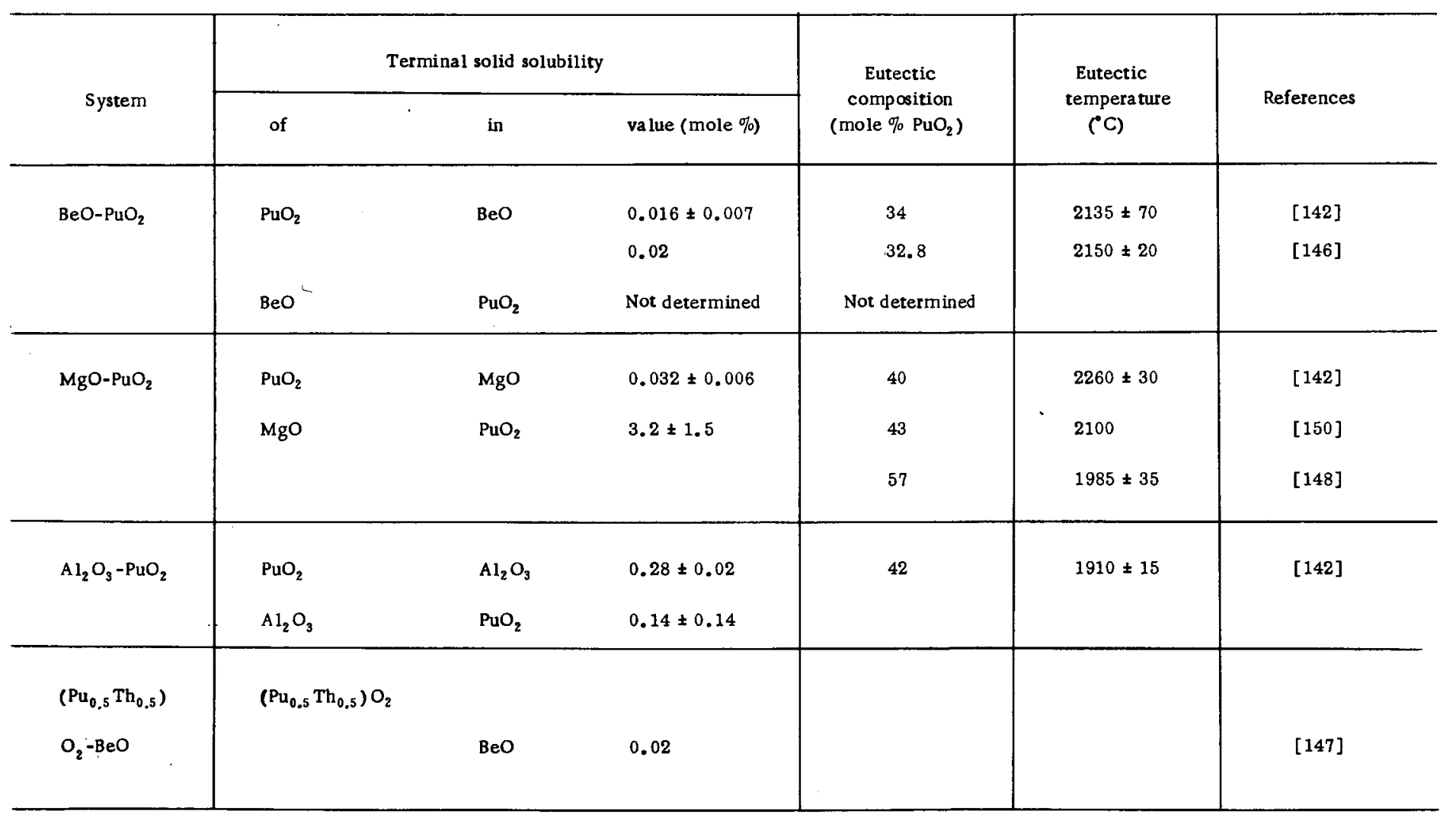




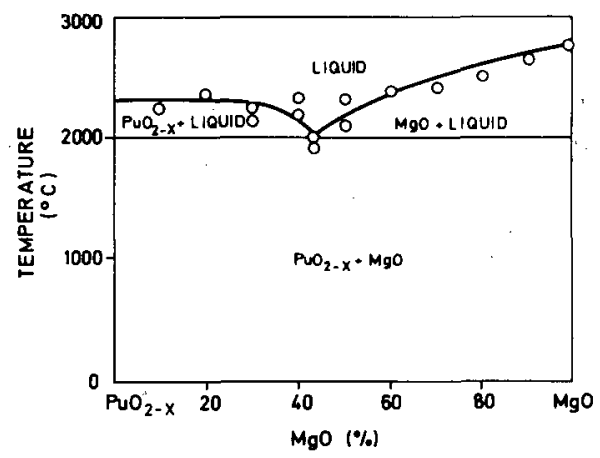

FIG.22. Proposed diagram for the system $\mathrm{PuO}_{2}-\mathrm{MgO}$.

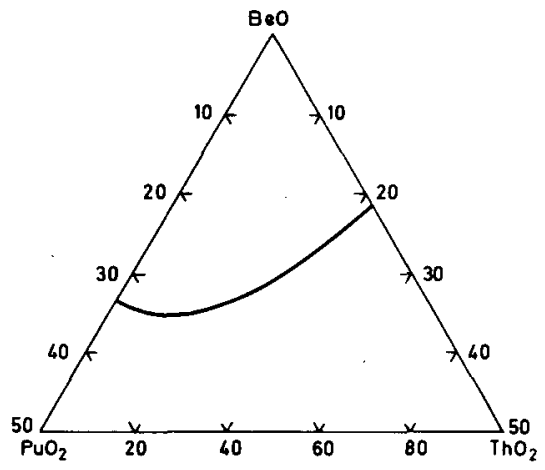

FIG.23. $\mathrm{PuO}_{2}-\mathrm{BeO}-\mathrm{ThO}_{2}$ system; position of eutectic valley.

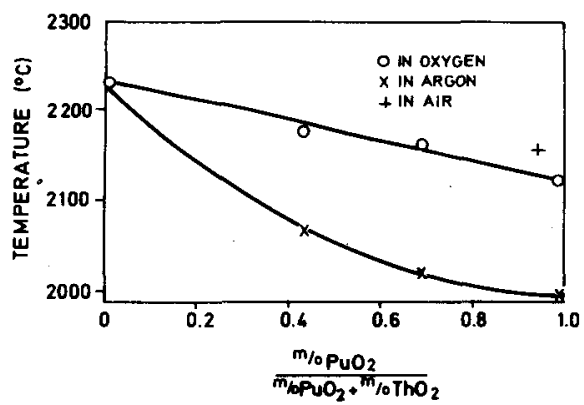

FIG.24. Melting points of $\mathrm{PuO}_{2}-\mathrm{BeO}-\mathrm{ThO}_{2}$ specimens along the eutectic valley in oxygen and in argon.

position of the eutectic valley. The experimental conditions used (oxyacetylene flame melting) probably exclude the possibility of the loss of oxygen from the plutonia.

Figure 24 shows the difference in melting points along the eutectic valley between the specimens treated in an oxygen and argon atmosphere [142], and includes one melting point (in air) determined by Pardue et al. (reported in [147]). 


\subsection{Continuous solid solutions}

\subsection{1. $\mathrm{CeO}_{2}-\mathrm{PuO}_{2}$}

Mulford and Ellinger [154] have published the lattice parameters for various compositions of $\mathrm{CeO}_{2}-\mathrm{PuO}_{2}$; Végard's $\mathrm{Law}$ is followed to within the accuracy of the measurements.

\subsection{2. $\mathrm{ZrO}_{2}-\mathrm{PuO}_{2}$}

The phase diagram was published by Carroll [156] (Fig. 25). A continuous range of fluorite-type solid solutions is evident from pure $\mathrm{PuO}_{2}$ to 77 mole $\% \mathrm{ZrO}_{2}$. The region from 77 to 99.8 mole $\% \mathrm{ZrO}_{2}$ contains two phases in equilibrium at room temperature, monoclinic $\mathrm{ZrO}_{2}$ and a facecentred cubic $\mathrm{PuO}_{2}-77$ mole \% $\mathrm{ZrO}_{2}$ solid solution.

FIG.25. The system $\mathrm{PuO}_{2}-\mathrm{ZrO}_{2}$.
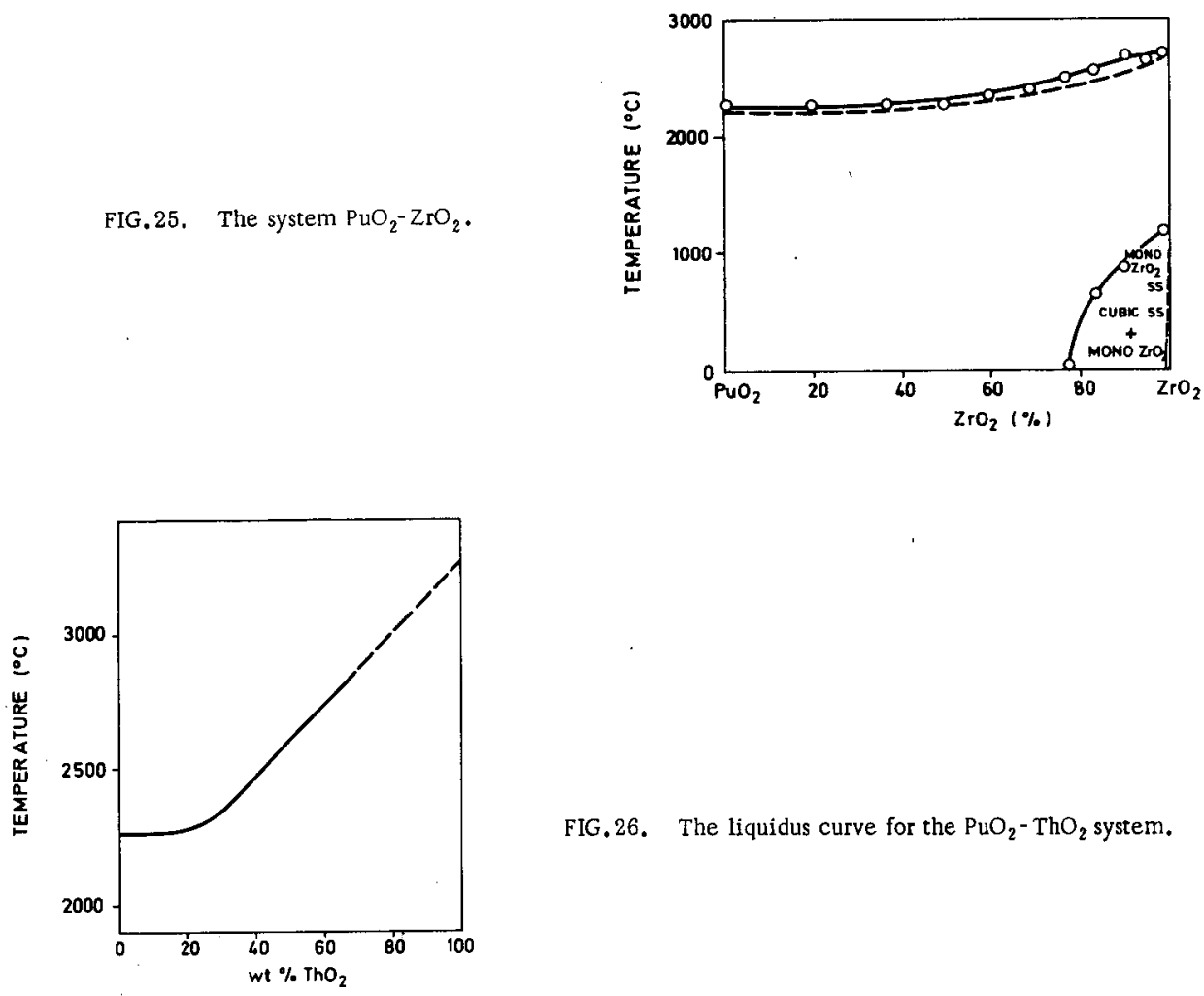

FIG.26. The liquidus curve for the $\mathrm{PuO}_{2}-\mathrm{ThO}_{2}$ system.

In addition to this, 0.2 mole $\% \mathrm{PuO}_{2}$ dimensionally stabilizes monoclinic $\mathrm{ZrO}_{2}$ and forms a special phase region [156]. However, all the specimens for this work were prepared by sintering in an inert gas at $1500-1550^{\circ} \mathrm{C}$, so that the precise oxidation state of the plutonium is unknown. This will also be true for Carroll's determinations of the melting points [156]. 
TABLE XVI. LATTICE PARAMETER OF THE EuO ${ }_{1.5}-\mathrm{PuO}_{2}$ SYSTEM

\begin{tabular}{|c|c|c|}
\hline $\mathrm{PuO}_{2}($ mole $\%)$ & $\begin{array}{l}\text { Lattice parameter } \\
\quad \&\end{array}$ & $\begin{array}{l}\text { Percentage of body-centred } \\
\text { cubic phase present }\end{array}$ \\
\hline 100.0 & $5.3938 \pm 0.0005$ & - \\
\hline 90.0 & $5.3935 \pm 0.0005$ & - \\
\hline 85.0 & $5.3934 \pm 0.0005$ & - \\
\hline 80.0 & $5.3974 \pm 0.0005$ & - \\
\hline 70.0 & $5.4055 \pm 0.0005$ & - \\
\hline 60.0 & $5.4138 \pm 0.0005$ & - \\
\hline 55.0 & $5.417 \pm 0.001$ & - \\
\hline 50.0 & $5.419 \pm 0.002$ & - \\
\hline 40.0 & $5.420 \pm 0.003$ & 5 \\
\hline 20.0 & $5.424 \pm 0.005$ & 20 \\
\hline
\end{tabular}

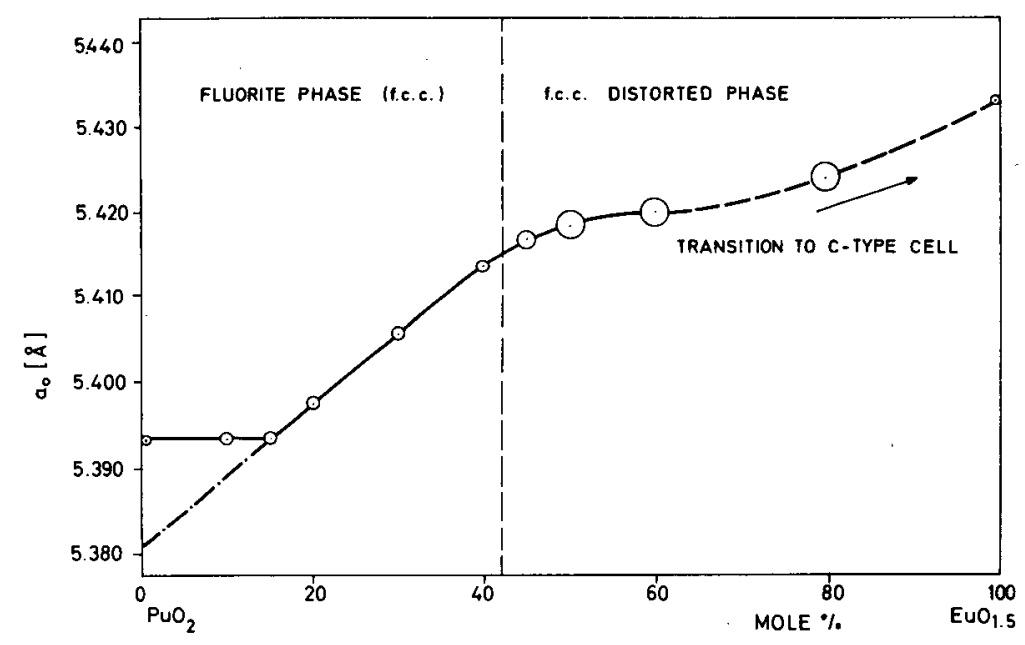

FIG. 27. Lattice parameter versus mole $\% \mathrm{PuO}_{2}\left(\mathrm{EuO}_{1.5}-\mathrm{PuO}_{2}\right.$ system).

\subsection{3. $\mathrm{ThO}_{2}-\mathrm{PuO}_{2}$}

Mulford and Ellinger [154] have shown from lattice parameter measurements that a continuous range of solid solutions, obeying Végard's Law, is formed. It seems likely that the materials prepared by Pardue et al. in argon near $1700^{\circ} \mathrm{C}$, which showed slight positive deviations from 
TABLE XVII. PHYSICO-CHEMICAL PROPERTIES OF THE TERNARY-QUATERNARY PLUTONIUM-METAL OXIDES

\begin{tabular}{|c|c|c|c|c|c|c|c|c|c|}
\hline \multirow{2}{*}{$\begin{array}{l}\text { Formula } \\
\text { valency state } \\
\text { of metal ions }\end{array}$} & \multicolumn{5}{|c|}{ The condition of preparation and thermal stability } & \multicolumn{2}{|c|}{ Structural date } & \multirow[b]{2}{*}{ References } & \multirow[b]{2}{*}{ Notes } \\
\hline & $\begin{array}{l}\text { Temperature of } \\
\text { crystal } \\
\text { formation } \\
\text { (C) }\end{array}$ & atm. & $\begin{array}{l}\text { Dwell } \\
\text { time }\end{array}$ & $\begin{array}{l}\text { Thermal } \\
\text { stability } \\
\text { limit }^{2} \\
\text { (C) }\end{array}$ & Purity & $\begin{array}{l}\text { Symmetry, } \\
\text { space group, } \\
\text { structure type }\end{array}$ & $\begin{array}{l}\text { Unit cell } \\
\text { dimensions } \\
(A)\end{array}$ & & \\
\hline $\mathrm{Li}_{4} \mathrm{Pu}^{\mathrm{VI}} \mathrm{O}_{5}$ & $\begin{array}{l}400-500 \\
\text { (up to } 900 \text { ) }\end{array}$ & $\mathrm{O}_{2}$ & $6 \mathrm{~h}$ & $\begin{array}{l}>900 \\
\text { dec. } \\
\mathrm{Li}_{3} \mathrm{Pu}^{\mathrm{V}_{4}}\end{array}$ & Pure & $\begin{array}{l}\text { Tetragonal } \\
\mathrm{I} 4 / \mathrm{m}\end{array}$ & $\begin{array}{l}a=6.677 \pm 0.002 \\
c=4.421 \div 0.003\end{array}$ & $\begin{array}{l}{[160]} \\
{[161]} \\
{[162]}\end{array}$ & \\
\hline $\mathrm{Li}_{6} \mathrm{Pu}^{\mathrm{VI}} \mathrm{O}_{5}$ & $400-500$ & $\mathrm{O}_{2}$ & & $\begin{array}{l}800 \\
\text { dec. } \\
\mathrm{Li}_{3} \mathrm{Pu}_{\mathrm{O}_{4}}\end{array}$ & Pure & Hexagonal & $\begin{array}{l}a=5.184 \\
c=14.59\end{array}$ & $\begin{array}{l}{[160]} \\
{[161]}\end{array}$ & \\
\hline $\mathrm{Li}_{3} \mathrm{Pu} \mathrm{VO}_{4}$ & 600 & $\mathrm{O}_{2}$ & $8 \mathrm{~h}$ & $\begin{array}{l}600 \\
\text { vacuum } \\
\text { dec. } \\
\mathrm{Li}_{7} \mathrm{Pu}^{\mathrm{V}_{\mathrm{O}}} \mathrm{O}_{6} \\
1100 \\
\text { dec. } \\
\mathrm{PuO}_{2}\end{array}$ & Pure & Tetragonal & $\begin{array}{l}a=4.464 \pm 0.002 \\
c=8.367 \pm 0.005\end{array}$ & [162] & \\
\hline $\mathrm{Li}_{7} \mathrm{Pu}^{\mathrm{V}} \mathrm{O}_{\mathrm{G}}$ & 600 & $\begin{array}{l}\text { Vacuum } \\
\text { Sealed bulb }\end{array}$ & & & Impure & $\begin{array}{l}\text { ? } \\
\mathrm{Li}_{7} \mathrm{BiO}_{8} \\
\text { type }\end{array}$ & & [162] & \\
\hline$\alpha-\mathrm{Na}_{4} \mathrm{Pu}^{\mathrm{VI}} \mathrm{O}_{5}$ & 400 & $\mathrm{O}_{2}$ & & 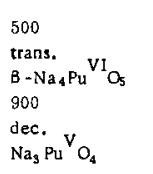 & Pure & $\begin{array}{l}\text { Cubic } \\
\text { Fm3n }\end{array}$ & $a=4.718 \pm 0,005$ & $\begin{array}{l}{[161]} \\
{[162]}\end{array}$ & \\
\hline
\end{tabular}




\begin{tabular}{|c|c|c|c|c|c|c|c|c|c|}
\hline $\mathrm{B}-\mathrm{Na}_{4} \mathrm{Pu} \mathrm{VI}_{3}$ & 500 & $\mathrm{O}_{2}$ & - & $\begin{array}{l}900 \\
\text { dec. } \\
\mathrm{Na}_{3} \mathrm{Pu} \mathrm{V}_{4} \\
1000\end{array}$ & Pure & $\begin{array}{l}\text { Tetragonal } \\
\mathrm{I} 4 / \mathrm{m}\end{array}$ & $\begin{array}{l}a=7.449 \pm 0.005 \\
c=4.590 \pm 0.005\end{array}$ & [161] & \\
\hline $\mathrm{Na}_{8} \mathrm{Pu}^{\mathrm{VI}_{\mathrm{O}}}$ & 500 & $o_{2}$ & - & $\begin{array}{l}750 \\
\text { dec. } \\
\text { B- Na } \mathrm{Nu}_{\mathrm{Pu}} \mathrm{VI}_{5}\end{array}$ & Pure & Hexagonal & $\begin{array}{l}a=5.56 \\
c=15.9\end{array}$ & $\begin{array}{l}{[160]} \\
{[161]}\end{array}$ & \\
\hline $\mathrm{Na}_{3} \mathrm{Pu}^{\mathrm{V}} \mathrm{O}_{4}$ & 900 & $a_{2}$ & - & $\begin{array}{l}1000 \\
\text { dec. } \\
\mathrm{PuO}_{2}\end{array}$ & Pure & & - & $\begin{array}{l}{[160]} \\
{[162]}\end{array}$ & 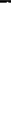 \\
\hline $\mathrm{Ca}_{\mathrm{A}_{3}} \mathrm{pu}_{\mathrm{O}} \mathrm{n}_{\mathrm{O}_{6}}$ & $950-1050$ & $\mathrm{o}_{2}$ & - & $\begin{array}{l}>1000 \\
\text { dec. }\end{array}$ & Impure & - & - & $\begin{array}{l}{[141]} \\
{[163]}\end{array}$ & \\
\hline $\mathrm{St}_{3} \mathrm{Pu}^{\mathrm{VI} \mathrm{O}_{6}}$ & $900-1200$ & $\mathrm{O}_{2}$ & - & . & Pure & - & . & $\begin{array}{l}{[141]} \\
{[164]}\end{array}$ & \\
\hline $\mathrm{SrPu}^{\mathrm{VI}} \mathrm{O}_{4}$ & $900-1100$ & $o_{2}$ & - & - & Pure & $\begin{array}{l}\text { Rhombohedral } \\
\mathrm{R}_{3} \overline{\mathrm{m}} \text {, } \\
\mathrm{SrUO}_{4} \\
\text { type }\end{array}$ & $\begin{array}{l}a=6.51 \\
\alpha=35^{\circ} 41^{.}\end{array}$ & $\begin{array}{l}{[141]} \\
{[164]}\end{array}$ & \\
\hline $\mathrm{StPu}^{\mathrm{IV}} \mathrm{O}_{3}$ & 1300 & $\mathrm{H}_{2}$ & $2 \times 12 \mathrm{~h}$ & - & $\begin{array}{l}\text { Impure- } \\
\text { extract } \\
\mathrm{Ch}, \mathrm{OH}\end{array}$ & Cubic & $a=4.28 \neq 0.03$ & $\begin{array}{l}{[141]} \\
{[151]} \\
{[164]}\end{array}$ & \\
\hline $\mathrm{Ba}_{3} \mathrm{Pu}^{\mathrm{VI}} \mathrm{O}_{\mathrm{B}}$ & $800-1300$ & $\mathrm{O}_{2}$ & - & $\begin{array}{l}1400 \\
\text { dec. }\end{array}$ & Pure & $\begin{array}{l}\text { Cubic } \\
\bar{E} \overline{4} 3 \mathrm{~m}\end{array}$ & $a=8.844 \pm 0.006$ & $\begin{array}{l}{[141]} \\
{[164]}\end{array}$ & \\
\hline
\end{tabular}




\begin{tabular}{|c|c|c|c|c|c|c|c|c|c|}
\hline \multirow{2}{*}{$\begin{array}{l}\text { Formula } \\
\text { valency state } \\
\text { of metal ions }\end{array}$} & \multicolumn{5}{|c|}{ The condition of preparation and thermal stability } & \multicolumn{2}{|c|}{ Structural data } & \multirow[b]{2}{*}{ References } & \multirow[b]{2}{*}{ Note } \\
\hline & $\begin{array}{l}\text { Temperature of } \\
\text { crystal } \\
\text { formation } \\
\text { (C) }\end{array}$ & atm. & $\begin{array}{l}\text { Dwell } \\
\text { time }\end{array}$ & $\begin{array}{l}\text { Thermal } \\
\text { stability } \\
\text { limit } \\
\text { (C) }\end{array}$ & Purity & $\begin{array}{l}\text { Symmetry, } \\
\text { space group. } \\
\text { structure type }\end{array}$ & $\begin{array}{c}\text { Unit cell } \\
\text { dimensions } \\
(\AA)\end{array}$ & & \\
\hline$\alpha-\mathrm{BaPu}^{\mathrm{IV}} \mathrm{O}_{3}$ & 1200 & $\mathrm{H}_{2}$ & - & $\begin{array}{l}1300 \\
0 x .\end{array}$ & $\begin{array}{l}\text { Ethanol } \\
\text { extract }\end{array}$ & $\begin{array}{l}\text { Cubic Pm3m } \\
\text { Perovskite }\end{array}$ & $\begin{array}{l}\mathrm{a}=4.39 \\
\mathrm{a}=4.357 \pm 0.007 \\
{ }^{a_{\mathrm{I}}}=4.322 \neq 0.003 \\
\mathrm{a}_{\mathrm{bl}}=3.730 \pm 0.003\end{array}$ & $\begin{array}{l}{[151]} \\
{[164]} \\
{[165]}\end{array}$ & $\begin{array}{l}2,3 \\
2\end{array}$ \\
\hline $\mathrm{B}-\mathrm{BaPu}{ }^{\mathrm{IV}} \mathrm{O}_{3}$ & 1600 & $\mathrm{H}_{2}$ & & & $\begin{array}{c}\text { Impure } \\
\text { (?) }\end{array}$ & $\begin{array}{c}\text { Orthorhombic } \\
\text { (?) }\end{array}$ & $\begin{array}{l}a=5.795+0.004 \\
b=5.861 \pm 0.004 \\
c=5.983+0.004\end{array}$ & [165] & \\
\hline $\mathrm{BaS}_{2} \mathrm{Pu}^{\mathrm{VI} \mathrm{O}_{6}}$ & $800-1300$ & $\mathrm{O}_{2}$ & & & & & $a=8.717 \neq 0.008$ & $\begin{array}{l}{[141]} \\
{[164]}\end{array}$ & 4 \\
\hline $\mathrm{SrBa}_{2} \mathrm{Pu}^{\mathrm{VI}} \mathrm{O}_{6}$ & $800-1300$ & & & & & & $a=8.780 \div 0.002$ & & \\
\hline $\mathrm{Pu}^{\mathrm{II}} \mathrm{AlO}_{3}$ & $1100-1500$ & $\mathrm{H}_{2}$ & $2 \mathrm{~h}$ & $\begin{array}{l}\mathrm{m} \cdot \mathrm{p} . \\
1810\end{array}$ & Impure & $\begin{array}{l}\text { Orthorhombic } \\
\text { Amm } 2 \\
\text { Perovskite }\end{array}$ & $\begin{array}{l}a=3.750 \\
b=5.314 \\
c=5.350\end{array}$ & [153] & \\
\hline $\mathrm{Pu}^{\mathrm{III}} \mathrm{vo}_{3}$ & $1100-1500$ & $\mathrm{H}_{2}$ & $2 \mathrm{~h}$ & & Pure & $\begin{array}{l}\text { Orthorhombic } \\
\text { Amm } 2 \\
\text { Perovskite }\end{array}$ & $\begin{array}{l}a=5.48 \\
b=5.61 \\
c=7.78\end{array}$ & {$[151]$} & \\
\hline $\mathrm{Pu}^{\mathrm{II}} \mathrm{CrO}_{3}$ & $1100-1500$ & $\mathrm{H}_{2}$ & $2 \mathrm{~h}$ & & Pure & $\begin{array}{l}\text { Orthorhombic } \\
\text { Amm } 2 \\
\text { Perovskite }\end{array}$ & $\begin{array}{l}a=5.46 \\
b=5.51 \\
c=7.76\end{array}$ & [151] & \\
\hline
\end{tabular}




\begin{tabular}{|c|c|c|c|c|c|c|c|c|c|}
\hline $\mathrm{Pu}^{\mathrm{lll}} \mathrm{MnO}$ & $1100-1500$ & $\mathrm{H}_{2}$ & $2 \mathrm{~h}$ & & Impure & $\begin{array}{l}\text { Pseudocubic } \\
\text { Perovskite }\end{array}$ & $a=3.86$ & [151] & \\
\hline$\alpha-\mathrm{Pu}^{1 \mathrm{~V}_{\mathrm{GeO}}}$ & $\begin{array}{c}1100 \\
230-240\end{array}$ & $\begin{array}{l}\mathrm{O}_{2} \\
\mathrm{H}_{2} \mathrm{O}\end{array}$ & $\begin{array}{l}2 \times 12 \mathrm{~h} \\
5-6 d\end{array}$ & $\begin{array}{l}1150^{\circ} \text { trans. } \\
B-\mathrm{Pu}^{\mathrm{IV}} \mathrm{Ge} \mathrm{O}_{4} \\
1150^{\circ} \text { trans. } \\
B-\mathrm{Pu}^{\mathrm{IV}} \mathrm{Ge} \mathrm{O}_{4}\end{array}$ & $\begin{array}{l}\text { Pure - } \\
\text { Pure }\end{array}$ & $\begin{array}{l}\text { Tetragonal } \\
14_{1} / \mathbf{a} \\
\text { Tetragonal } \\
14{ }_{1} / \mathbf{a} \\
\text { Scheelite }\end{array}$ & $\begin{array}{l}a=5.040 \pm 0.002 \\
c=11.11 \pm 0.01 \\
a=5.043 \pm 0.009 \\
c=11.13 \pm 0.103\end{array}$ & $\begin{array}{l}{[163]} \\
{[141]}\end{array}$ & 5 \\
\hline $\mathrm{B}-\mathrm{Pu}^{\mathrm{IV}} \mathrm{GeO}_{4}$ & 1150 & $\mathrm{O}_{2}$ & - & & & $\begin{array}{l}\text { Tetragonal } \\
\text { I } 4 / \text { amd } \\
\text { Zircon }\end{array}$ & $\begin{array}{l}a=7.073 \pm 0.004 \\
c=6.499 \pm 0.003\end{array}$ & $\begin{array}{l}{[141]} \\
{[163]}\end{array}$ & 6 \\
\hline$\alpha+\mathrm{Pu}^{\mathrm{IV}} \mathrm{SiO}_{4}$ & $230-240$ & $\mathrm{H}_{2} \mathrm{O}$ & $5.6 \mathrm{~d}$ & & I mpure & $\begin{array}{l}\text { Tetragonal } \\
\text { I4/amd } \\
\text { Zircon }\end{array}$ & $\begin{array}{l}a=6.906 \pm 0.006 \\
c=6.221 \pm 0.006\end{array}$ & $\begin{array}{l}{[141]} \\
{[163]}\end{array}$ & \\
\hline $\begin{array}{l}\mathrm{B}-\left(\mathrm{U}_{0.51} \mathrm{P}_{0.5}\right) \\
\quad\left(\mathrm{Si}_{0.51} \mathrm{Ge}_{0,5}\right) \mathrm{O}_{4}\end{array}$ & $230-240$ & $\mathrm{H}_{2}$ & $5-6 d$ & & & $\begin{array}{l}\text { Tetragona] } \\
\text { [ } 4 / \text { amd } \\
\text { Zircon }\end{array}$ & $\begin{array}{l}a=6.995 \pm 0.005 \\
c=6.364 \pm 0.015\end{array}$ & {$[141]$} & \\
\hline $\mathrm{Pu}^{\mathrm{III}} \mathrm{Ta} \mathrm{V}_{\mathrm{O}_{4}}$ & 1350 & $\mathrm{H}_{2}$ & $2 \times 8 \mathrm{~h}$ & & Pure & $\begin{array}{c}\text { (?) } \\
\mathrm{LaTaO} \\
\text { type }\end{array}$ & - & {$[166]$} & \\
\hline $\mathrm{Pu}_{\mathrm{u}}^{\mathrm{III}} \mathrm{Nb} \mathrm{V}_{\mathrm{O}_{4}}$ & 1200 & $\mathrm{As}$ & $2 \times 12 \mathrm{~h}$ & & $\begin{array}{c}\text { Impure } \\
\mathrm{PuO}_{2}+ \\
\mathrm{PuO}_{2} \cdot 2 \mathrm{Nb}_{2} \mathrm{O}_{5}\end{array}$ & Monoclinic & $\begin{aligned} a & =5.46 \pm 0.002 \\
b & =11.24 \pm 0.02 \\
c & =5.17 \pm 0.02 \\
& =94^{\circ} 35^{\circ} \pm 20^{\circ}\end{aligned}$ & {$[166]$} & \\
\hline $\mathrm{PuO}_{2} \cdot 2 \mathrm{Ta}_{2} \mathrm{O}_{5}$ & $1350-1450$ & $\begin{array}{l}\mathrm{O}_{2} \\
\text { air }\end{array}$ & $\cdot 10 \mathrm{~h}$ & $\begin{array}{l}1400^{\circ} \\
\text { dec. }\end{array}$ & & Tetragonal & $\begin{array}{l}a=7.654 \pm 0.005 \\
c=7.731 \pm 0.005\end{array}$ & [167] & \\
\hline
\end{tabular}




\begin{tabular}{|c|c|c|c|c|c|c|c|c|}
\hline \multirow{2}{*}{$\begin{array}{l}\text { Formula } \\
\text { valency state } \\
\text { of metal ions }\end{array}$} & \multicolumn{4}{|c|}{ The condition of preparation and thermal stability } & \multicolumn{2}{|c|}{ Structural data } & \multirow[b]{2}{*}{ References } & \multirow[b]{2}{*}{ Notes } \\
\hline & $\begin{array}{l}\text { Temperature of } \\
\text { crystal } \\
\text { formation } \\
\text { ('C) }\end{array}$ & atm. & $\begin{array}{l}\text { Dwell } \\
\text { time }\end{array}$ & $\begin{array}{l}\text { Thermal } \\
\text { stability } \\
\text { limit } \\
\text { ("C) }\end{array}$ & $\begin{array}{l}\text { Symmetry, } \\
\text { space group, } \\
\text { structure type }\end{array}$ & $\begin{array}{l}\text { Unit cell } \\
\text { dimensions } \\
(\dot{A})\end{array}$ & & \\
\hline $\mathrm{PuO}_{2} \cdot 2 \mathrm{Nb}_{2} \mathrm{O}_{5}$ & $1200-1250$ & $\begin{array}{l}\mathrm{O}_{2} \\
\text { air }\end{array}$ & $>10 \mathrm{~h}$ & & Tetragonal & $\begin{array}{l}a=7.760 \pm 0.002 \\
c=7.792 \pm 0.006\end{array}$ & [167] & \\
\hline $\mathrm{PuO}_{2} \cdot \mathrm{NbO}$ & $1050-1150$ & $\mathrm{O}_{2}$ & $\begin{array}{l}\text { Very } \\
\text { short }\end{array}$ & & & Unknown structure & [167] & \\
\hline $\begin{array}{l}\mathrm{Ba}_{2} \mathrm{Pu}^{\mathrm{III}} \\
\mathrm{Ta}_{2} \mathrm{~V}_{6}\end{array}$ & $1200-1300$ & $H_{2}$ & & & $\begin{array}{l}\text { Cubic } \\
\text { Perovskite }\end{array}$ & $a=8.59 \pm 0.07$ & [167] & \\
\hline 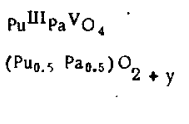 & 900 & $\mathrm{H}_{2}$ & & & $\begin{array}{l}\text { Cubic } \\
\text { Fm3m } \\
\text { Fluorite }\end{array}$ & $a=5.443 \neq 0.002$ & $\begin{array}{l}{[163]} \\
{[166]}\end{array}$ & 7 \\
\hline $\begin{array}{l}\mathrm{Ba}_{2} \mathrm{P}_{\mathrm{L}} \mathrm{III} \\
\mathrm{Pa} \mathrm{V}_{\mathrm{O}_{6}}\end{array}$ & $1350-1400$ & $\mathrm{H}_{2}$ & & & $\begin{array}{l}\text { Cubic } \\
\text { Perovskite }\end{array}$ & $a=8.748 \div 0.006$ & $\begin{array}{l}{[164]} \\
{[166]}\end{array}$ & 8 \\
\hline
\end{tabular}

${ }^{a}$ Thermal stability abbreviations:

ox. = oxidation

trans. = phase transition

m.p. = melting point

Notes:

dec. = decomposition (product given)

1. Possibly distorted $\mathrm{NaCl}$ structure.

2. al refers to a product prepared at $900^{\circ} \mathrm{C}$, a $a_{11}$ to a product prepared at $1100^{\circ} \mathrm{C}$.

3. Chackraburtty et al. [165] noted the possibility of the existence of $\mathrm{Ba}_{\mathrm{X}} \mathrm{Pu} \mathrm{VI}_{\mathrm{O}_{3}}$, where $\mathrm{x}_{1}$ is very small.

4. The lattice parameter is dependent upon the $\mathrm{Ba} / \mathrm{Sr}$ ratio [164] and obeys Végard's Law upto 2.25 mole ratio of the $\mathrm{Sr}$ ion.

5. Preparation by annealing of corresponding oxides at $1100^{\circ} \mathrm{C}$ in flowing oxygen or by means of hydrothermal method.

6. This compound is formed during hydrothernal preparation of $\alpha-\mathrm{PuGeO}_{4}$.

7. The formula is limited by condition $0<y<u .5$.

8. The value of the lattice parameter shows that redox equilibrium $\mathrm{Ba}_{2} \mathrm{Pu}^{\mathrm{IIl}} \mathrm{Pa}_{\mathrm{a}} \mathrm{v}_{6}=\mathrm{Ba}_{2} \mathrm{Pu}^{\mathrm{IV}} \mathrm{Pa} \mathrm{V}_{\mathrm{O}_{6}}$ occurs. 
Végard's Law, were slightly substoichiometric (reported in $[143,144])$. The somewhat unexpected shape of the liquidus curve found by Freshley and Mattys [157] (Fig. 26) may also be due to reduction.

\subsection{4. $\mathrm{UO}_{2}-\mathrm{PuO}_{2}$}

This system is treated in detail in Section III of this report.

\subsection{More complicated systems}

$$
\text { 1.3.1. } \mathrm{Eu}_{2} \mathrm{O}_{3}-\mathrm{PuO}_{2}
$$

Haug and Weigel [158] have studied the lattice parameters of the $\mathrm{EuO}_{1.5}-\mathrm{PuO}_{2}$ binary system (Table XVI, Fig. 27). The complicated variation with concentration is very similar to that in the $\mathrm{UO}_{2}$-rare earth oxide systems published by Rundle et al. [159]. There was some evidence that $\mathrm{Pu}(\mathrm{IV})$ was oxidized to a higher valency between 15 and $42 \% \mathrm{EuO}_{1.5}$, but this suggestion remains to be confirmed.

The fluorite-type lattice of the solution above 42 mole $\% \mathrm{EuO}_{1.5}$. appeared to be considerably distorted, while above 60 mole $\% \mathrm{EuO}_{1.5}$ transition to the body-centred cubic structure was indicated.

\section{TERNARY AND QUATERNARY PLUTONIUM-METAL-OXIDES}

The thermochemical properties of this group of the plutonium compounds have not been generally studied. In Table XVII the available basic physico-chemical properties are shown. It will be appreciated that many of these mixed oxides involve quinque- or sexavalent plutonium. 


\section{R E F E R E N C E S}

[1] INTERNA TIONAL A TOMIC ENERGY AGENCY, Thermodynamic and transport properties of uranium dioxide and related phases, IAEA, Vienna (1965).

[2] MOONEY, R.C.L., ZACHARIASEN, W.H., The Transuranium Elements, National Nuclear Energy Series, Div. IV-14B, McGraw Hill, New York (1949) 1442.

[3] ZACHARIASEN, W.H., Acta crystallogr. 2 (1949) 388.

[4] WESTRUM, E.F., Jr., The Transuranium Elements, National Nuclear Energy Series, Div. IV-14B, McGraw Hill, New York (1949) 936.

[5] HOLLEY, C.E., MULFORD, R.N.R., HUBER, E.J., HEAD, E.L., ElLINGER, F. H., BJORKLUND, C. W., Proc, 2nd UN Int. Conf. PUAE 6 (1958) 215.

[6] AKIMOTO, Y., Rpt UCRL-9093 (1960).

[7] SKAVDAHL, R.E., Rpt HW-75914 (1962).

[8] FORBES, R.L., FUHRMAN, N., ANDERSEN, J., TAYLOR, K., Rpt UNC-5144 (1966).

[9] DEAN, G., Proc. 3rd Int. Conf. on Plutonium, London, (1965).

[10] MULFORD, R.N.R., ELLINGER, F.H., JOHNSON, K.A., J. nucl. Mater. 17 (1965) 324.

[11] ANSELIN, F., DEAN, G., LORENZELLI, R., PASCARD, R., Carbides in Nuclear Energy, Macmillan, London (1964) 113.

[12] POTTER, P.E., private communication from A.E.R.E., Harwell.

[13] GARDNER, E.R., MARKIN, T.L., STREET, R.S., J. inorg. nucl. Chem. 27 (1965) 541.

[14] CHIKALLA, T.D., Rpt HW-71887 (1961).

[15] RUSSELL, L.E., BRETT, N.H., HARRISON, J.D.L., RILEY, B.F.J., in Plutonium 1960, Cleaver-Hume Press, London (1961) 489.

[16] ROBERTS, L.E.J., RUSSELl, L.E., ADWICK, A.G., WALTER, A.J., RAND, M.H., Proc. 2nd UN Int. Conf. PUAE 28 (1958) 215.

[17] SKAVDAHL, R.E., Rpt HW-76301 (1963).

[18] SKAVDAHL, R.E.. CHIKALLA, T.D., Rpt HW-81601 (1964).

[19] Plutonium Recycle Program Annual Report, 1961, Rpt HW-70000 (1962).

[20] CHIKALLA, T.D., MCNEILLY, C.E., SKAVDAHL, R.E., J. nucl. Mater. 12 (1964) 131.

[21] PASCARD, R., report to this panel.

[22] OHSE, R.W., report to this panel.

[23] SARI, C., BENEDICT, U., BLANK, H., report to this panel.

[24] DRUMMOND, J.L., WELCH, G.A., J. chem. Soc. (1957) 4781.

[25] WA TERBURY, G.R., DOUGLASS, R.M., METZ, C.F., Analyt. Chem. 33 (1961) 1018.

[26] JACKSON, E.E., RAND, M.H., Rpt AERE-R-3636 (1963).

[27] BJORKLUND, C.W., STARITSKY, E., Rpt LA-1869 (1954).

[28] ANDERSON, H.J., Rpt HW-76303 (1963).

[29] BURNHAM, J.B., Rpt BNWL-91 (1965).

[30] Use of Plutonium as Fuel in Nuclear Reactors, Rpt EURAEC-790 (1963).

[31] DRUMMOND, J.L., WELCH, G.A., J. chem. Soc. (1956) 2565.

[32] FRANCIS, K.E., SOWDEN, R.G., Rpt AERE-R-2939 (1959).

[33] Correlation between the Methods of Precipitation of Plutonium Salts and Sintering their Oxides, Rpt EURAEC-705 (1963).

[34] Use of Plutonium as Fuel in Nuclear Reactors, Rpt EURAEC-176 (1961).

[35] Use of Plutonium as Fuel in Nuclear Reactors, Rpt EURAEC-408 (1962).

[36] Use of Plutonium as Fuel in Nuclear Reactors, Rpt EURAEC-1504 (1965).

[37] PUECHL, K.H., Rpt NUMEC-P-102 (1962).

[38] PUECHL, K.H., Rpt NUMEC-P-103 (1963).

[39] PUECHL, K.H., Rpt NUMEC-P-105 (1963).

[40] FACER, J.F., HARMON, K.M., Rpt HW-31186 (1954). 
[41] HARMON, K.M., REAS, W.H., Rpt HW-49597A (1957).

[42] DAWSON, J.K., ELLIOTT, R. M., Rpt AERE-C/R-1207 (1957).

[43] RAO, G.S., SUBRAMANIAN, M.S., WELCH, G.A., J. inorg. nucl. Chem. 25 (1963) 1293.

[44] LEARY, J.A., MARAMAN, W.J., SCHONFELD, F. W., Rpt LA(MS)-3107 (1964).

[45] JENKINS, I.L., WATERMAN, M.J., J. inorg. nucl. Chem. 26 (1964) 131.

[46] PUECHL, K.H., Rpt NUMEC-P-60 (1961).

[47] PUECHL, K.H., Rpt NUMEC-P-80 (1962).

[48] PUECHL, K.H., Rpt NUMEC-P-90 (1962).

[49] PUECHL, K.H., Rpt NUMEC-2389-2 (1964).

[50] LEARY, J.A., Rpt LA-1913 (1954).

[51] LEARY, J.A., MORGAN, A.N., MARAMAN, W.J., Ind. Engng Chem. ind. (int,) Edn 5127 (1959).

[52] MAINLAND, E.W., ORTH, D.A., FIELD, E.L., RADKE, J.H., Ind. Engng Chem, ind. (int.) Edn $53 \quad 685$ (1961).

[53] PUECHL, K.H., Rpt NUMEC-P-104 (1963).

[54] BENEDICT, G.E., HARMON, K.M., JANSEN, G., Jr., MUDGE, L.K., SCOTT, F.A., Rpt HW-SA-2915 (1963).

[55] BREWER, L., Chem. Rev. 52 (1953) 1.

[56] KATZ, J.J., GRUEN, D.M., J. Am, chem. Soc. 71, (1949) 2106.

[57] BAGNALL, K.W., LAIDLER, J.B., J. chem. Soc. (1964) 2693.

[58] TEMPLETON, D.H., DAUBEN, C.H., Rpt UCRL-1886 (1952).

[59] RAND, M.H., FOX, A.C., STREET, R.S., Nature, Lond, 195 (1962) 567.

[60] GRIFFEN, C.S, MENDELSSOHN, K., KING, E., LEE, J.A., RAND, M.H., STREET, R.S., "Self-irradiation damage in transuranic elements and compounds", Proc. 3rd International Conference on Plutonium, London, 1965.

[61] ATLAS, L.M., SCHLEMAN, G.J., READEY, D. W., J. Am. Ceram. Soc. 49 (1966) 624.

[62] MULFORD, R.N.R., LAMAR, L.E., "The volatility of plutonium oxide", Plutonium 1960, Cleaver-Hume Press, London (1961) 411.

[63] ACKERMANN, R.J., FAIRCLOTH, R.L., RAND, M.H., J. phys, Chem., Ithaca 70 (1966) 3698.

[64] LIVEY, D. T., FESCHOTTE, P., Atom. Energy Rev. 4, Special Issue 1 (1966) 53.

[65] RILEY, B.F.J., private communication from A.E.R.E., Harwell (1964).

[66] MARKIN, T.L., RAND, M.H., in Thermodynamics I, IAEA, Vienna (1966) 145.

[67] McNEILLY, C.E., J. nucl. Mater. 11 (1964) 53.

[68] BRETT, N.H., RUSSELl, L. E., in Plutonium 1960, Cleaver-Hume Press, London (1961) 397.

[69] LE BLANC, J.M., ANDRIESSEN, H., Rpt EURAEC-434.

[70] RAND, M.H., A tom. Energy Rev. 4, Special Issue 1 (1966) 7.

[71] HYDE, B.G., BEVAN, D. J.M., EYRING, L., Phil. Trans R. Soc. A 259 (1966) 583.

[72] SAWYER, J.O., HYDE, B.G., EYRING, L., Bull. Soc. chim. Fr. 4 (1965) 1190.

[73] BEVAN, D.J.M., KORDIS, J., J. inorg. nucl. Chem. 26 (1964) 1509.

[74] BEVAN, D.J.M., J. inorg. nucl. Chem. 1 (1955) 49.

[75] CHAPIN, D.S., FINN, M.C., HONIG, J.M.., Proc. 4th Conf. Rare Earth Research, Gorcon \& Breach, New York (1966) 607.

[76] RAND, M.H., in Thermodynamics II, IAEA, Vienna (1966) 603.

[77] OET TING, F.L., J. inorg. nucl. Chem. 27 (1965) 2151.

[78] KINCHIN, L., PEASE, R., Rep. Prog. Phys, 18 (1955) 1.

[79] OLSEN, C.E., ELLIOT, R.O., SANDENAW, T.A., in Radiation Damage in Reactor Materials, IAEA, Vlenna (1963) 35.

[80] SANDENAW, T.A., J. nucl. Mater. 10 (1963) 165.

[81] OSBORNE, D.W., WESTRUM, E.F., J. chem. Phys. 21 (1953) 1884.

[82] JONES, W.M., GORDON, J., LONG, E.A., J. chem. Phys. 20 (1952) 695.

[83] WESTRUM, E.F., HATCHER, J.B., OSBORNE, D.W., J. chem. Phys., 21 (1953) 419.

[84] NAGELS, P., private communication from Studvencentrum voor Kemenergie, Mol-Donk (1966).

[85] WILliS, B. T.M., Proc. R. Soc. A274 (1963) 134.

[86] ROOF, R.B., J. nucl. Mater. 2 (1960) 39.

[87] TAYLOR, J.C., LOASBY, R.G., DEAN, D.J., LINFORD, P.F., Proc. 3rd Int. Conf, on Plutonium, London, 1965.

[88] LEE, J.A., private communication from A.E.R.E., Harwell (1966). 
[89] SPARKS, J.T., KOMOTO, T.T., Rpt UCRL-14360 (1965) 47.

[90] DAWSON, J.K., J. chem. Soc. (1952) 1882.

[91] WESTRUM, E.F., GRØNVOLD, F., in Thermodynamics of Nuclear Materials, IAEA, Vienna (1962) 3.

[92] Brussels EURAEC Report, Rpt EURAEC-307 (1960).

[93] KING, E.G., CHRISTENSEN, A.U., U.S. Bureau Mines Report Invest. No. 5789 (1961).

[94] PANKRATZ, L.B., KELLEY, K. K., U.S. Bureau Mines Report Invest. No. 6248 (1963).

[95] KUZNETSOV, R.A., REZUKHINA, T.N., Zh. fiz, khim. 34 (1960) 2467; tbid. 35 (1961) 956; Russ. J. phys. Chem. 34 (1960) 1164 ; ibid. 35 (1961) 470.

[96] KING, E.G., WELLER, W.W., PANKRATZ, L. B., U.S. Bureau Mines Report Invest. No. 5857 (1961).

[97] PANKRATZ, L.B., U.S. Bureau Mines Report Invest. No. 6781 (1966).

[98] PANKRATZ, L.B., KING, E. G., KELLEY, K. K., U.S. Bureau Mines Report Invest. No. 6033 (1962).

[99] PANKRATZ, L.B., KING, E. G., U.S. Bureau Mines Report Invest. No. 6175 (1963).

[100] POPOV, M.M., IVANOV, M.l., Atomn. Energ. 2 (1957) 360 ; Soviet. J. Atom. Energy 2 (1957) 439.

[101] HOLLEY, C.E., MULFORD, R.N.R., HUBER, E.J., HEAD, E.L., BJORKLUND, C.W., Proc. 2nd UN Int. Conf. PUAE 61 (1958) 215.

[102] MARKIN, T.L., BONES, R.]., GARDNER, E.R., private communication (see also Ref. [66]).

[103] ATLAS, L.M., SCHLEHMAN, G.J., in Thermodynamics II, IAEA, Vienna (1966) 407.

[104] BAIRIOT, H., VANHELLEMONT, G., private communication from BelgoNucléaire, Brussels.

[105] CHIKALLA, T.D., private communication from Battelle North-West, 1966.

[106] STULL, D.R., SINKE, G.C., Thermodynamic Properties of the Elements, American Chemical Society, Washington, D.C. (1956).

[107] MULFORD, R.N.R., ELLINGER, F.H., JOHNSON, K.A., J. nucl. Mater. 17 (1965) 324.

[108] PHIPPS, T.E., SEARS, G.W., SIMPSON, O.C., J. chem. Phys. 18 (1950) 724.

[109] PARDUE, W.M., KELLER, D.L., J. Am. Ceram. Soc. 47 (1964) 610 .

[110] PAPROCKI, S.J., KELLER, D.L., ALEXANDER, C.A., PARDUE, W.M., Rpt BMI-1591 (1962).

[111] OHSE, R.W., private communication.

[112] MULFORD, R.N.R., in Thermodynamics I, IAEA, Vienna (1966) 231.

[113] ACKERMANN, R.J., RAUH, E.G. THORN, R.J., CANNON, M.C., J. phys. Chem., Ithaca 67 (1961) 762 .

[114] ACKERMANN, R.J., GILLES, P.W., THORN, R.J., J. chem. Phys. 25 (1956) 1089.

[115] DE MARIA, G., BURNS, R.P., DROWART, J., INGHRAM, M., J. chem. Phys. 32 (1960) 1373.

[116] ACKERMANN, R.J., RAUH, E.G., CHANDRASEKHARAIAH, M.S., Argonne National Lab. Rpt ANL-7048 (1965).

[117] ACKERMANN, R.J., FAIRCLOTH, R.L., RAUH, E.G., THORN, R.J., J. inorg. nucl. Chem. 28 (1966) 111.

[118] ACKERMANN, R.J., THORN, R.J., in Thermodynamics I, Vienna (1966) 243.

[119] BLANK, H., BENEDICT, U., SARI, C., private communication from E.I.T., Karlsruhe.

[120] MARKIN, T.L., STREET, R.S., private communication from A.E.R.E., Harwell (1966).

[121] DEAN, G., PASCARD, R., report to this panel.

[122] MARKIN, T.L., McIVER, E.J., Proc. 3rd Int. Conf. on Plutonium, London, 1965.

[123] HENRION, R., DIELS, P., report to this panel.

[124] BRETT, N.H., FOX, A.C., J. inorg. nucl. Chem. 28 (1966) 1191.

[125] CHICALLA, T.D. in Plutonium 1960, Cleaver-Hume Press, London (1961) 455.

[126] BRETT, N.H., RUSSELL, L.E., Trans. Br. Ceram. Soc. 62 (1963) 97.

[127] MARKIN, T.L.. STREET, R.S., IAEA panel paper (to be published in J. inorg. nucl. Chem.).

[128] CHIKALLA, T.D., Rpt HW-69832 (1961).

[129] PIJANOWSKI, S.W., DELUCA, L.S., Rpt KAPL-1957 (1960).

[130] LYON, W.L., BAILY, W.E., Trans. Am. nucl. Soc. $\underline{8}$ (1965) 376.

[131] LYON, W.L.. BAILY, W.E., Rpt GEAP-4878 (1965).

[132] EPSTEN, L.F., J. nucl. Mater. (to be published).

[133] GRONVOLD, F., J. inorg. nucl. Chem. 1 (1955) 357.

[134] COHEN, I., BERMAN, R.M., J. nucl. Mater, 18 (1966) 77.

[135] MARKIN, T.L., ROBERTS, L.E.J., Thermodynamics of NuclearMaterials, IAEA, Vienna (1962) 693.

[136] MARKIN, T.L., ROBERTS, L.E.J., Thermodynamics of ceramic systems, (to be published in Trans. Br. Ceram. Soc.). 
[137] MARKIN, T.L., private communication from A.E.R. E., Harwell (1966).

[138] AITKEN, E.A., EDWARDS, J.A., JOSEPH, R.A., J. phys. Chem. 70 (1966) 1084.

[139] AITKEN, E.A., JOSEPH, R.A., J. phys. Chem. 70 (1966) 1090.

[140] RAND, M. H., private communication.

[141] KELLER, C., Kernforschungszentrum Rpt KFK-225 (1964).

[142] HOUGH, A., MARPLES, J.A.C., J. nucl. Mater. 15 (1965) 298.

[143] DAYTON, R.W., PAPROCKI, S.J., Rpt BMI-1707 (Del)(1964).

[144] DAYTON, R.W., PAPROCKI, S.J.; Rpt BMI-1721 (Del) (1965).

[145] DAYTON, R.W., PAPROCKI, S.J., Rpt BMI-1723 (Del) (1965).

[146] DAYTON, R.W., PAPROCKI, S.J., Rpt BMI-1727 (Del) (1965).

[147] DAYTON, R.W., PAPROCKI, S.J., Rpt BMI-1733 (Del) (1965).

[148] CARROLL, D.F., J. Am. Ceram. Soc. 47 (1964) 650.

[149] CARROLL, D.F., Rpt HW-81601, 21.

[150] CARROLL, D.F., Rpt HW-76303 (1963) 21.

[151] RUSSELL, L.E., HARRISON, J.D.L., BRETT, N.H., J. nucl. Mater. 2 (1960) 310.

[152] McEWEN, L.H., Ed., Rpt HW-65078 (1960).

[153] RUNNALLS, O.J.C., Proc. 3rd Int. Conf. on Plutonium, London, 1965.

[154] MULFORD, R.N.R., ELLINGER, F.H., J, phys. Chem., Ithaca 62 (1958) 1466.

[155] CARROLL, D.F., J. Am. Ceram. Soc. 46 (1963) 194.

[156] CARROLL, D.F., Rpt HW-69305 (1961).

[157] FRESHLEY, M.D., MATTYS, H.M., Rpt HW-76300 (1962) 26.

[158] HAUG, H. WEIGEL, F., J. nucl. Mater. 9 (1963) 360.

[159] RUNDLE, R.E., BAENZINGER, N.C., WILSON, A.S., MCDONALD, R.A., J. Am. Chem. Soc. 70 (1948) 99.

[160] KOCH, L., Dissertation, Technische Hochschule, Karlsruhe (1963), Rpt KFK-196 (1964).

[161] KELLER, C., KOCH, L., WALTER, K.H., J. inorg. nucl. Chem. 27 (1965) 1205.

[162] KELLER, C., KOCH, L., WALTER, K.H., J. inorg. nucl. Chem. $\overline{27}$ (1965) 1225.

[163] KELLER, C., Nukleonik $\underline{5}$ (1963) 41.

[164] KELLER, C., Nukleonik $\overline{4}$ (1962) 271.

[165] CHACKRABURTTY, D.M., JAYADEVA, U.C., SIVARAMAKRISHNAN, C.K., Acta Crystallogr. 16 (1958) 1060 .

[166] KELLER, C., WALTER, K.H., J. inorg. nucl. Chem. 27 (1965) 1253.

[167] KELLER, C., J. inorg. nucl. Chem. 27 (1965) 1233. 


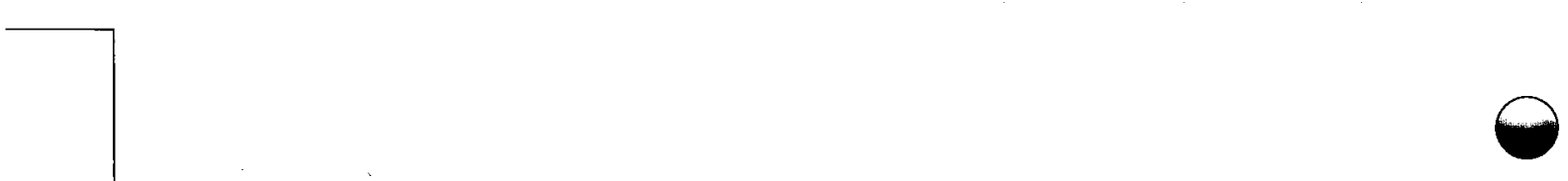

$\bullet$

$\bullet$ 


\section{LIST OF PARTICIPANTS}

The members attending the Panel Meeting, held on 24-28 October, 1966, at the Headquarters of the International Atomic Energy Agency in Vienna to assess the thermodynamic properties of the plutonium-oxygen and uranium-plutonium-oxygen systems, were:

RAND, M. H.

(Chairman)

ACHACHINSKY, V. V.

ACKERMANN, R. J.

BAIRIOT, $\mathrm{H}$.

BLANK, H.

HOLLEY, C. E., Jr.

JAKE $\check{S}, D$.

KOIZUMI, M.

KOLAR, D.

LAPAGE, R.

MARKIN, T.L.
Atomic Energy Research Establishment, Harwell, Didcot, Berks., United Kingdom

State Committee for the Utilization of Atomic Energy, USSR

Argonne National Laboratory, Argonne, I11., United States of America

BelgoNucléaire, Brussels, Belgium

Euratom, Karlsruhe, Federal Republic of Germany University of California, Los Alamos Scientific Laboratory, Los Alamos, N.Mex., United States of America

The Nuclear Research Institute of the Czechoslovak Academy of Sciences, Rež, Czechoslovakia

Atomic Fuels Corporation, Tokai-mura, Japan

Jožef Stefan Nuclear Institute, Ljubljana, Yugoslavia

Atomic Energy Establishment, Aldermaston, Berks., United Kingdom

Atomic Energy Research Establishment, Harwell, Didcot, Berks., United Kingdom 
MULFORD, R. N.R.

NAGELS, P.

OHSE, R.W.

PASCARD, R.

RAMANIAH, M. V.

STOLL, W.

SECRETARIAT

Scientific Secretary

Editor
University of California, Los Alamos Scientific Laboratory, Los Alamos, N. Mex., United States of America

Centre d'étude de 1 'énergie nucléaire, Mol-Donk, Belgium

Euratom,

Karlsruhe, Federal Republic of Germany

Centre d'études nucléaires de

Fontenay-aux-Roses,

Seine, France

Atomic Energy Establishment Trombay, India

ALKEM, Leopoldshafen, Federal Republic of Germany

HARA, R.

Division of Research and Laboratories

FREEMAN, S. M.

Division of Scientific and

Technical Information 


\section{REPORTS SUBMITTED TO THE PANEL}

The following reports were submitted to the Panel, and the assessment contained in this publication is based on these reports and discussions held among the Panel members:

ACKERMANN, R.J.

BAIRIOT, $\mathrm{H}$.

JAKE ̌̀, D.

HARIHARAN, A. V., and

RAMANIAH, M. V.

KOIZUMI, M., KANEKO, H. , and AKUTSU, $\mathrm{H}$.

MARKIN, T. L.

MULFORD, R. N. R., and HOLLEY, C. E., Jr.

NAGELS, P.

OHSE, R.W.
A critical thermodynamic appraisal of the vaporization behaviour of the $\mathrm{PuO}_{2-\mathrm{x}}$ phase

Report on work carried out by $P$. Henrion and P. Wiels on mixed ( $\mathrm{U}, \mathrm{Pu}$ ) oxides

The binary system of plutonium dioxide and ternary and quarternary plutonium-metal oxides

Preparation of plutonium oxides: a literature survey

Formation of $\alpha \mathrm{Pu}_{2} \mathrm{O}_{3}$ from $\mathrm{PuO}_{2}-\mathrm{UO}_{2}$ solid solution during sintering in $\mathrm{H}_{2}$ gas atmosphere

1. The $\mathrm{Pu}-\mathrm{O}$ phase diagram;

2. Thermodynamic data for plutonium oxides;

3. The U-Pu-O phase diagram;

4. Thermodynamic data for $(\mathrm{U}, \mathrm{Pu})$ oxides

Thermodynamic properties of plutonium oxides

Heat capacities of the actinide dioxides

Preliminary report on vapour pressure studies of plutonium oxide with special consideration of the hypostoichiometric range 
PASCARD, R.

SARI, C., BENEDICT, U., and BLANK, $\mathrm{H}$.
1. On the ternary diagram uraniumplutonium-oxygen;

2. Vapour pressure of $\mathrm{PuO}_{2}$;

3. Vapour pressure of plutonium and uranium mixed oxides

Preliminary results of an investigation on phase relations in the $\mathrm{U}-\mathrm{Pu}-\mathrm{O}$ diagram 


\section{IAEA SALES AGENTS}

Orders for Agency publications can be placed with your bookseller or any of our sales agents listed jelow :

A R G EN TINA

Comisión Nacional de

Energía A tómica

Avenida del Libertador

General San Martin 8250

Buenos Aires - Suc. 29

A UST R A L I A

Hunter Publications,

23 McKillop Street

Melbourne, C.1

A UST R I A

Georg Fromme \& Co.

Spengergasse 39

$A=1050$, Vienna V

B E L G I U M

Office international de librairie

30, avenue Marnix

Brussels 5

B R A Z I L

Livraria Kosmos Editora

Rua do Rosario, 135-137

Rio de Janeiro

Agencia Expoente Oscar M. Silva

Rua Xavier de Toledo, 140-10 Andar

(Caixa Postal No. 5.614)

São Paulo

\section{BYELORUSSIAN SOVIET SOCIA LIST}

REPUBLIC

See under USSR

CANADA

The Queen's Printer

Ottawa. Ontario

CHINA (Taiwan)

Books and Scientific Supplies

Service, Ltd.,

P.O. Box 83

Taipe i

CZECHOSLOVAK SOCIALIST REPUBLIC

S.N.T.L.

Spolena 51

Nové Mésto

Prague 1

DE NMA R K

Ejnar Munksgaard Ltd.

6 Nörregade

Copenhagen $\mathrm{K}$
F IN L A N D

Akateeminen Kirjakauppa

Keskuskatu 2

Helsinki

F R A N C E

Office international de

documentation et librairie

48, rue Gay-Lussac

F-75, Paris $5^{e}$

GERMANY . Federal Republic of

R. Oldenbourg

Rosenheimer Strasse 145

8 Munich 8

H U N G A R Y

Kultura

Hungarian Trading Co, for Books and Newspapers

P.O.B. 149

Budapest 62

I S R A E $\mathbf{L}$

Heiliger and Co.

3 Nathan Strauss Street

Jerusalem

I T A L Y

Agenzia Editoriale Internazionale

Organizzazioni Universali (A.E.I.O.U.)

Via Meravigli 16

Milan

J A P A N

Maruzen Company Ltd.

6. Tori Nichome

Nihonbashi

(P.O. Box 605)

Tokyo Central

M E X I C O

Librería Internacional

Av. Sonora 206

Mexico 11, D.F.

NETHERLAN DS

N.V. Martinus Nijhoff

Lange Voorhout 9

The Hague

\section{NEW ZEALA N D}

Whitcombe \& Tombs, Ltd.

G.P.O. Box 1894

Wellington, C.1 


\section{NORWA Y}

Johan Grundt Tanum

Karl Johans gate 43

Oslo

PAKIS T A N

Karachi Education Society

Haroon Chambers

South Napier Road

(P.O. Box No. 4866)

Karachi 2

POLAND

Ósrodek Rozpowszechniana

Wydawnictw Naukowych

Polska Akademia Nauk

Palac Kultury i Nauki

Warsaw

ROM A N I A

Cartimex

Rue A. Briand 14-18

Bucarest

\section{SOUTH AFRICA}

Van Schaik's Bookstore (Pty) Ltd.

Libri Building

Church Street

(P.O. Box 724)

Pretoria

SPA I N

Librería Bosch

Ronda de la Universidad 11

Barcelona

$S W E D E N$

C.E. Fritzes Kungl. Hovbokhandel

Fredsgatan 2

Stockholm 16

\author{
SWITZER LA N D \\ Librairie Payot \\ Rue Grenus 6 \\ 1211 Geneva 11 \\ TURK E Y \\ Librairie Hachette \\ 469, Istiklâl Caddesi \\ Beyoğlu, Istanbul \\ UKRAINIAN SOVIET SOCIAI IST \\ REPUBLIC \\ See under USSR \\ UNION OF SOVIET SOCIALIST \\ REPUBLICS \\ Mezhdunarodnaya Kniga \\ Smolenskaya-Sennaya 32-34 \\ Moscow G-200 \\ UNITED KINGDOM OF GREAT \\ BRITAIN AND NORTHERN IRELAND \\ Her Majesty's Stationery Office \\ P.O. Box 569 \\ Lond on, S.E.1 \\ UNITED STA TES OF A MERICA \\ National Agency for \\ International Publications, Inc. \\ 317 East 34th Street \\ New York, N.Y. 10016 \\ VEN E Z UELA \\ Sr. Braulio Gabriel Chacares \\ Gobernador a Candilito 37 \\ Santa Rosalía \\ (Apartado Postal 8092) \\ Caracas D.F. \\ Y U G OSLA V IA \\ Jugoslovenska Knjiga \\ Terazije 27 \\ Belgrade
}

IAEA publications can also be purchased retail at the United Nations Bookshop at United Nations Headquarters, New York, at the news-stand at the Agency's Headquarters, Vienna, and at most conferences, symposia and seminars organized by the Agency.

In order to facilitate the distribution of its publications, the Agency is prepared to accept payment in UNESCO coupons or in local currencies.

Orders and inquiries from countries where sales agents have not yet been appointed may be sent to:

Distribution and Sales Group, International Atomic Energy Agency, Kärntner Ring 11, A-1010, Vienna I, Austria 